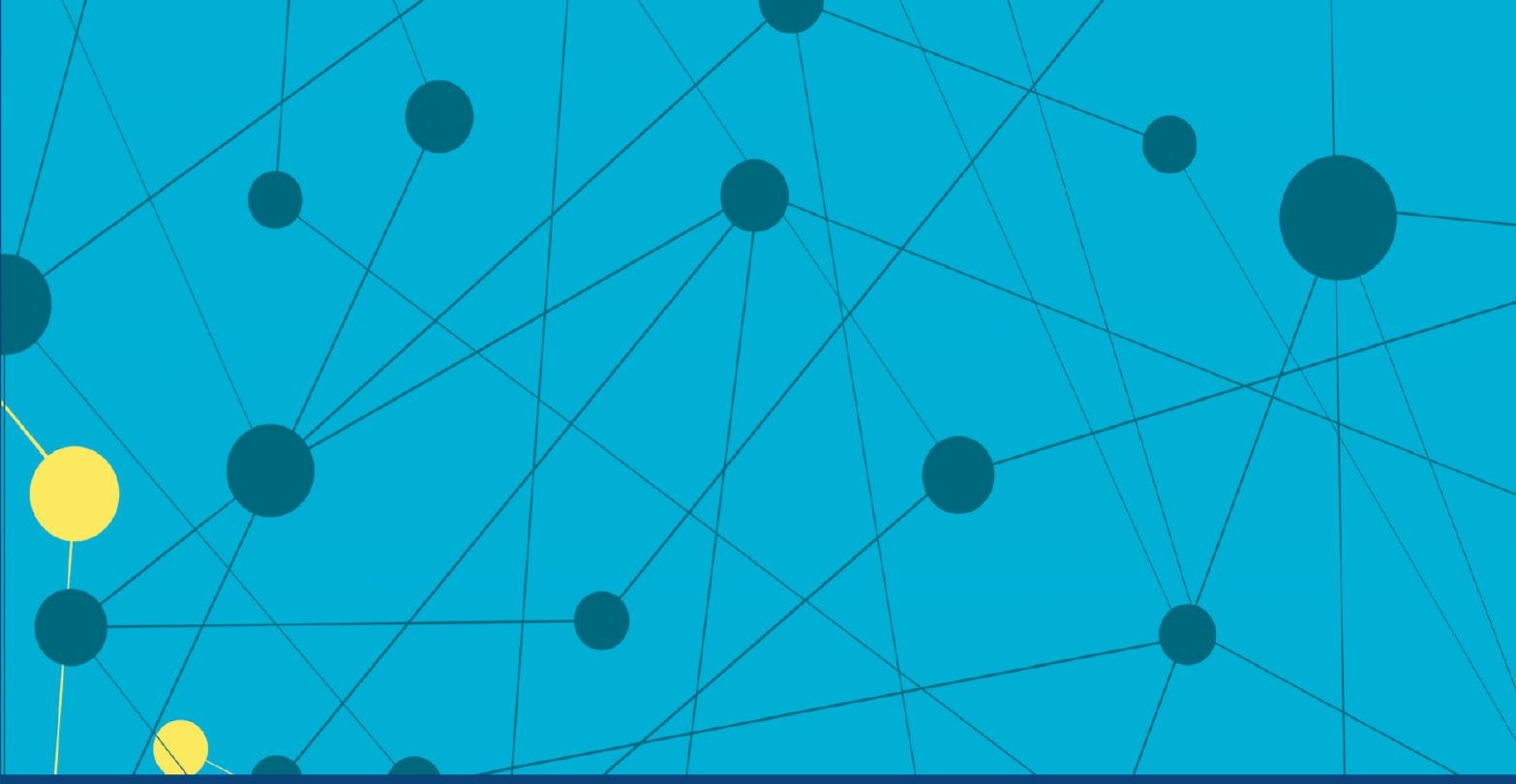

Routledge Studies in Peace and Conflict Resolution

\title{
INTERACTIVE PEACEMAKING
}

A PEOPLE-CENTERED APPROACH

Susan H. Allen

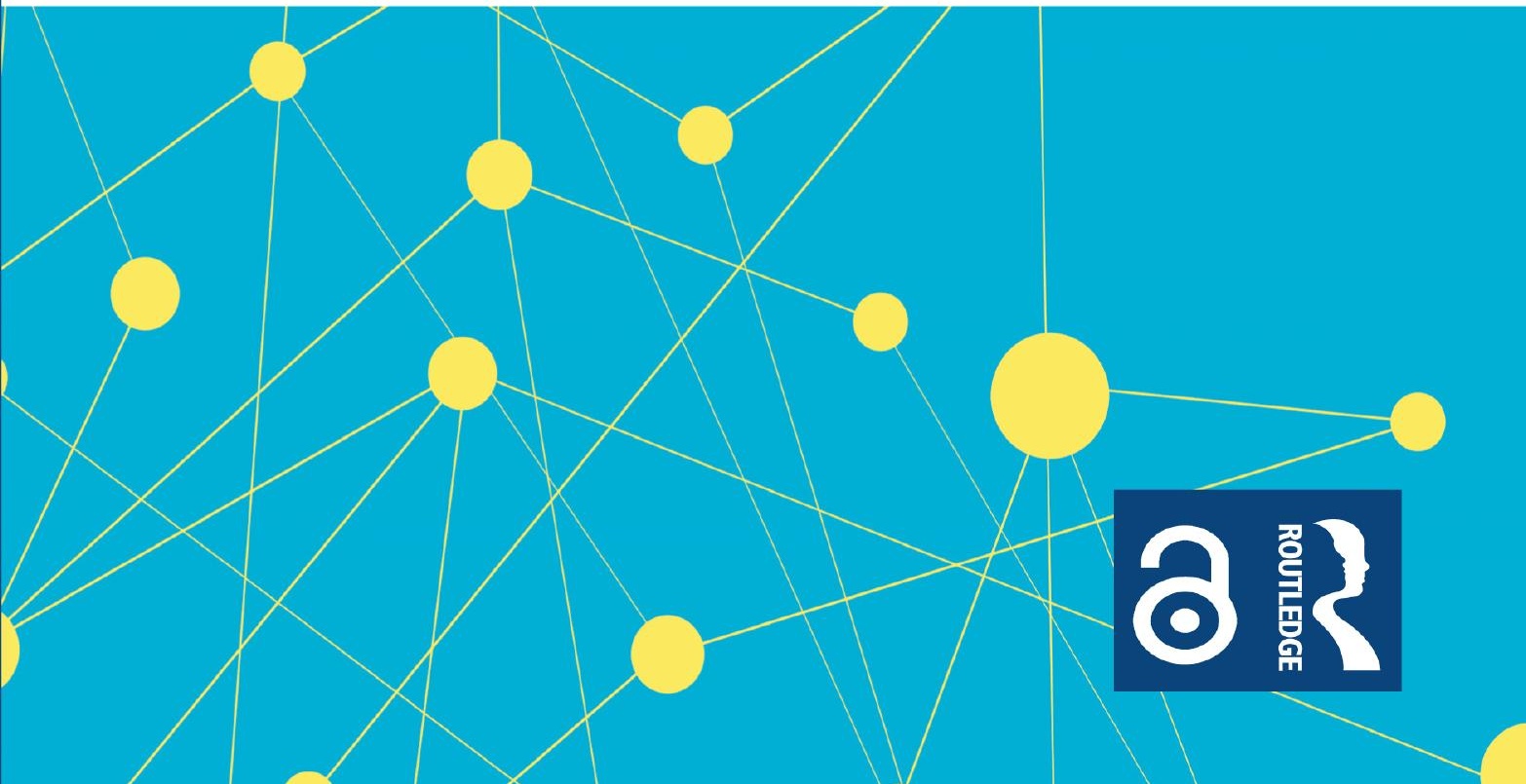


'Peacebuilders are frequently urged to engage local actors in their efforts, but advice on how to do so in a politically and culturally sensitive way is in short supply. Susan Allen has helped us fill this gap. Her powerful study of the hostile inter-ethnic fight between Georgians and South Ossetians provides concrete examples of how individuals have worked for peace in their communities, while her broader framework illuminates important lessons for all third parties on how to support individual peacemakers. Interactive Peacemaking: A PeopleCentered Approach provides a clear roadmap for both policymakers and practitioners and will be a valuable resource for all those working for peace in contested societies.'

Pamela Aall, Senior Advisor for Conflict Prevention and Management, US Institute of Peace

'Interactive Peacemaking reaffirms the rightful place reflective practice and practitioners have always occupied in peace and conflict research since its founding. It cogently demonstrates the essential roles of deep self-reflection, perseverance, and teamwork in research innovation.'

Tatsushi Arai, Associate Professor of Peace and Conflict Studies, Kent State University, USA

'Bravo to Susan Allen for providing an extraordinary insight into the inner workings of a Track 2 process from the point of view of participants, and demonstrating how practice creates theory! These are significant and unique contributions to our understanding of peacemaking.'

Eileen Babbitt, Professor of Practice, Fletcher School, Tufts University, USA

'Read this book and you will encounter a world of possibilities. Peace is made by many and it invites creativity and persistence. Indeed, as Susan Allen convincingly writes, both individuals and groups make peace. Yet in the end it is also peace that "makes" them who they are.'

Andrea Bartoli, President, Sant'Egidio Foundation for Peace and Dialogue

'Based on three decades as a scholar-practitioner with in-depth experience of the South Caucasus Susan Allen's Interactive Peacemaking: A People-Centered Approach unravels the nuance of peacemaking in a lucid and personal way. This rich and insightful book never loses sight of the people who make peace possible.'

Jonathan Cohen, Executive Director, Conciliation Resources

'Susan Allen has fashioned a significant scholarly and practical work on peoplecentered peacemaking in an under-studied area of the world. Without losing sight of global forces, she centers the work of everyday people as they make peace after war in their local communities.'

Cheryl Duckworth, Nova Southeastern University, USA 
'Interactive Peacemaking provides a unique exposition of innovative thinking in unofficial conflict resolution that is the culmination of years of reflective, professional work. It should sit on the shelf of every conflict resolution scholar and lay open on the desk of every practitioner.'

Ronald J. Fisher, Professor Emeritus of International Peace and Conflict Resolution, American University, USA

'Theories of peacemaking come alive in vibrant stories of people bridging across bloody divides. It's a thorough textbook and gripping reader, probing a longterm peace process Allen facilitated and illuminating multiple others she collaborated on in the US and other countries.'

Paula Garb, Center for Citizen Peacebuilding, University of California, Irvine, USA

'Interactive Peacemaking is packed with the sort of insights that come from long and deep engagement in conflict-affected contexts. Scholar-practitioner Susan Allen brings together the latest thinking from academia with profound observations from her long-standing peace work in multiple contexts. This is an optimistic book and is highly recommended.'

Roger Mac Ginty, Durham University, $U K$

'Stories and insights pour out of every page. The core narrative, that the voices of people in conflict must be central to crafting their peace, changes everything. It is trademark Susan Allen, heartfully weaving theory and practice to show us how.'

Susan Collin Marks, Peace Ambassador, Search for Common Ground

'In this groundbreaking book, Susan Allen builds on 13 years of engagement with local peacemakers in the Georgian-Ossetian conflict to develop a theory of interactive peacemaking. Remarkably, she draws our attention away from big headlines to the noteworthy efforts of women and men that bridge across conflict divides.'

Cécile Mouly, Research Professor, FLACSO Ecuador

'Susan Allen shines a much-needed light on how people-centered peacemaking processes work outside of the limelight, confront challenges and persist with creativity and courage. Interactive Peacemaking: A People-Centered Approach is an important contribution to the field of peace and conflict resolution written by an expert scholar-practitioner.'

Reina Neufeldt, Chair, Peace and Conflict Studies, Conrad Grebel University College, Canada

'Allen continues the distinguished tradition of scholar-practitioner peacemakers, including the late great Hal Saunders, who long convened the U.S.-Russian/Soviet Dartmouth Conference. Regional specialists will find fascinating insights into the Georgian conflicts. Peacemaking students will find valuable practical lessons.'

Matthew Rojansky, Director, Wilson Center's Kennan Institute and US Executive Secretary, Dartmouth Conference 


\section{Interactive Peacemaking}

This book examines the theory and practice of interactive peacemaking, centering the role of people in making peace.

This book presents the theory and practice of peacemaking as found in contemporary processes globally. By putting people at the center of the analysis, it outlines the possibilities of peacemaking by and for the people whose lives are touched by ongoing conflicts. While considering examples from around the world, this book specifically focuses on peacemaking in the Georgian-South Ossetian context. It tells the stories of individuals on both sides of the conflict, and explores why people choose to make peace, and how they work within their societies to encourage this. This book emphasizes theory built from practice and offers methodological guidance on learning from practice in the conflict resolution field.

This book will be of much interest to students and practitioners of peacemaking, conflict resolution, South Caucasus politics, and International Relations.

Susan H. Allen is an Associate Professor and Director of the Center for Peacemaking Practice at the Jimmy and Rosalynn Carter School for Peace and Conflict Resolution, George Mason University, USA. 


\section{Routledge Studies in Peace and Conflict Resolution}

Series Editors: Tom Woodhouse and Oliver Ramsbotham

University of Bradford

The field of peace and conflict research has grown enormously as an academic pursuit in recent years, gaining credibility and relevance amongst policy makers and in the international humanitarian and NGO sector. The Routledge Studies in Peace and Conflict Resolution series aims to provide an outlet for some of the most significant new work emerging from this academic community, and to establish itself as a leading platform for innovative work at the point where peace and conflict research impacts on International Relations theory and processes.

The Colombian Peace Agreement

A Multidisciplinary Assessment

Edited by Jorge Luis Fabra-Zamora, Andrés Molina-Ochoa, and Nancy Doubleday

\section{Theorising Civil Society Peacebuilding}

The Practical Wisdom of Local Peace Practitioners in Northern Ireland, 1965-2015

Emily E. Stanton

\section{Neighborhood Resilience and Urban Conflict}

The Four Loops Model

Karina V. Korostelina

\section{Reconciling Divided States}

Peace Processes in Ireland and Korea

Edited by Dong Jin Kim and David Mitchell

For more information about this series, please visit: https://www.routledge.com/ Routledge-Studies-in-Peace-and-Conflict-Resolution/book-series/RSPCR 


\title{
Interactive Peacemaking A People-Centered Approach
}

\author{
Susan H. Allen
}


First published 2022

by Routledge

4 Park Square, Milton Park, Abingdon, Oxon OX14 4RN

and by Routledge

605 Third Avenue, New York, NY 10158

Routledge is an imprint of the Taylor \& Francis Group, an informa business

(C) 2022 Susan H. Allen

The right of Susan H. Allen to be identified as author of this work has been asserted in accordance with sections 77 and 78 of the Copyright, Designs and Patents Act 1988.

The Open Access version of this book, available at www.taylorfrancis.com, has been made available under a Creative Commons Attribution-Non Commercial-No Derivatives 4.0 license.

Trademark notice: Product or corporate names may be trademarks or registered trademarks, and are used only for identification and explanation without intent to infringe.

British Library Cataloguing-in-Publication Data

A catalogue record for this book is available from the British Library

Library of Congress Cataloguing-in-Publication Data

A catalog record has been requested for this book

ISBN: 978-1-032-03790-5 (hbk)

ISBN: 978-1-032-03792-9 (pbk)

ISBN: 978-1-003-18900-8 (ebk)

DOI: $10.4324 / 9781003189008$

Typeset in Times New Roman by MPS Limited, Dehradun 
In memory of Dina G. Alborova (1972-2021). May her peacemaking inspire peacemakers of the future. 


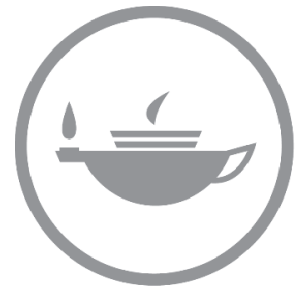

Taylor \& Francis
Taylor \& Francis Group http://taylorandfrancis.com 


\section{Contents}

Preface $\quad$ x

Acknowledgments xiv

Foreword xvi

1 What Exists Is Possible 1

2 Georgians and South Ossetians Wage War and Peace 10

3 Practice Builds Theory 18

4 People Make Peace 37

5 Process Shapes People-Centered Peacemaking 60

6 Locals Lead with Global Awareness 81

7 Peacemakers Adapt 102

8 Both Individuals and Groups of People Make Peace 112

9 Peacemaking Is Personal 129

$\begin{array}{ll}\text { Index } & 136\end{array}$ 


\section{Preface}

This book comes out of my work with many peacemakers, and the work of many other peacemakers around the world. It reflects insights and practices that many people developed together. Some of the examples highlighted in the pages that follow draw from experiences of Georgians and South Ossetians since the August 2008 war that exacerbated their divisions. Other examples in this book draw from experiences of peacemakers in other contexts. Several Georgian and South Ossetian peacemakers are highlighted in chapter three, as examples of the people who make peace. In so many ways, this book is the product of the work of hundreds of people.

I present the analysis and conclusions in this book for consideration by colleagues, asking that readers take what is useful for their own work and leave aside the rest. I offer the peacemaking practice guidance contained here for others to consider adapting as needed for their own work. I have learned in decades of peacemaking practice that every conflict is unique. Each conflict community is made up of unique individuals, with unique talents, and unique peacemaking approaches. The theories of practice that emerge from multiple conflict resolution processes and the practices that I present in this book may not work everywhere in every context for every peacemaker. Yet, they might be helpful to colleagues facing peacemaking challenges. These are theories of practice born from real-world experience. These are practices that have proven effective in some contexts. Conflict resolution practice demands a balance of learning from other contexts and previous experience while also humbly approaching the unique aspects of a particular region in crisis.

Peacemakers also must know themselves, and draw on their own personal attributes as they bring their whole selves into peacemaking processes. Where I draw from my own experience in this book, my own positionality shapes that experience. As a socio-economically privileged woman who presents as White and works as a tenured professor at a major research university in the United States, I enjoy so many privileges that make aspects of my peacemaking possible. I can do peacemaking that does not pay, at least for short periods of time. And, this position and positionality also has allowed me to find financial support that has made long-term engagement in peacemaking possible in 
specific contexts. With flexible summers, breaks from teaching responsibilities and funding for airfares, in the pre-pandemic era I frequently traveled to meet in person with peacemakers. A motto for peacemaking that I learned from South African peacemaker Susan Collin Marks is: "Keep showing up." That is only possible when peacemakers' have a livelihood and life circumstances that allow for regular visits with those embroiled in conflict. And, as a woman working in a region of the world where patriarchy is strong, I feel I was able to continue with peacemaking work in part because I was a woman working sometimes with mostly other women. I had a sense that sometimes powerful men who did not want bridges built across communities dismissed our women's work as of no consequence. We flew under the radar, disguised as women whom some expected would not have an impact. Readers with different positionalities will have different experiences.

I used the plural "we" above to refer to the multiple peacemakers I was working with in the Georgian-South Ossetian context when our bridgebuilding continued despite pressure from particularly the South Ossetian side to stop these conversations. That work was highly collaborative. No one individual could have done it alone. We each brought our own positionality and connections that allowed us to convene and facilitate as we did.

Despite all the collaborations that are required for peacemaking, I am uncharacteristically writing the book alone as a sole author. Why? As my Georgian and South Ossetian peacemaking partners have explained to me, they can each write from their individual perspective as parties to the conflict, but only international facilitators such as myself can bring an outside perspective. And, they see it as the work of a professor to connect their stories with those of other peacemakers in other contexts, drawing out some insights that may be helpful to others far from the South Caucasus, and presenting our theories of practice to the scholarly world, too. So, my Georgian and South Ossetian partners have asked me to write about our work. They also want an English-language book, to share their story more broadly than a Georgian or Ossetian language publication would allow.

My mentor Paula Garb has long been part of the coordinating team, and would be well-placed to write an English-language book about the insights that have emerged from the Georgian-South Ossetian process. But, she is not writing in detail about this process because she is focused on writing a memoir that encompasses her extensive experience with US-Soviet, USRussian, Georgian-Abkhaz, and also Georgian-South Ossetian engagement, and has encouraged me to write with a focus on the Georgian-South Ossetian process.

Over 13 years of intensive engagement since 2008, I have rarely written about the Georgian-South Ossetian civil society-based peace process rarely, with most of my comments focused on the process, rather than the content of the discussions. I have not wanted to disrupt the process by taking time away from it for writing, nor have I wanted to betray the trust in confidentiality that we all shared within the coordination team. And, I have been careful not to 
take sides with any political analysis or substantive comments on the conflict issues, as these might lend support to one group more than another. However, on two occasions, coordination team members encouraged me to write about the process, presenting our process insights, without going beyond the most general reflections on the content. The coordinators asked me to document our process. So, I did. I partnered with a graduate student, Jacquie Greiff, to write a chapter summarizing "The Georgian-South Ossetian Point of View Process" (Nan and Greiff 2013). Working with Jacquie allowed me to balance the time constraints of simultaneously convening the ongoing process and also writing about it. Later, I integrated examples from the Georgian-South Ossetian process into a chapter, "Who Rebuilds? Local Roles in Rebuilding Shattered Societies" (Allen 2017). This chapter shared parts of the GeorgianSouth Ossetian process that were already publicly available on the process website, and presented a theory of local roles in recovery in post-war contexts that had emerged from engagement with locals taking action in the GeorgianSouth Ossetian post-war context.

I wrote those two chapters under different names. Between 2013, when I wrote as Susan Allen Nan, and 2017, when I wrote as Susan Allen, I divorced and returned my name to Susan Allen. Going through divorce, and divorce mediation, while facilitating Georgian-South Ossetian dialogues was an experience. When South Ossetians spoke about the reasons for a divorce between South Ossetia and Georgia, I felt that metaphor deeply. When several participants asked me how things were at home, I teared up sharing updates of a personal nature. While my own divorce process was not ever part of the official dialogues, I mention it here as an aside, as I mentioned it alongside my peacemaking discussions. And, I want readers to understand why Susan Allen refers to things Susan Allen Nan wrote as her own.

Aside from these two chapters (2013 and 2017), this book is my first foray into presenting the Georgian-South Ossetian process and the insights that emerged from it in any detail. The coordinating group feels now, while our work is quieter during the pandemic, is an appropriate time to share more about the process publicly. I have tried to weave together examples from other places, too, in hopes that the broader peacemaking insights will resonate beyond the Georgian-South Ossetian context. I continue to learn from peacemakers in diverse contexts, and hope that others engaged in peacemaking in other contexts will find utility in the peacemaking practices presented here.

As the conflict resolution field seeks evidence-based guidance to improve our efficacy in preventing war and making peace, this book offers evidence based on practical experience. The evidence does not come in the form of data tables. Rather, it comes in the form or stories and insights that create theories of practice. These forms of evidence may speak more convincingly to some practitioners, for whom the context-specific stories with detailed examples of what is possible in peacemaking may offer more inspiration for their own work than general trends reported without regard to context. 
Preface xiii

The late Joseph Camplisson, an extraordinary Northern Irish peacemaker who worked both in Northern Ireland and also bridging between Moldovan and Trandniestrian communities, told me outsiders can be helpful as peacemakers by asking good questions and telling good stories. I hope this book does both.

\section{Works Cited}

Allen, Susan H. 2017. "Who Rebuilds? Local Roles in Rebuilding Shattered Societies." In Rethinking Humanitarian Intervention in the 21st Century, 2017, 267-86. Edinburgh: Edinburgh University Press.

Nan, Susan Allen, and Greiff, Jacquie L. 2013. "Basic Human Needs in Practice: The Georgian-South Ossetian Point of View Process." In Conflict Resolution and Human Needs: Linking Theory and Practice, edited by Kevin Avruch and Christopher Mitchell, 202-15. New York: Routledge. 


\section{Acknowledgments}

This book is the product of decades of peacemaking practice with hundreds of people engaged in difficult peace processes. Each of these people I have encountered has taught me something along the way. I have promised some that I will keep my knowledge of their peace efforts confidential as they continue their efforts for peace. Others are public about their work, so here I can acknowledge some of those public peacemakers who have taught me directly or indirectly, and scholar-practitioner colleagues who have been generous with their time and insights, all of whom contributed in some way to my writing this book: Ivane Abramashvili, Dina Alborova, Rochelle Arms Almengor, Emmanuel Anquetil, Marz Attar, Eileen Babbitt, Andrea Bartoli, Laurence Broers, Jimmy Carter, Tom Crick, Natia Chankvetadze, Jonathan Cohen, Rachel Clogg, Isabel Covic, Esra Cuhadar, Claire Delessard, Tamra Pearson d'Estree, Ronald Fisher, Mari Fitzduff, Martha Freeman, Paula Garb, Philip Gamaghelyan, Marc Gopin, Christopher Joyce, Fleur Just, Ayse Kadayifci, Giorgi Kanashvili, Nino Kalandarishvili, Giorgi Khutsishvili, Lira Kozaeva, Milt Lauenstein, Emily Linnemeir, John Paul Lederach, Manana Mebuke, Patricia Maulden, Julie Minde, Christopher Mitchell, Joyce Neu, Craig Oliphant, Lara Olson, Ariel Otruba, Oleh Protsyk, Arthur Romano, Ekaterina (Kate) Romanova, Daniel Rothbart, Malkhaz Saldadze, Mara Schoeny, Juliet Schofield, Nina Selwan, Larissa Sotieva, Mira Sovakar, Margarita Tadevosyan, Gevorg Ter-Gabrielyan, William Ury, Stan Veitsman, Laura Villanueva, Thomas de Waal, Siegfried Woeber, and Paata Zakareishvili.

I am grateful for the collegial atmosphere in George Mason University's Carter School for Peace and Conflict Resolution that encouraged my work. I especially appreciate colleagues who commented on draft chapters of the book: Charles Chavis, Paula Garb, Marc Gopin, Susan Hirsch, Doug IrvinErikson, Karina Korostelina, Christopher Mitchell, Agnieszka Paczynska, Dan Rothbart, Richard Rubenstein, and Solon Simmons. Thanks to Terrence Lyons for inviting me to present a chapter draft for comment at the Carter School series of seminars he convened for collegial commenting on drafts and all the colleagues who showed up there to help me improve 
Chapter Three. Thanks to Paula Garb and Arthur Romano for encouraging me to keep on writing as we compared notes in our writing processes.

Thank you to all those who read the full draft or most of it and provided me helpful editorial suggestions in the final stages of completing the manuscript: Tatsushi Arai, Jonathan Cohen, Michael Evans, Paula Garb, Christopher Mitchell, and Reina Neufeldt.

This book would not have been possible without the ongoing partnership with Margarita Tadevosyan on the Georgian-South Ossetian peacemaking process. Her exceptional strength as a scholar-practitioner gave me the confidence to turn my focus from the process, focusing on the writing, while confident she would continue to nurture peace.

I also want to thank all those who supported me in the writing process. A Fulbright Scholar Award allowed me time in Tbilisi to focus on the book. George Mason University supported my participation in the Faculty Success Program at the Center for Faculty Development and Diversity, where I learned to make regular time for writing, and the university provided me a semester of study leave and also allowed me to work a reduced schedule for reduced pay to focus on the book one year. Melanie became my writing buddy, offering monthly encouragement. And, throughout the process from book proposal through final manuscript submission, the team at Routledge, including Andrew Humphreys, Bethany Lund Yates, and series editors Tom Woodhouse and Oliver Ramsbotham were exceptionally helpful. I also appreciate the anonymous peer reviewers who provided very useful suggestions and encouragement on the early draft chapters they reviewed.

Mike made me healthy food to fuel writing and believed I would complete the book on time. Oliver came through as outstanding computer support whenever I called, helping me with everything from curving the font for a diagram to recovering a full chapter that I thought had disappeared from my computer. Elaine and Sarah came for a writing retreat that jumpstarted the book. The Eastern Village Cohousing writing group gave me precious hours of focused writing. Elaine created a lakeside writing retreat that led to a full chapter. Harry, Josh, Jonah, Oliver, and Mike walked Marsh the puppy. And I also appreciate that Marsh often took me for walks.

Thank you, all! 


\section{Foreword}

This great book Interactive Peacemaking: A People-Centered Approach is now with us and there is no doubt that it will fill in a significant gap in the field of peace and conflict studies. However, to appreciate this book entirely, it is essential to get to know its author first. Dr. Susan H. Allen is an Associate Professor and Director of the Center for Peacemaking Practice at George Mason University's Jimmy and Rosalynn Carter School for Peace and Conflict Resolution, which I lead as its Dean.

Dr. Allen is an academic who has dedicated her work to peacemaking. She is a conflict resolution expert with unique field practice experience, particularly in the Georgian-South Ossetian context. The Interactive Peacemaking book that you are about to read is the outcome of Dr. Allen's scholarly and practitioner engagement in the Caucasus region since 2008. In other words, to understand what peacemaking is all about in the context of the Georgian-South Ossetian conflict, this is the book you need to read and make part of your teaching and research. Moreover, while enjoying an in-depth analysis of this particular context, you would also be following Dr. Allen's peacemaking footsteps in many other parts of the world, which adds so much more richness and comparative angle to discussions.

As Dr. Allen rightly points out, every conflict is different, so peacemaking efforts that follow need to be tailor-made. She has been doing this by working with many diverse local peacemakers in the Georgian-South Ossetian context. However, it is also true that every practitioner is likely to have a different narrative of the same peacemaking process. This is why it is important to note that we have the opportunity to read a well-established scholar's account and benefit from her first-hand peacemaking experiences with this book. The volume serves an excellent purpose in unpacking a forgotten conflict with great care and dedication. You would discover all ins and outs of peacemaking on the ground, particularly from the perspective of a third party. Subsequently, I know that this book will become a must-read item for peace studies scholars, students, and practitioners.

To explain the peacemaking practice, the book focuses on the bottom-up approach of peacemaking and how it has been undertaken between Georgians and South Ossetians. It builds its theoretical approach based on practice, 
which is highly appropriate for this book. It is all about people-centered peacemaking, and how locals shape and lead it with global awareness. The book makes an outstanding contribution to the field of everyday peacebuilding by positioning conflict-affected populations and their peacemakers in the center of all discussions. The argument will present you with many nuances about peacemaking and how an external actor, whether this is an individual or organization, can engage with different local actors.

This book is a real gem for peacemaking!

Furthermore, many helpful approaches are presented in the book to mitigate the challenges that such peacemaking environments are likely to bring about. Therefore, you will not only have an understanding of peacemaking practice in the Georgian-South Ossetian context, but also how different responses are applied, supported, and re-generated in the face of ongoing challenges. Although Dr. Allen is exceptionally modest in her approach in terms of the applicability of this peacemaking experience in other contexts, as a scholar and practitioner of peace studies with field research experience in many different conflict-affected environments across the world, I know that whether you are working in peacemaking in Africa, Asia, Europe or Americas, you would indeed, find many helpful pointers for application.

I am also particularly proud that Dr. Allen is a faculty member at the Carter School, and this book reflects our community's vision for peacemaking so well. As the Carter School, we believe in the importance of the nexus between peace and justice. To achieve that, our community believes that peacemaking has to be undertaken in an inclusive and participatory manner by all relevant stakeholders. However, local actors must take a lead role in making and building their own peace. This is the only way that we can talk about a just and sustainable peace. This is the only way that we can address the root causes of the conflict. This is the only way that a new peaceful future could have a chance. Under Dr. Allen's leadership, the Center for Peacemaking Practice at our School engages in resolving conflicts worldwide with this understanding. One of the latest initiatives of this Center, the Better Evidence Project, has already contributed to producing and presenting an excellent body of evidence on peacemaking practice. Therefore, Interactive Peacemaking brings together all that peacemaking experience in a single volume and provides to you in the most insightful and accessible way.

I am wholeheartedly welcoming this book Interactive Peacemaking: $A$ People-Centered Approach and thanking Dr. Allen for making this profound contribution to our field.

Alpaslan Özerdem

Dean

Jimmy and Rosalynn Carter School for

Peace and Conflict Resolution

George Mason University 


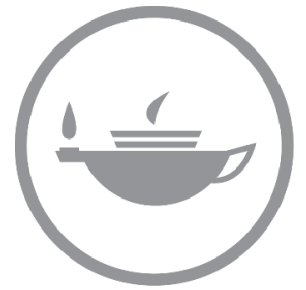

Taylor \& Francis
Taylor \& Francis Group http://taylorandfrancis.com 


\section{What Exists Is Possible}

"There is no possibility to do any peacemaking with the Georgians and South Ossetians," a senior international diplomat once told me when we were introduced at a Washington, D.C. reception. At the time, in 2014, I had been peacemaking with Georgians and South Ossetians since the August 2008 war that escalated the conflict over South Ossetia's status. The political status issues remained divisive; Georgia claimed South Ossetia as part of Georgia, while South Ossetia claimed independence. Still, Georgians and South Ossetians had sought and reached agreement on many issues short of the overall political status question. These agreements were making life better for many people. I explained to the visiting diplomat that I knew Georgians and South Ossetians who were devoting their lives to doing peacemaking between their communities, and that I had worked with them to convene peacemaking dialogues that engaged senior people on each side and contributed to significant humanitarian initiatives and confidencebuilding measures. He dismissed my direct experience and repeated, "It's just not possible." He did not appear to have any interest in learning about what was happening out of the limelight, behind the scenes, and in confidential conversations. I imagine the diplomat I spoke with may have been referring to official peacemaking that would lead to officially signed agreements and envisioning men in ties who meet in Geneva. I was describing a people-centered approach to interactive peacemaking.

This book is for those who want to learn about people-centered peacemaking from the perspective of those who do peacemaking. Johan Galtung (Galtung 1976) distinguishes peacekeeping, peacemaking, and peacebuilding approaches, and emphasizes "peacemaking" as the approach to resolve violent conflict, in contrast to peacekeeping's focus on separating the parties and peacebuilding's long-term focus on the development of structures and infrastructures for peace. In "An Agenda for Peace" (Gali 1992, 5) Boutros Boutros Gali, writing as Secretary-General of the United Nations, defines peacemaking as "action to bring hostile parties to agreement, essentially through such peaceful means as those foreseen in Chapter VI of the Charter of the United Nations." Chapter VI of the UN Charter foresees, "negotiation, enquiry, mediation, conciliation, arbitration, judicial settlement, resort 


\section{What Exists Is Possible}

to regional agencies or arrangements, or other peaceful means of their own choice" ("Chapter VI: Pacific Settlement of Disputes" 1945). Boutros Boutros Gali highlights that peacemaking aims to resolve "the issues that have led to conflict" (Gali 1992, 4).

Men's and women's peacemaking has sometimes quietly and without fanfare shaped recent years of conflicts. This peacemaking is possible. What exists is possible.

Practitioners have long known that people-centered approaches are effective. International Alert included the people-centered approach as the first of ten principles in its Code of Conduct: "Primacy of People in Transforming Conflicts" ("Code of Conduct: Conflict Transformation Work" 1998). International Alert explained,

effective conflict transformation is only possible with the consent and participation of those most affected by the conflict and we are committed to strengthening the capacities of local actors and organisations to contribute to peacemaking and peace-building within their societies. ("Code of Conduct: Conflict Transformation Work" 1998, 5)

Of course, the practitioner perspectives offered in the following pages tell - and can only tell - part of the story. We peacemakers want our efforts to be successful, and we may underscore and assess progress in small changes. We tend not to focus on geopolitical, economic, social, psychological, or cultural shifts except as they directly impact peacemaking. Likewise, this book focuses specifically on peacemaking rather than conflict analysis, official diplomacy, or military relations. ${ }^{1}$ Emphasizing the role of people in peacemaking, this book builds on the movement of people-centered approaches to development, security, and education (Korten 1984; Andersen 2012; Toh and FlorescaCawagas 1997).

There has already been substantial work in building from practice to theory of interactive conflict resolution. Ronald Fisher has led the way with much of this work. Fisher (Fisher 1997) focused the conflict resolution field on interactive conflict resolution, considering the practices of unofficial discussions between people from groups involved in violent conflict. He defined interactive conflict resolution as,

facilitated face-to-face activities in communication, training, education, or consultation that promote collaborative conflict analysis and problem solving among parties engaged in protracted conflict in a manner that addresses basic human needs and promotes the building of peace, justice, and equality. (Fisher, 1997, p. 8)

Fisher highlighted multiple approaches to interactive conflict resolution, including the work of John Burton and Problem Solving Workshops; Vamik Volkan and the psychodynamic approach; Herbert Kelman and action 
research; Christopher Mitchell's Analytical Problem Solving Workshops; Harold Saunders' Sustained Dialogue; and Ronald Fisher's own Third Party Consultation model of interactive conflict resolution. Fisher (Fisher 2005) collected case studies of interactive conflict resolution as a form of peacemaking, documenting the contributions interactive conflict resolution made to multiple peace processes in contexts of ongoing protracted violent conflict.

The insights presented here add to our understanding of interactive conflict resolution by emphasizing the people-centered aspects of the interactive conflict resolution approach. People-centered interactive peacemaking can be seen as part of the development of what Richmond refers to as the fourth generation of peace work, hybrid peace. The hybrid peace approach acknowledges both local contextual forces and global international forces in shaping peace. Richmond describes a post-liberal peace, "one where international norms and institutions interact with different, contextual, and localized polities" (Richmond 2014, 108). The people-centered approach resonates with the fourth generation approach that highlights "the notion that societies build peace and states, not only donors and state elites" (Richmond 2014, 119).

This book draws on my own experience in the South Caucasus and beyond and on peacemaking experiences of others in different contexts, to create a richer understanding of the possibilities and challenges of making peace today. It keeps the focus on people who engage in interactive conflict resolution and how peacemaking impacts people's lives. It returns throughout to the specific context of the Georgian-South Ossetian peacemaking experience, to allow for a more detailed and in-depth reflection.

\section{Sharing a Peacemaking Story}

This book tells the story of our work over 12 years, since Fall 2008, and presents what we have learned and gathered from our experience. Where relevant, insights from other processes are introduced, to provide a glimpse of how peacemaking unfolds in other contexts. While I am the author of this book, its insights and story have developed through years of reflective conversations, evaluation, action research, and engaged scholarship with Georgian and South Ossetian partners. After years of my steadfastly protecting the confidentiality of our peacemaking practice, these partners have urged me to share our insights and tell our story, so that other peacemakers may learn from our experience. To complete this book I have consulted my partners in numerous internet-based team meetings, engaging them in ongoing reflection on our practice, which primarily helps to strengthen that peacemaking practice but also helps us more fully reflect on it.

Six of the individuals involved from the conflict region are introduced in chapter four, "People Make Peace." Each of the peacemakers profiled here has agreed to share their stories publicly, allowing me to reflect on their peacemaking in this book. Each of these peacemakers is an independent 
thinker who works to shape their own society's approach to the conflict. Some have led NGOs, others have taught at a university. Some have moved in and out of government. Funding for this work has sometimes come through projects, some of which supported "project coordinators" who received stipends to support their time as they nurtured and shaped the peacemaking process. The role of coordinator changed over time, depending on who was not in government, who had time to devote to the project, and the project's specific focus as it moved through different stages.

International facilitators have also shifted over time, as different individuals had paid positions working on the process and others volunteered time when they were available. Dr. Lara Olson (teaching at the University of Calgary) served as a facilitator in an early stage of the project and then later as an evaluator for two years of the project. Dr. Ekaterina Romanova (now at the World Bank) was a facilitator in the early years, but then the time demands of her other professional work prevented her regular engagement. Dr. Philip Gamaghelyan (now at University of San Diego) was influential in mid-years of the process, bringing helpful innovations as the process expanded. Dr. Margarita Tadevosyan (now at George Mason University) has worked on the project for the last six years, sometimes paid and sometimes as a volunteer, and has led discrete, funded portions of projects in recent years. My mentor Dr. Paula Garb has worked in the South Caucasus for many decades and has been deeply involved in the peacemaking process during some years, when her other activities have allowed, and led an initiative to connect Georgian and South Ossetian students through online classes as part of the larger peacemaking process.

Having learned from all of these people while working together, I write in this book about my experience. I was first introduced to the South Caucasus when a graduate student at George Mason University's Institute for Conflict Analysis and Resolution in 1993. The Institute hosted visiting scholars from Yerevan and Baku and a graduate student from Tbilisi. Two years later, we hosted a visiting scholar from Tbilisi, who brought a letter asking the Institute to consider addressing the Georgian-Abkhaz conflict. I traveled in 1996 with the then Director of the Institute, Dr. Kevin Clements, to Tbilisi and Sukhum(i). Early in 1997, we brought Georgians and Abkhaz together in the U.S. for an exploratory dialogue. I learned from the challenges we faced, and plunged into conflict resolution processes for Abkhazia and Transdniestria, and studied those focused on South Ossetia. This work introduced me to many talented peacemakers in these parts of the world, and I share here insights drawn from my experience with them, and from the experiences of other peacemakers throughout the world.

\section{Organization of the Book}

This first chapter introduces the book. It overviews the book's core themes and situates these within current conversations about conflict resolution in 
general, interactive conflict resolution specifically, and broader conversations in sociology, anthropology, political science, international relations, and social science methodology.

The next chapter introduces Georgian-South Ossetian conflict context and the peacemaking efforts focused on that context. The chapter reviews the official and unofficial peace process since the 1990s, as well as the intensive unofficial peacemaking process that I have convened with Georgian and South Ossetian partners over the last 12 years.

The third chapter presents the methodological basis for the book, explaining how scholar-practitioners of conflict resolution move from practice to theory. The chapter begins with an explanation of the theory-practice gap in the conflict resolution field and efforts to bridge that gap, and then explores how to identify theories in practice. It details four ways of learning through practice: engaged scholarship, reflective practice, evaluation, and action research, and offers examples of such work with Georgian and South Ossetian peacemakers.

The fourth chapter argues that, while institutions and governance structures surely influence war and peace, individuals are essential drivers of peacemaking. People make peace. Many individual people make choices that add up to war or peace. While not discounting the role of the most senior political or military leaders as people who shape violence and peace, this chapter devotes significant attention to less high-profile people who have made Georgian-South Ossetian peacemaking a personal focus, and who have shaped the relationship through their peacemaking efforts in unofficial dialogues and quiet conversations with their leadership. The chapter profiles six such individuals - their varied backgrounds and their shared commitment to humanitarian goals. This chapter also includes a brief auto-ethnographic reflection on the author's engagement in the peacemaking process. The chapter weaves sections of analysis with narratives that describe key moments when individual peacemakers made decisions that shaped the peacemaking process.

The fifth chapter describes the "process choices" that peacemakers make, acknowledging individual, group, and society-level considerations that shape these choices. Specific examples of process choices made by Georgian and South Ossetian peacemakers allow for more in-depth explanations of the rationales behind these choices. One set of choices focuses on pushing the envelope: safely and carefully expanding the leeway offered for crossconflict contact by a repressive regime. Peacemakers gradually stretched the limits of what the regime allowed, all the while working transparently. Other choices focus on setting agendas and inviting participants for dialogue discussions: convening people with expertise on selected issues and allowing space for all participants to shape the discussion, share analysis, plan next steps, and influence their home communities. There are still other choices focused on complementing the official negotiation processes through unofficial peacemaking dialogue - navigating the ways these processes need to 
stay separate, and bringing together the strengths of each process Peacemakers also choose how to engage with the dominant narratives or propaganda that shape societal attitudes toward the peace process. Scattered throughout the chapter are several examples of decision points in peacemaking process development.

The sixth chapter focuses on a core aspect of the process: local leadership in global context. In the peacemaking efforts of Georgia and South Ossetia, the individual strengths each person brought to the team allowed for partnerships that expanded the team's possibilities. The Georgian and South Ossetian peacemakers have kinds of legitimacy in their local communities that is only possible when someone lives long-term in that community. Their colleagues and compatriots know that these peacemakers themselves will have to live with the results of their efforts. In addition to this legitimacy, Georgian and South Ossetian peacemakers brought crucial local expertise and local relationships to the process. This chapter shows how locals lead within the peacemaking process, and compares and contrasts the strengths and constraints of locals and internationals involved in the process, examining multiple locally-led initiatives. These initiatives are nested within regional and global dynamics that shape them.

Chapter 6 includes several stories of local leadership and situates them in context. In the Georgian-South Ossetian story, contextual factors that shaped the peacemaking process are varied and include the Russian relationship with the West, a change in government in Georgia, the Sochi Olympics, the coronavirus pandemic, and renewed fighting over the disputed region of Nagorno Karabakh. This chapter considers how these factors affected choices local leaders made in the peacemaking process, and how global shifts and local political developments affected the peacemaking process. Its themes include perseverance and working within the realm of the possible. The chapter presents the phases of the peacemaking process as it has shifted in response to contextual changes, including changes in the funding available for the peacemaking work, and also major changes in peacemaking during the coronavirus pandemic. In addition, the Fall 2020 outbreak of active war between Armenia and Azerbaijan over the disputed region of Nagorno Karabakh shaped the Georgian-South Ossetian discussions. The adaptations to work online created both advantages and disadvantages over the era of in-people peacemaking. Chapter six concludes with insights on building constructive partnerships between locals and with internationals to design and implement a robust, multifaceted peacemaking process that can grow and adapt over time.

Chapter 7 highlights ways peacemakers adapt. It discusses possibilities and constraints of people-centered peacemaking in contexts where civil society engagement in peacemaking is limited. Drawing on examples from multiple restrictive environments where there are limits on peoples' freedom to do peacemaking as unofficial representatives of their communities, the chapter offers suggestions for ways to expand the space available for 
interactive conflict resolution. Here, we return to the beginnings of interactive conflict resolution with the engagement of academics in analytical workshops. Academic engagement continues as a potential mode for constructive contact between adversarial groups.

Chapter 8 looks at the ways groups of individuals work together for peacemaking. Chapter 8 acknowledges peacemaking requires both individual agency and also teamwork. The chapter asks what is gained by bringing the people-centered peacemaking approach to the field, and highlights the long-term group efforts involved in interactive peacemaking. This long-term teamwork approach points to the possibilities of networks enhancing interactive conflict resolution practice. This discussion suggests guidance on developing and coordinating within peacemaking networks.

Chapter 9 presents an analysis of the characteristics of successful peacemaking processes. It also offers practitioners a synthesis of practical guidance that emerges from considering peacemaking experience. Finally, the chapter concludes with the core arguments of the book, offering scholars a synthesis of the theoretical insights and reflecting on their significance for peacemaking.

The pages that follow focus on peacemakers, the process choices they make, and how they persevere through changing circumstances. This centering of people, process, and perseverance contrasts with approaches that focus on governments, power, institutions, and structures, or on aspects of the individual and social experience, such as narrative, identity, culture, group dynamics, systems change, and so on. Of course, conflicts and their resolution are complex processes, and all of the approaches listed here (and more) are relevant to understanding aspects of peacemaking, but this book foregrounds individuals engaged in long-term peacemaking, since much other literature has not.

As I was finalizing this book manuscript, I spoke with my colleague Karina Korostelina about the movement from practice to theory (Korostelina 2021). I was struck especially by Karina's comment that building theory from practice requires that we bridge many types of theories - structural, narrative, cultural, and more. I've focused this book on people, and a people-centered approach to peacemaking, because the people involved in peacemaking are influenced by structures, narrative, culture, power, racism, psychodynamics, political institutions, sociological trends, and more. When we focus on individual people engaged in peacemaking we can see the multidimensionality of conflict resolution. The people-centered approach is inherently a transdisciplinary one, rooted as it is in practice.

McKenzie Wark (Wark 2020, 2) presents scholarship as "the common task of knowing the world." But, as Wark describes, each scholarly approach sees different aspects of the world. No one approach sees the world in its totality. The purpose of collaborative work, Wark suggests, is

not so much to produce a seamless picture of the whole, but to understand the differences between all the partial sensings. The common 
task is to produce a knowledge of the world made up of the differences between ways of knowing it. (Wark 2020, 4)

Over a decade of experience has produced insights that enrich the literature and strengthen our understanding of peacemaking practice. These insights complement those that emerge from other approaches.

\section{Note}

1 Those seeking a fuller understanding of peace and conflict dynamics and the history of disciplinary approaches to peacemaking will want to engage broadly with approaches informed by political science (Paris 2004; Zartman 2015), sociology (Coser 1964), psychology (Lewin 1997; Sears, Huddy, and Levy 2013; Bretherton and Law 2015), anthropology (Black and Avruch 1993), economics (Boulding 1945), and many other perspectives on peacemaking (Ingrid SandoleStaroste et al. 2008).

\section{Works Cited}

Andersen, Louise R. 2012. "Something's Gotta Give: Security Sector Reform and United Nations Peace Operations." African Security 5 (3/4): 217-35.

Black, Peter W., and Kevin Avruch. 1993. "Anthropologists in Conflictland: The Role of Cultural Anthropology in an Institute for Conflict Analysis and Resolution." Political and Legal Anthropology Review 16 (3): 29-38.

Boulding, Kenneth Ewart. 1945. The Economics of Peace. Prentice-Hall, Inc.

Bretherton, Diane, and Siew Fang Law. 2015. Methodologies in Peace Psychology Peace Research by Peaceful Means. 1st ed. 2015. Peace Psychology Book Series, 26. Cham: Springer International Publishing. 10.1007/978-3-319-18395-4.

"Chapter VI: Pacific Settlement of Disputes." 1945. United Nations. https:// www.un.org/en/sections/un-charter/chapter-vi/index.html.

"Code of Conduct: Conflict Transformation Work." 1998. International Alert. https:// www.international-alert.org/sites/default/files/library/Code $\% 20 \mathrm{of} \% 20$ Conduct.pdf.

Coser, Lewis A. 1964. The Functions of Social Conflict. 1st Free Press pbk. ed. Free Press Paperback 90681. New York: Free Press of Glencoe.

Fisher, Ronald. 2005. Paving the Way: Contributions of Interactive Conflict Resolution to Peacemaking. Lexington Books. https://rowman.com/ISBN/978073 9112274/Paving-the-Way-Contributions-of-Interactive-Conflict-Resolution-toPeacemaking.

Fisher, Ronald J. 1997. Interactive Conflict Resolution. 1st ed. Syracuse Studies on Peace and Conflict Resolution. Syracuse, N.Y: Syracuse University Press.

Gali, Boutros Boutros. 1992. "An Agenda for Peace: Preventive Diplomacy, Peacemaking, and Peace-Keeping." United Nations. https://www.un.org/ ruleoflaw/files/A_47_277.pdf.

Galtung, Johan. 1976. "Three Approaches to Peace: Peacekeeping, Peacemaking, and Peacebuilding." Impact of Science on Society 1 (2): 282-304.

Garb, Paula. 2009. "The View from Abkhazia of South Ossetia Ablaze." Central Asian Survey 28 (2): 235-46. 10.1080/02634930903034856. 
"Independent International Fact Finding Mission on the Conflict in Georgia: Report." 2009. European Union. https://www.echr.coe.int/Documents/HUDOC_38263_08_ Annexes_ENG.pdf.

Korostelina, Karina. 2021.

Korten, David C. 1984. "Strategic Organization for People-Centered Development." Public Administration Review 44 (4): 341-52. 10.2307/976080.

Lewin, Kurt. 1997. Resolving Social Conflicts; and, Field Theory in Social Science. Washington, DC: American Psychological Association.

Paris, Roland. 2004. At War's End: Building Peace after Civil Conflict. Cambridge, U.K.: Cambridge University Press.

Richmond, Oliver P. 2014. Peace: A Very Short Introduction. 1st ed. Very Short Introductions 407.Oxford: University Press.

Sandole-Staroste, Ingrid, Dennis JD Sandole, Sean Byrne, and Jessica Senehi. 2008. Handbook of Conflict Analysis and Resolution. Taylor and Francis. 10.4324/97802 03893166.

Sears, David O, Leonie Huddy, and Jack S Levy. 2013. The Oxford Handbook of Political Psychology. 2nd ed. New York: Oxford University Press.

"Timeline of Georgian-Ossetian Conflict (1989-2008)." 2020. "Timeline". Institute for the Study of Nationalism and Conflict. https://www.sutori.com/story/k-art-ulosuri-konp-lik-tis-droit-i-crp-ivi-1977-2008--746R3FMiftYruKBSnkEUAodd.

Toh, Swee-Hin, and Virginia Floresca-Cawagas. 1997. "Towards a People-Centred Education: Possibilities and Struggles in the Philippines." International Review of Education/Internationale Zeitschrift Für Erziehungswissenschaft/Revue Internationale de l'Education 43 (5/6): 527-45.

Wark, McKenzie. 2020. Sensoria: Thinkers for the Twenty-First Century. London, England: Verso.

Zartman, I William. 2015. Preventing Deadly Conflict. War and Conflict in the Modern World. Cambridge, UK: Polity Press. 


\section{Georgians and South Ossetians Wage War and Peace}

The chapters that follow repeatedly return to the stories of peacemakers working in the Georgian-South Ossetian context. This chapter provides a brief orientation to that context and the peace process there. While the focus of the book is on peacemakers and peacemaking, this chapter provides a glimpse of the context in which some of that work takes place.

As illustrated in Figure 2.1, Map of the South Caucasus Region, the communities of Georgia and South Ossetia are located in the South Caucasus region, south of Russia and north of Armenia and Azerbaijan. The Black Sea lies to the west, and the Caspian Sea to the southeast, just out of view of this map.

As visible in the map, the North Caucasus mountain range in the northern part of both communities. The North Caucasus is a formidable range. The highest peak, Mount Elbrus, reaches 18,510 feet above sea level. The range is impassible in many areas, except to mountain goats and the most agile people. The Georgian and South Ossetian communities enjoy mountains that are snow-capped year-round, and valleys that produce delicious fruits and vegetables.

The map shows the cities Tbilisi and Tskhinval(i). Tbilisi is the capital of Georgia. Tskhinval(i) is the capital of South Ossetia, called Tskhinval by the Ossetians and Tskhinvali by the Georgians. I use the name with the " $\mathrm{i}$ " in parentheses to indicate the two different ways the city is named. Tskhinval(i) is located adjacent to the ceasefire line. People living in Tskhinval(i), the largest population center in South Ossetia, point towards their close proximity to the Georgian military as part of the reason they appreciate the Russian military presence on their side of the ceasefire line.

The different city name in Georgian and Ossetian noted above reflects the different languages; Georgian and Ossetian are entirely different languages. They are not dialects of one language. They do not even share the same language family. Georgian is one of the unique Caucasus languages in the Iberian family that linguists do not relate reliably to any other language family. Ossetian is an Indo-European language of the Iranian language group. And, both are entirely distinct from the Slavic family of languages, including the Russian language. Most older Georgians and South Ossetians learned 


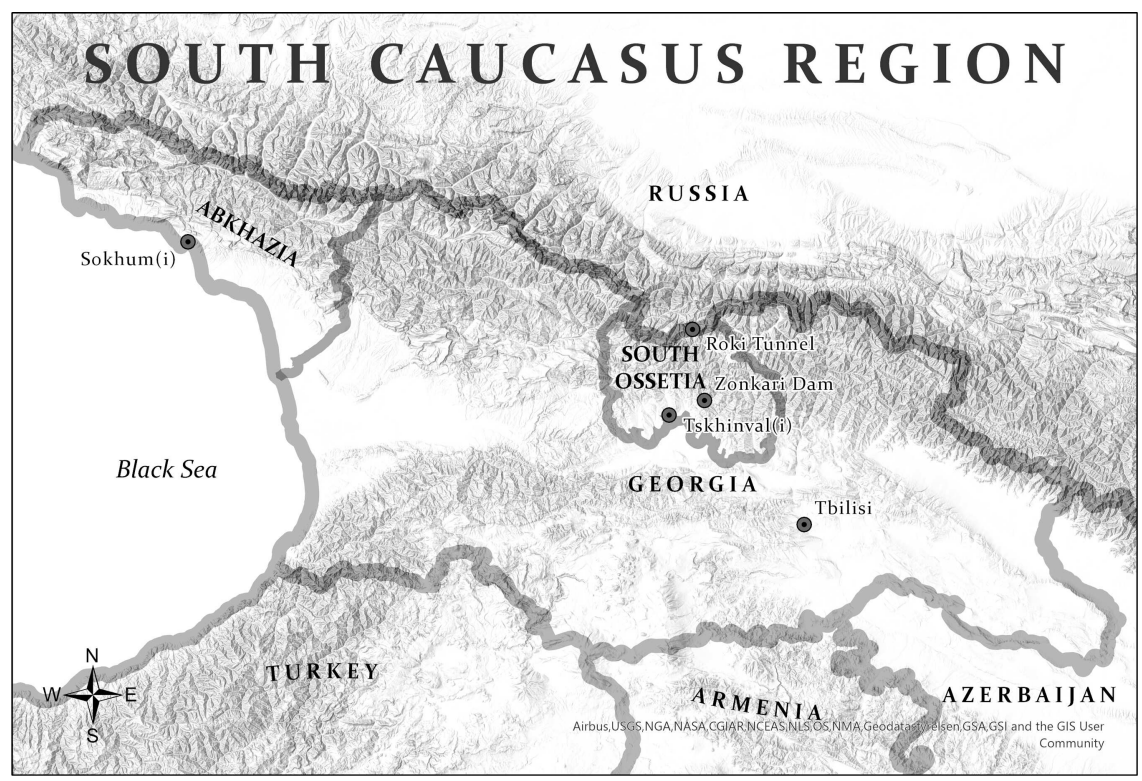

Figure 2.1 Map of the South Caucasus Region. Map by Ariel Otruba.

some Russian in school, as Russian was the common language that connected the diverse parts of the Soviet Union. Now, Georgian school children may learn English or Western European languages, and South Ossetian children often study in Russian. Russian is still often the common language used for communication between Georgians and South Ossetians in peacemaking discussions. When Georgians and South Ossetians communicate with each other in Russian, they are both speaking a language that is likely not the language they speak at home.

Returning to the map, we see two other man-made features: the Roki Tunnel, and the Zonkari Dam. South Ossetia has only one area where regular vehicle traffic can cross the North Caucasus mountains by road: the Roki Tunnel, marked on the map. South Ossetians drive north about five hours to reach Vladikavkaz in North Ossetia in Russia. Going through the Roki Tunnel is the one road out of South Ossetia directly into Russia. Other roads out of South Ossetia all go through undisputed Georgian territory. The map also shows the location of the Zonkari Dam, which is discussed as part of the peacemaking process described in Chapter Seven. The Zonkari Dam holds back a reservoir of water high in the mountains, creating a mountain lake. Thanks to many years of peacemaking efforts, water that flows from the dam irrigates farms on both Georgian and South Ossetian sides of the ceasefire line.

The peoples of the South Caucasus emphasize education, the arts, and hospitality, facilitated with fresh, flavorful dishes of meat, wine, cheese, nuts, 
and flavorful local produce. Georgians have told me that when God was handing out land to each of the peoples, they were busy hosting guests at a feast, and so the Georgians came late. God had nothing left but his own very best land to share with them, so he gave Georgians the best land of all. South Ossetians have told me of the Narts, great beings of the mountains who engage in adventures that somewhat resemble Greek myths. The Narts shared nature-based traditions that the Alans - the Ossetian people - have passed down through the generations, traditionally living in harmony with the environment with which they have been blessed. South Ossetians have shared with me their love for the clean mineral water and natural resources that are abundant in their pristine mountainous region.

While for years these communities shared the highest inter-ethnic marriage rate in the Soviet Union, they have been in conflict since 1989, when disagreements about the status of South Ossetia began to escalate. These people share much in common, but they are also mired in a deep divide: the Georgian-South Ossetian conflict.

In the case of Georgia and South Ossetia, the "issues that have led to conflict," as Boutros Boutros Gali refers to the focus of peacemaking efforts globally, have developed over decades and even centuries of inter-ethnic and political relationships, and also include issues that have emerged since 1989 and into 2008. An ongoing issue, however, is how Georgian and South Ossetian societies see each other. In many years of discussions about the conflict in many Georgian homes, Georgians have proudly told me how well Georgia has treated the South Ossetian guests who came from the mountains to live in Georgia. Georgians are generally proud of their culture of hospitality, and some Georgians see South Ossetians as welcome "guests" in Georgia. Meanwhile, South Ossetians have shared that it is insulting to be called guests in their own home. South Ossetians explain that they have lived in South Ossetia for thousands of years and had long enjoyed good relations with their Georgian neighbors.

Are these communities neighbors to each other? Or, are they guest and host communities? These divergent conceptions of what these communities are to each other shape current relations between Georgians and South Ossetians. Conflictual relations have emerged from these divergent conceptions, and from power politics that have exploited these divisions.

The inter-community relationship has developed over time. During the Soviet era, significant intermarriage between South Ossetians and Georgians built cross-community connections (Nan 2010, 243). Tensions escalated during perestroika as nationalist movements grew throughout the Soviet Union. As Georgia sought independence from the Soviet Union, South Ossetia sought greater autonomy within Georgia, as well as greater Ossetian language rights. On April 9, 1989, violence broke out in Tbilisi, Georgia's capital, as Soviet troops dispersed a Georgian independence demonstration, killing 21 people. That same year, South Ossetian protestors decried Georgian oppression of South Ossetian culture and language, and some considered 
unifying with North Ossetia (Nan 2010, 243). ${ }^{1}$ In Georgia, supporters of independence activist Zviad Gamsakhurdia carried signs that read "Georgia for Georgians." In Fall 1989, South Ossetian authorities first voted to secure the place of Ossetian language in South Ossetia, but Georgian authorities rejected their moves. Then, South Ossetian authorities voted to increase South Ossetia's autonomy within Georgia, but days later Georgian authorities rejected that vote as well.

Tensions escalated. Approximately 15,000 Georgians marched toward Tskhinval(i), the South Ossetian capital, on November 23, 1989, announcing their intention to demonstrate in the central square, but South Ossetians stood and blocked their way on the road, and Georgians held a demonstration in the outskirts of Tskhinval(i) instead ("Timeline of GeorgianOssetian Conflict (1989-2008)" 2020).

That confrontation ended without bloodshed, but tensions continued to simmer, and in 1990 criminal activities, including murder, exacerbated ethnic strife. And in June 1990, the Supreme Soviet of the Georgian Soviet Socialist Republic created a legal mechanism for the re-establishment of Georgia's independence. Shortly thereafter, on August 10, 1990, South Ossetians issued a declaration of sovereignty, followed by a September 20, 1990, decision to transform the Autonomous District of South Ossetia (within Georgia) into a Soviet Democratic Republic of South Ossetia (outside Georgia). The next day, the Supreme Soviet of the Georgian Soviet Socialist Republic refuted the South Ossetian decisions. On October 28, 1990, Georgia held multi-party elections that voted out the Communist Party, and voted in the coalition "Round Table: Free Georgia," but the majority of ethnic Ossetian citizens of South Ossetia boycotted the elections. On November 14, 1990, the Georgian Supreme Soviet elected Zviad Gamsakhurdia its chairman. When Georgia declared independence in 1991, Gamsakhurdia was elected President.

All this laid the groundwork for war. In January 1991, Gamsakhurdia sent official Georgian troops to South Ossetia, as opposed to the irregular armed groups that had previously demonstrated. This was the first large-scale conflict between formally organized and officially sanctioned troops and the South Ossetian resistance. Fighting continued sporadically as the Soviet Union faced political turmoil, including a coup in August 1991. With the dissolution of the Soviet Union in December 1991, Eduard Shevardnadze resigned from the position of Minister of Foreign Affairs of the U.S.S.R. In January 1992, Gamsakhurdia was deposed in a bloody coup in Georgia and in March 1992, Shevardnadze became leader of the Georgian parliament. As leader of the newly independent Republic of Georgia, Shevardnadze signed the Sochi Agreement with Russian President Boris Yeltsin in June 1992, establishing a ceasefire in the Georgian-South Ossetian context.

From 1992 through until 2008, there was minimal fighting in that region. Russian troops served as a Commonwealth of Independent States (CIS) peacekeeping force along the ceasefire line. 
Then, in summer 2008, tensions escalated and finally erupted into the August 2008 war. Multiple versions of the August war circulated online and in news media, so in December 2008 the European Union commissioned Heidi Tagliavini to lead an Independent International Fact Finding Mission on the Conflict in Georgia ("Independent International Fact Finding Mission on the Conflict in Georgia: Report" 2009). The resulting September 2009 report noted,

The shelling of Tskhinvali by the Georgian armed forces during the night of 7 to 8 August 2008 marked the beginning of the large-scale armed conflict in Georgia, yet it was only the culminating point of a long period of increasing tensions, provocations and incidents. (p. 11)

Russian forces quickly activated and struck back. French President Nicholas Sarkozy, who in July 2008 had taken on the rotating chair of the European Union Council, negotiated a ceasefire that was signed five days later, on August 12, 2008, with Russian President Dmitry Medvedev and Georgian President Mikhail Saakashvili.

Two wars changed the conflict irreversibly. The violence exacerbated existing issues and added new issues that continue to challenge the Georgian-South Ossetian relationship, making the role of peacemaking more challenging. Where there had been struggles for identity, cultural survival, and sovereignty, there now emerged post-war issues of trauma and trauma healing, refugees and Internally Displaced Persons (IDPs), prisoners, missing persons, ceasefire line administration and trespass, and divergent and divisive interpretations of issues such as genocide and Russian occupation. Both Abkhaz and South Ossetians found that war had sown even deeper distrust of Georgians (Garb 2009). South Ossetians called for an investigation of the Georgians' attempted genocide against them, citing incidents in the August 2008 war in which Georgians targeted fleeing civilians. Georgians condemned Russian occupation of Georgia, citing the growing Russian military base in Tskhinval(i) and the post-ceasefire expanded Russian military presence in areas of South Ossetia that had been under Georgian control prior to August 2008.

As this brief description suggests, many Georgians see the political context as dominated by the region's larger neighbor, Russia, and its long history of dominating Georgia. This domination occurred centuries before the Soviet era, during the Soviet era, and after that era, with Russia's occupation of Georgia in recent years. Similarly, many South Ossetians see the political context as dominated by their larger neighbor Georgia, and its long history of dominating South Ossetia, before and during the Soviet era, and then in genocidal fighting after the breakup of the Soviet Union. These disparate understandings make for a complex peacemaking context.

Add to this already complex picture the tense relations between Russia and the West. The relationships between the Georgian-South Ossetian 
conflict and the Russian-western confrontation in the region are worth remembering while reading further. Chapter Five discusses the nested model of conflict presented by Moire Dugan (Dugan 1996). We return to consider the connections between Russian-Western confrontation and GeorgianSouth Ossetian conflict then. The related yet distinct conflicts call for related yet distinct peacemaking processes.

\section{Georgian-South Ossetian Peacemaking}

The task of peacemakers, following Boutros Boutros Gali's definition, is to resolve underlying issues that provoke conflict. Pragmatically, peacemaking in the Georgian-South Ossetian context has meant making pieces of peace working incrementally, and step by step, to engage with issues where the parties have openness to engage, and leaving aside issues that the parties are not ready to engage. Indeed, part of the work of peacemaking is to build the parties' readiness to engage on more issues. When Georgians and South Ossetians are willing to discuss an issue, that discussion in and of itself shows that it is possible to work on the issue. These conversations and the range of issues engaged have changed over time.

In December 2008, four months after the August 2008 war, my colleagues and I convened Georgian and South Ossetian civil society peacemakers for a discussion at Point of View, the conflict resolution research and retreat center at George Mason University, just south of Washington, DC. I worked with Paula Garb, an anthropologist then based at the University of California at Irvine who was originally from the United States but had spent 20 years in the Soviet Union; Lara Olson, a Canadian who had worked on Georgian-South Ossetian conflict resolution initiatives in the 1990s with the Norwegian Refugee Council and Conflict Management Group; and Ekaterina Romanova, a Russian doctoral student at what was then the School for Conflict Analysis and Resolution and is now the Jimmy and Rosalynn Carter School for Peace and Conflict Resolution at George Mason University. In December, we began what participants named the Point of View process, in honor of the place where we first met. The process became a project of the Center for Peacemaking Practice within the School for Conflict Analysis and Resolution.

Over time, our approach shifted as the conflict dynamics shifted. Some years after launching the Point of View process, as detailed in the pages that follow, we changed focus to work on what we called the Cost of Conflict process, which integrated more scholarly analysis into the process. And, more recently, we shifted to the Value of Dialogue process, which puts emphasis more on peace than on conflict. While the same core people have worked together for over ten years, the focus of the processes has shifted, as indicated by the renaming.

These processes worked on pieces of peace, doing peacemaking to address some of the issues, but leaving the political status question aside. Our work 
contributed to the repair of Zonkari Dam, a large concrete dam high in the mountains, which we joke is one of our most "concrete" achievements. From that, we shifted to support discussions about sharing the irrigation water that flows from the dam. In 2010 we helped re-start the meetings of the Incident Prevention and Response Mechanism (IPRM), a series of monthly meetings in an EU tent at the ceasefire line to address local issues. We helped stimulate a more streamlined process for the International Committee of the Red Cross (ICRC) to get permission for ambulances to cross the ceasefire line for emergency trips to the nearest hospital. We contributed to the release of 16 prisoners in 2016 from Abkhaz, South Ossetian, and Georgian prisons. And, bringing together many other people associated with the peace process, from international governmental and nongovernmental organizations as well as local authorities and civil society, we stimulated many new confidence-building measures and supported coordination and complementarity among these various initiatives.

Some observers from farther away have said there has been no GeorgianSouth Ossetian peacemaking. They are not aware of the less formal or visible local work described in this book. Others, aware of local work but focused only on a final political settlement, have suggested that progress is not possible in the current context. Some have pointed to the Russian influence over South Ossetia and argued that the only meaningful conversations would be between Russia and Georgia, and some have called South Ossetia a puppet regime. Others view the settlement of South Ossetia's political status as the only goal of the peace process. These views all overlook the progress to date, which is creating a context in which more progress is possible tomorrow. Certainly, we will not have a final political settlement today, or even tomorrow or next month. But each day peacemakers can do something to build trust, address specific humanitarian needs, heal past traumas, and develop the ability to work together across divided communities. Those steps contribute to incremental peacemaking progress. And when peace is possible, we have an obligation to build it. Lives depend on that effort.

Close colleagues have challenged us to go further with our peacemaking by directly tackling questions about the current or future political status of South Ossetia as part of our work. The Georgian and South Ossetian coordinators of these unofficial processes do engage in trusted and confidential conversations between themselves, to make sense of the current realities and consider what might happen in the future. The political status of South Ossetia is part of those private conversations. They have an agreement to disagree on political status. While they have built the relationships that allow for such sensitive conversations, Georgian and South Ossetian coordinators do not believe it would be constructive in the current climate to have public debate over what the status of South Ossetia "should" be. Rather, we can continue our peacemaking by focusing on issues that are not as politically charged, and make progress one issue at a time. Georgian and South Ossetian peacemakers and I feel that we are laying the foundation for 
constructive consideration of the political status issues in the long-term future, once trust has been rebuilt through work on humanitarian issues and diverse confidence-building measures.

Does this incremental approach to peacemaking support the status quo? No. While the question of formal political status has not been resolved in over a decade of such peacemaking, there have been changes, such as those described above, that shape the experiences of people living in the conflict region. These changes are meaningful to the people who now have irrigation water, access to a nearby hospital, and have seen their loved ones return from imprisonment across the ceasefire line. Local partners are convinced that insisting on conversations to reach agreement about the political status of the region would have failed and all but ensured the breakdown of the peacemaking process.

Nor does the incremental approach to peacemaking reward aggressors. While it does not provide the political status settlement that the involved parties seek, the incremental approach foregrounds the needs of people living in the region. The peacemakers' rationale that undergirds this perspective will become clear in the pages that follow.

First, we pause to consider how we learn about peacemaking. How do we build understanding from experience? The next chapter considers how practice builds theory.

\section{Note}

1 As explained in the preface, I used the name Susan Allen Nan 1995-2014, and used Susan Allen before and after that period. When citing Susan Allen Nan, I am citing my own work.

\section{Works Cited}

Dugan, Maire A. 1996. "A Nested Theory of Conflict.” A Leadership Journal: Women in Leadership- Sharing the Vision 1 (July): 9-20.

Garb, Paula. 2009. "The View from Abkhazia of South Ossetia Ablaze." Central Asian Survey 28 (2): 235-46. 10.1080/02634930903034856.

"Independent International Fact Finding Mission on the Conflict in Georgia: Report." 2009. IIFFMCG. https://www.echr.coe.int/Documents/HUDOC_38263_08_Annexes_ ENG.pdf.

Nan, Susan Allen. 2010. "The Roles of Conflict Resolution Scholars in GeorgianAbkhaz and Georgian-South-Ossetian Conflict and Conflict Resolution." Cambridge Review of International Affairs 23 (2): 237-58. 10.1080/09557571003745856.

"Timeline of Georgian-Ossetian Conflict (1989-2008)." 2020. Timeline. Institute for the Study of Nationalism and Conflict. https://www.sutori.com/story/k-art-ul-osurikonp-lik-tis-droit-i-crp-ivi-1977-2008--746R3FMiftYruKBSnkEUAodd. 


\section{Practice Builds Theory}

In 2010 I worked with Andrea Bartoli, Zachariah Mampilly and many peacemaking practitioners to author a two-volume book entitled, Peacemaking: From Practice to Theory (Nan, Mampilly, and Bartoli 2011). When I mentioned the title to a colleague, he assumed that I had misspoken and replied, "You mean from theory to practice?" We meant from practice to theory. This was another reminder that the methods of developing theory from practice are unfamiliar to many.

Richard E. Rubenstein explains (Rubenstein 2020) that "people 'do' theory all the time without knowing it, like the character in one of Moliere's plays who discovered, to his surprise, that he had been speaking prose all his life." Aristotle and other ancient Greek philosophers identified phronesis, a form of wisdom related to practical action. For Aristotle, this practical knowledge was derived from experience (Aristotle 2011). In valuing phronesis, we value peacemakers' practical knowledge, born from experience. Argyris and Schon argue there are both espoused theories that practitioners articulate to describe their work and also theories-in-use, which may be subconscious, and which may guide practitioners subconsciously (Argyris and Schon 1974). All of these forms count as theory in this book.

In the conflict resolution field, some theories engage with conflict resolution generally, looking at what works, or even exploring more deeply the definition of "resolution." Others focus on specific kinds of conflict resolution, and theorize how they work. Some of these focus on theories of practice. And some theories do not consider conflict resolution at all. There are theories focused on analyzing conflicts, without considering resolution. Each theory sets out to address its own specific questions.

Rothbart (Rothbart 2021) presents conflict research as reflective praxis. He explains (p.1): "Such praxis is an objective inquiry that is inseparable from the moral-political imperatives for providing conflict actors with a liberating power to suppress, circumvent or overcome the forces of violence and injustice that engulf them, their adversaries and the innocents caught in the cross-fire." In other words, the field of conflict analysis and resolution is charged with moral and political meaning. People engaged in praxis seek to 
address conflicts and their accompanying problems. Peacemaking practitioners are, quite simply, trying to make the world a better place.

This book presents theories of peacemaking and embraces the normativity the judgement that peace is better than deadly conflict - found in peacemaking. Theories of conflict and conflict resolution, including peacemaking, have different emphases. The former, theories of conflict, try to explain why conflicts occur, and the latter, theories of conflict resolution, focus on ways to resolve conflicts.

A theory can be evaluated by criteria other than its predictive accuracy. Dugan clarifies the value of understanding the positionality and method behind theory: "Theory is usually presented in a way that is overly objectified. There is rarely an 'I' in a theoretical treatise. The theorist remains unknown as a person. How he developed the theory is a mystery..." (Dugan 1996; p. 10). With Dugan's insight in mind, where possible in this book I present peacemakers' positionalities in relation to their peacemaking practice. The book also returns to the nested model of conflict that Dugan developed through her theory building from practice, with further discussion of it in Chapter Five.

By "practice" I mean engaging in the world to try to enact some change. In the context of this book, practice is doing something intended to resolve a conflict. This may include any action to support sustainable peace, address humanitarian concerns, pursue justice, develop a signed peace agreement, or any other contribution intended to help resolve a conflict.

For some time, the foreign policy and international affairs fields have identified a divide between theory and practice as a problem, and have sought to bridge the two. Alexander George wrote Bridging the Gap: Theory and Practice in Foreign Policy (1993) to address the divides between the worlds of theory and practice in foreign policy. International Studies Review devoted a special issue of the journal (Volume 13, Issue 1) to the subject of "Theory vs. Practice" (Weiss and Kittikhoun 2011). In 2014, the Carnegie Corporation of New York announced a $\$ 5$ million grant program called "Bridging the Gap" to unite "academia and policy" in international affairs ("Bridging the Gap: Carnegie Corporation of New York Awards \$5 Million to Universities for Innovative Programs Linking Academia and Policy” 2020).

This gap between theory and practice remains a concern in the broader international relations field, and for some within the field of conflict resolution specifically, but conflict resolution also has a long tradition of scholars and practitioners who work closely together, and of "scholar-practitioners"- individuals who are both scholars and practitioners of conflict resolution. In his work, Kelman describes the specific role of scholar-practitioners in interactive problem-solving - a specific form of conflict resolution practice (Kelman 2000). In a previous article, I discussed the many roles of scholars and scholarpractitioners in conflict resolution in the South Caucasus, highlighting the dilemmas of moving between the roles of advising conflict parties, facilitating among them, and analyzing the conflicts (Nan 2010). 
While there are multiple ways to engage as scholars in conflict contexts, some of these ways are incompatible with others. For example, this book is the most I have ever written on the Georgian-South Ossetian conflict and conflict resolution process, as I have sought to very clearly maintain my impartiality by not taking sides in any way. For that reason, this book focuses on the peacemaking process, while providing only minimal orientation to the relevant conflict contexts. If I were to present a political analysis of the conflict and sovereignty issues in dispute, at least one and probably more parties to the conflict would be disappointed to see an analysis that does not only support their side's positions.

University professors in the United States who are or were conflict resolution scholar-practitioners include: Doris Allen, Rochelle Arms Almengor, Eileen Babbitt, Sara Cobb, Tamra Pearson D'Estree, Jayne Docherty, Roger Fisher, Ronald Fisher, Mari Fitzduff, Philip Gamaghelyan, Paula Garb, Marc Gopin, Herbert Kelman, John Paul Lederach, Kurt Lewin, Christopher Mitchell, Arthur Romano, Lawrence Susskind, and Wallace Warfield, among many others. A 2011 symposium of U.S. based scholar-practitioners to address the place of practice within the academy revealed that scholarpractitioners in the United States look for their validation from the conflict parties they work with and in the practical results of their work more than from the academy and scholarly citations of their work (Avruch and Nan 2013). Globally, scholar practitioners in the field may find more support in both university-affiliated entities and NGOs such as Conciliation Resources, International Alert, IndiePeace, the Peace Research Institute of Oslo, Stokholm International Peace Research Institute, Tampere Peace Research Institute, Berghof Foundation, Peaceful Change Initiative, Center for Humanitarian Dialogue, etc.

In any event, despite the existence of scholar-practitioners, the preoccupation with the gaps between theory and practice distract our attention from their inseparability; that is, from theories and insights that are generated and exist within the world of practice. Conflict resolution practitioners engage theories that drive their work, as this book illustrates in the Georgian and South Ossetian peacemaking efforts, Estonian-Russian peacemaking, and beyond. As practitioners seek to do effective conflict resolution work, they want to know what is effective in their particular circumstances and context. These questions are of paramount importance to conflict resolution practice, and thus animate theories in practice.

This rest of this chapter identifies theories in practice and ways of learning through practice with reference to Georgian and South Ossetian peacemakers. These insights and epistemologies will inform the rest of the book. Rice foresaw theories in practice would become increasingly important: "The scholarship of engagement... will require the greatest change in our thinking about what counts as scholarship" (Rice 2006, p. 13).

Although they overlap, four main research approaches or methods have guided the inquiry that peacemakers working in the Georgian-South 
Ossetian context have done together over the last decade. 1) Engaged scholarship (Boyer 1996) is research that seeks to contribute to solving problems. 2) Reflective practice (Arms Almengor 2018) helps practitioners systematically make their theories in use more explicit. 3) Evaluation (Elliot, d'Estree, and Kaufman 2003) is a systematic effort to learn from experience. And, 4) Action research (Bradbury 2016; Allen and Friedman 2021) directly addresses current social problems. These approaches build on and complement each other, and as a whole emphasize learning from experience. Each of these is discussed below, with examples of how Georgian-South Ossetian peacemakers and I engaged in versions of each of these at various times in our work together.

These approaches do not generate theory purely from experience, utilizing only bottom-up induction. Nor do they work purely through deduction, working top-down from other theories and logical consequences. Rather, through "abduction" (Peirce 2010, p.45), these approaches engage both reason and nature; both theories and practical experience, and learn through both. Lehti (Lehti 2019, p. 8) defines abduction, and his work theorizing peace mediation, this way:

Instead of predefining abstract theoretical frames for testing (deduction) or making conclusions on the basis of pure facts (induction), the abduction is the phenomenon-centric approach based on the hermeneutic circle in which collected empirical observations complement but also revisit the original conceptualization of a particular phenomenon, which in this particular case is peace mediation.

These abduction approaches of engaged scholarship, in collaboration with Georgian and South Ossetians peacemakers, have generated some theoretical knowledge of peacemaking practice focused on people, process (including partnership), and perseverance. This theory of engaged scholarship, reflective practice, evaluation, and action research emphasized Georgian-South Ossetian mutual understanding and the prevention of a return to violence over the decade. Experience shows that people make a difference, and that individual actions do matter as part of peacemaking, de-escalating conflict and preventing violence.

At the same time, coordination and partnerships are important as well. Complementarity amplifies the impact of several different peacemaking efforts to bring the strengths of various peacemakers to bear, including international and local partnerships, and partnerships between many internationals or many locals. By gathering insights from partners across the conflict divides we can gauge carefully how far to "push the envelope" or how to work within the boundaries of what is possible, as measured from all relevant perspectives. While working within those boundaries, we also push against them - gently, so as not to provoke a backlash. How do we keep going in the face of slow progress? Each bit of incremental change toward 
understanding and preventing violence is worth celebrating. Little shifts add up over time. The peace process develops over time as the context changes. Shared analysis of the context and peace process help guide the peacemaking work with insights from across the conflict divide.

These people, process, and perseverance theories both emerged from and guide the civil society-based peacemaking process in Georgia and South Ossetia. As described in the chapters that follow, these theories have emerged from and been tested over years of conflict resolution dialogues and related efforts by the peacemaking coordination team. The team knows from experience that these insights work in practice in the region.

\section{Engaged Scholarship}

Engaged scholarship is research that seeks in one way or another to address current problems. As Boyer defines it, "The scholarship of engagement means connecting the rich resources of the university to our most pressing social, civic, and ethical problems" (Boyer 1996). Boyer elaborates the directive: "The academy must become a more vigorous partner in the search for answers to our most pressing social, civic, economic, and moral problems, and must reaffirm its historic commitment to what I call the scholarship of engagement" (Boyer 1996). Engaged scholarship may be research requested by people facing problems, research that itself directly helps solve problems, or research that informs our understanding of problems.

In the conflict resolution context, engaged scholarship takes each of these forms. Researchers respond to requests by parties in conflict to examine particular questions. For example, Dr. Bruno Coppetiers convened a symposium on models of sovereignty when this issue was of practical interest to Georgian and Abkhaz policy makers (Nan 2010, p. 247). Research directly helps address conflicts when research is itself a confidence building measure, as when Georgians and South Ossetians met at a 2016 symposium in Vienna, convened by George Mason University, to consider the Cost of Conflict in the Georgian-South Ossetian context. And, research such as surveys in conflict regions (Toal (Gearóid Ó Tuathail) and O'Loughlin 2013) informs our understanding of current attitudes. In my examination of the work of scholars in conflict resolution in the South Caucasus from 1992 to 2008, I found both traditional academic roles (education and training, developing relevant conflict resolution theory drawing from empirical research, and analyzing conflicts based on the facts as the scholar comes to know them) and scholar-practitioner roles (advising conflict protagonists, conflict resolution practice and influencing international policy on conflict areas) (Nan 2010, p. 238).

Although for years there was only sparse scholarship about the GeorgianSouth Ossetian process, the process itself engaged scholarship as part of its activities. The Georgian and South Ossetian peacemakers coordinating group turned to engaged scholarship as a form of conflict resolution 
practice. They perceived that convening Georgians and South Ossetians for scholarly work was a safe form of engagement. We reasoned that no one would be accused of being a traitor for writing a scholarly article, or going to an international conference. In a context that already had a journal, Caucasus Edition: Journal of Conflict Transformation, that featured work by analysts from across the South Caucasus, the Georgians and South Ossetians sought to do work focused specifically on their relationship.

Our first specifically Georgian-South Ossetian publication was an edited collection, "Georgian-South Ossetian Conflict: Researching Peace" (Nan 2011c; 2011b). It included three articles by Georgian scholars, and three by South Ossetian scholars. The articles were printed such that to read the Georgian articles a reader would hold the book one way and to read the South Ossetian articles, a reader would flip the book 180 degrees. This allowed the articles to appear in the same volume, in one sense, and yet to be separated, in another sense. Not only did the articles have politically different orientations, they also had physically different orientations on the pages. And, by this format, neither group came first. Each part of the book was published by a different publisher: the Georgian articles by a Georgian think tank and the Ossetian articles by an Ossetian think tank. These are really two books in one physical collection. Whose articles appear first changes as the volume's orientation changes. As the reader flips the volume over, the other papers come first and become oriented appropriately to read. The volume served several peacemaking purposes: scholars built relationships as they presented their draft articles to each other; project coordinators built relationships as they implemented the project together; and readers learned new perspectives as they read articles from across the conflict divide.

Five years later, Georgian and South Ossetian analysts were ready for their articles to appear in one volume. In 2016, "Cost of Conflict: Core Dimensions of the Georgian-South Ossetian Context" was published by George Mason University and the Alliance for Conflict Transformation (Alborova, Allen, and Kalandarishvili 2016a). The volume contained articles by Georgian, South Ossetian, and international experts that each addressed some aspects of the human, institutional, and economic costs of the Georgian-South Ossetian conflict. This volume was presented and discussed in Vienna, Austria, at a symposium convened for that purpose. Diplomats stationed at the Organization for Security and Cooperation in Europe (OSCE) in Vienna participated in the symposium. It was an opportunity for South Ossetians, who rarely spoke to the international diplomatic community outside of the Geneva International Discussions, to present their perspectives. And, for diplomats, it was an opportunity to see constructive discussion between Georgian and South Ossetian experts who had developed a rapport and working relationship in the course of sharing article drafts and preparing the conference. Later that same year, a companion volume came out, focused on individual experiences of the conflict (Alborova, Allen, and Kalandarishvili 2016b). Journalists had interviewed 
people living on both sides of the ceasefire line and in this work presented their experiences of the war and its aftermath. This volume allowed readers to see the humanity of people on both sides who had suffered from the war and postwar context.

Engaged scholarship has proven effective in other contexts as well. Tatsushi Arai (Arai 2021) has produced significant engaged scholarship related to his practitioner experiences. His work has focused on contexts such as the East China Sea (Arai, Goto, and Wang 2013), Myanmar (Arai 2017), and Syria (Arai 2019). Canvassing the multiple contexts in which he has engaged, Arai notes the promising opportunities to learn from practice by studying different types of "artifacts" produced by peacemaking practice. For example, in his work over nearly two decades in "Strait Talk" dialogues, focused on the Taiwan Strait, multiple groups of young civil society participants from both sides of the Strait have mapped their history of the shared conflict (Arai 2015). Arai has collected both Taiwanese and Chinese timelines of conflict history over the years, and identifies patterns in the conflict development when he reviews this history of histories. The collection of histories created as part of dialogue processes is just one example of many possible enactments of Arai's idea that we examine the artifacts of peacemaking practice. This book is possible only because so many artifacts of Georgian-South Ossetian and other peacemaking processes have preserved insights into those experiences, whether in my notebooks or grant reports, or correspondence with partners.

\section{Reflective Practice}

As the coordinating group planned and implemented these engaged scholarship initiatives, we reflected on our work. What theories were guiding our work? We sought to articulate these in our coordinating group discussions as we made sense of our past work and planned our future work together. To the extent that we were able to articulate our theories, these appear in the pages of this book.

To recall, Argyris and Schon, argue that there are both espoused theories that practitioners articulate in describing their work and also theories-in-use, which may be subconscious, and which may guide practitioners subconsciously (Argyris and Schon 1974). Reflective practice is a systematic process that helps make our theories-in-use more explicit, and this is valuable because conflict resolution practitioners can make more conscious choices within their practice when they are more aware of the theories they utilize. And, when practitioners can express their theory in use, they can share these theories, built outward from experience. Theory-in-use clarification, in other words, builds theory.

Our partnership within the coordination team required that we be as explicit as we could about our theories that guided our choices. When faced with a decision, such as whether or not to invite a particular person to our next 
dialogue, we discussed the decision in terms that included reference to our theories. In this case, I recall one of the Georgian coordination team members articulating a theory that "you know your community better." The theory was that a South Ossetian coordination team member was better informed about South Ossetian society and thus had important information for making a decision about inviting a particular South Ossetian. Our partnerships within the coordination team were built around a respect for the knowledge each of us carried about their own society. With a ceasefire line that very few people could cross, we had to rely on each other for the nuanced, in-depth understanding of their respective home communities. Beyond discussion of a particular person's invitation, we were also explicit about how to make that decision, which allowed us to articulate the theory that each knows their home community better than people who are not immersed in that community.

In the course of group decisions within the coordination team, we also often considered how much risk to assume as we planned future activities. The group agreed with one of the theories I offered, which was that we want to "push the envelope without tearing it." In other words, we want to be aware of the boundaries of acceptable activities, and work at those edges, perhaps gradually expanding the boundaries but not so quickly or drastically as to provoke a backlash that would shrink the space for conflict resolution work. This work at the outwardly-expanding edges and this caution about working carefully so as not to provoke a backlash emerged as a guiding principle in our coordination team discussions.

The Georgian and South Ossetian coordinators and I would often reflect in our planning meetings, and the question "why" often stimulated these reflective discussions. We would seek to make sense of what had worked and what hadn't worked in our past initiatives. Likewise, questions about future plans stimulated reflective discussion. We would plan our future initiatives with the benefit of having learned from experience. While some of our planning meetings happened in person during the evenings or breakfasts that bracketed our dialogues, and some in person during coordination meetings, we also held many planning meetings by internet. The uncertain, shaky internet connection with our South Ossetian colleagues - we never knew how long the connection would last and sometimes could not hear each other fully - ironically may have been helpful to our reflective practice, because we developed a culture of speaking directly to our point, and articulating our theories clearly and quickly before the internet connection might be lost.

While reflective practice conversations were regularly part of how we made sense of the work and planned our future work, we also turned to more structured evaluation to deepen our learning and better inform our work.

\section{Evaluation}

Elliot, d'Estree and Kaufman define evaluation as "a systematic effort to learn from experience" (2003). Evaluation seeks to address a variety of questions, 
using appropriate research methodologies aligned with each evaluation's chosen questions and purpose. For the Georgian-South Ossetian team, our focus was on formative evaluation (Nan 2003) to improve our practice. We would assess our work, and adjust accordingly. Because the Georgian-South Ossetian process is long term, summative evaluation did not make sense in the middle of ongoing work. However, at the conclusion of one larger grant, we did conduct a summative evaluation as part of that project.

Despite the focus on formative evaluation, our efforts ranged from internal to external evaluation and from informal to formal evaluation at various times in our work. It was difficult to secure funding for evaluation. In only one larger USAID grant did we have sufficient funding for robust evaluation, such that we were we able to hire an external evaluator to work with us throughout the life of the project.

The evaluation process became an integral part of the conflict resolution process with the Georgian and South Ossetian team. The evaluation discussions were simultaneously conflict resolution discussions. When Georgians and South Ossetians together assessed and analyzed their shared conflict and articulated the goals of their work, they were increasing their understanding of each other's perspectives on what we were doing, why we were doing it, and how we were doing it. I had worked with Jay Rothman during the development of action evaluation (Rothman 2007) in 1999 and 2000, when I served as the action evaluator for Georgian-Abkhaz dialogues convened by Dr. Paula Garb of the University of California at Irvine. Later, my engagement with Georgians and South Ossetians was naturally influenced by my experience with action evaluation with Georgians and Abkhaz.

With action evaluation as a model, and with funding scarce for an external evaluator, most of our evaluations were internal, and conducted together as a coordination team. Sometimes we collected feedback on written surveys from participants in dialogues; at other times we spoke with participants individually to elicit their feedback. The coordinating team considered these responses and insights as it planned next steps. We generally wrote very simple evaluation reports to donors as part of our project reporting.

In our evaluation reports we highlighted specific, tangible outcomes from the project that we viewed as significant. Often, our meetings catalyzed other initiatives. I coined the term "catalytic workshops" to refer to the workshop design (further discussed in Chapter Four) that stimulated the creation of further confidence building measures. We highlighted these new confidence building initiatives in reports to donors, and also cited specific, official-level initiatives considered in the Geneva International Discussions process to which our efforts had contributed in some way, including repair of the Zonkari dam, release of prisoners from all sides, resumption of the Incident Prevention Response Mechanism (IPRM), cleanup of trash in the irrigation channel, and a streamlined process for ambulances to cross the ceasefire line.

From 2014 to 2016, we had the USAID funding that allowed us to hire an external evaluator, Lara Olson. She had had experience working in the 
South Caucasus region, and had a flexible schedule as a doctoral student, so she could work part-time as the project's evaluator. Some parts of the larger project were sub-contracted to others; for example, a Conciliation Resources team that worked independently on the Georgian-Abkhaz relationship. Olson, however, served as the external evaluator for the entire project. We asked Lara to work with a developmental evaluation (Patton 2011) model, in which evaluation is designed to help a long-term project develop over time, responding to changes in the context and shifting plans as necessary. We asked Lara to help us adapt to the changing conflict context over the two years, as elections were held in Georgia, and Russia cracked down on dissent in the Caucasus region while preparing for the Sochi Olympics. And, adapt we did. For example, during the larger USAID project one of our partners tried to bring South Ossetian students into an online course to work alongside Georgian and Abkhaz and American students. However, we discovered that very few South Ossetian students had the necessary combination of excellent English language skills, fast internet connections, and interest in the course, and thus by the second year we did not include South Ossetian students in the course. However, we did advocate for improved internet and access to English language courses in South Ossetia.

The internal and the external evaluation approaches both had pros and cons. Internal evaluations committed the coordinating team to regular periodic reflections on what we were learning and how we could improve. We considered changes in the conflict context as we planned next steps. However, we did not do this as methodically on our own as we did when we worked with Olson as our external evaluator. Lara asked us to set aside time in our monthly coordination calls to focus on evaluation. Rather than rushing through the evaluation, we focused on topics she had prepared for discussion. Furthermore, we sent reports every two weeks to each other, to Lara, and to our funder, USAID. Evaluation was a constant part of our work. This made the evaluation much more intensive. It allowed the evaluation to shape our work more deeply as well. For example, we shared a full day in Istanbul with Lara facilitating our team analysis of the then current context and how our work could best diminish the likelihood of war breaking out again.

\section{Action Research}

Action research brings together "action and reflection, theory and practice, in the pursuit of practical solutions to issues of pressing concern" (Bradbury 2016, p. 1). Action research is a way of working with various stakeholders to solve shared problems by engaging research as part of that effort. Since Kurt Lewin's signal work, "Action Research and Minority Problems" (Lewin 1946), action research has been recognized as an approach relevant for engaging with conflicts. In contrast to research on people doing conflict resolution work, 
action research does research with people doing conflict resolution work. According to Allen and Freidman, "Action research takes place through democratized, open-ended, iterative and reflective processes in which the questions, design, and conclusions of the research emerge though collaborative learning" (Allen and Friedman 2021). Recent action researchers have innovatively enriched conflict resolution practice (Gamaghelyan 2017) and have utilized participatory action research as a form of conflict resolution practice (Elder 2016).

Action research, broadly understood, has guided coordinators who convene Georgian-South Ossetian dialogues since the fall of 2008, when Georgian and South Ossetian peacemakers met at George Mason University's retreat facility to begin the dialogue that came to be known as the Point of View process. That process engaged officials from both sides, including Ministers and official negotiators at the Geneva International Discussions (GID), and at the Incident Prevention and Response Mechanism (IPRM); advisors of GID co-chairs and one of the co-chairs; civil society peacemaking leaders; journalists; academics; policy advisors; and grassroots peacemakers. Georgian and South Ossetian peacemakers and I formed a coordinating team to continue the Point of View process and related initiatives. We then convened over twenty Point of View follow up meetings that contributed to ideas implemented by GID or IPRM participants.

As a research team we wanted to figure out what conflict resolution work might effectively improve the Georgian-South Ossetian relationship. We accomplished this by assessing the situation, trying various approaches, and adapting over time as we learned what worked. In a sense we were researching what would constitute effective peacemaking in this context. For much of our "research" we simply listened to each other's insights. Some members of the team had in-depth understanding of South Ossetian society, since they lived there and spoke with their friends and neighbors, and others had similar understanding of Georgian society, for the same reasons. We needed each other to plan our next steps with a better understanding of what might work to engage both societies constructively. We learned how that worked by trying it out. Then we adjusted our plans based on ongoing evaluations.

Action research has been embraced generally by the conflict resolution field, with its strong normative commitments to preventing and reducing the death and destruction of war and to building positive peace and justice. Among other examples that include some of the same elements described for the Georgian-South Ossetian context, the Life and Peace Institute has engaged Participatory Action Research (PAR) as a peacemaking approach in the Democratic Republic of Congo since 2007, and in south central Somalia since 2008, with the Zamzam Foundation. The PAR engagement in south central Somalia is well documented and was evaluated, ironically, by an outside evaluator. Research consultant Claire Elder authored a Life and Peace Institute report that summarizes several years of the action research 
initiative in south central Somalia (Elder 2016). The report includes process descriptions of how action research teams worked through various phases of the initiative. Such accessible documentation of action research as peacemaking practice is rare. The report presents a glimpse into the processes of that specific peacemaking practice in Somalia.

\section{Toward an Epistemology of Theories in Practice}

We know there are both constraints and opportunities for practicing conflict resolution in academic settings (Avruch and Nan, 2013). Building on the Georgian-South Ossetian peacemaking experience and that of other scholarpractitioners, this book deepens our understanding of the constraints and opportunities for conducting research in the context of conflict resolution practice.

\section{Opportunities: Learning Relevant to Practice}

Research in conflict resolution practice contexts offers opportunities to address questions highly relevant to practitioners. Arms Almengor highlights the role of reflective practice in developing knowledge (Arms Almengor 2018, p. 21):

Reflective practice is one of several learning orientations that consider a practitioner's experience (learning through doing) as a legitimate and effective way of generating knowledge and theories. As such, it is an epistemology of practice, a theory of knowledge that relies on practice as its method of discovery and validation.

For example, my work on consciousness and conflict resolution (Nan 2011a) emerged from reflective practice engagement with decades of conflict resolution experience, guided by both experience and conversation with other practitioners and scholars who raised important questions about the core engagement of consciousness in conflict resolution practice.

Peacemaking practice points out key questions to guide peacemaking research. Peacemaking work that engages authoritarian societies leads to questions about how to do peacemaking where space for engagement is extremely limited. This can guide research, given that theory on peacemaking until recently has not focused on work in authoritarian societies. Practical efforts to operationalize peacemaking in areas with authoritarian tendencies compelled practitioners to learn approaches that might be successful in such environments. In turn, the practice revealed an area that had received scant attention in theory. This spurs research on peacemaking practice in these contexts, offering tentative guidance for others working in other authoritarian societies. Practice helps pose questions that lead to relevant research with pragmatic uses. 


\section{Opportunities: Learning by Doing}

We have only a limited capacity to learn about a conflict situation and the people involved in it when the learner engages only for a short time and from afar, by reading books, articles, and news. In contrast, long-term, hands-on work in a conflict resolution process brings an appreciation and understanding of:

- The individuals involved in the conflict resolution process and their worldviews, including their sense of constraints, hopes, histories, and worries

- Changes over time in their experiences

- Their sense of the possibilities for change in the conflict dynamics or in their society

- The possibilities they see for future arrangements, even decades in the future

\section{Opportunities: Listening and Learning}

So much published work focuses on political dynamics, the power elite, and the news as reported by media. Inevitably, these become lenses through which we view conflicts. When I listen to Georgians and South Ossetians tell each other what is important for the other to understand about their experience, I learn things that are not usually written in published analyses of the conflict and the conflict resolution process. For example, I learned something of the depth of the conflict when a South Ossetian woman told me tearfully about how hurt she was when she heard Georgians calling South Ossetians guests in their own homeland, and then I learned more just days later over a cup of tea, when a Georgian woman sighed and shook her head, mystified that South Ossetians do not appreciate that Georgians have always treated the South Ossetians as honored guests. The Georgian woman emphasized the honoring of the guests, without realizing that calling South Ossetians guests was a deep insult to them. Each of these women shared their stories with me, presenting what each saw as most important to share. People living the conflicts perceive them through their own lenses, and they are rarely the ones used in formal politics or the media. When I learn from them directly, over time, I begin to develop an understanding of their perspectives that more closely resembles "thick description" (Geertz 1973).

\section{Opportunities: Holding Tensions and Complexity of Practice}

Developing theory in practice demands that we embrace tensions between concepts, rather than assigning primacy to one concept above all. Scholar practitioners have explored the complexity of practice and yet still manage to theorize in a way that highlights key elements of the practice. For 
example, John Paul Lederach writes of the dance between truth, mercy, justice, and peace that contributes to reconciliation (Lederach 1999). Marc Gopin presents "compassionate reasoning" as a paradoxical approach that combines both compassion and reason to resolve conflict (Gopin 2019). Theory building in contexts of practice affords us an opportunity to bring together multiple layers of conflict (Dugan 1996), bridging structural, institutional, personal, cultural, and various other aspects of conflict together. Peacemaking practice requires multidimensional theory.

\section{Opportunities: Different Methodologies Address Different Questions}

We know from research methods experts that different kinds of research questions require different kinds of methodologies to address them. If we want to know about the general trends in peace agreements after secessionist or self-determination wars, we look to a large- $\mathrm{N}$ study of germane peace agreements, reviewing their characteristics. If we want to know if a certain intervention usually causes a certain outcome then we can do an experimental or, in the case of real-world conflict-resolution processes, a quasiexperimental design study to look for indications of causality.

Action research and other forms of engaged scholarship help address specific kinds of questions. These questions tend to be directly relevant to practice in that context. And this research can raise important questions for consideration by practitioners and theorists looking at other contexts.

\section{Opportunities: Validity}

When we build from practice to theory, validity is based on what works in practice. Engaged scholarship, action research, evaluation, and reflective practice in conflict resolution is validated when we see social change that supports conflict resolution and self-awareness of our actions and their impact. Utilizing a recursive and process-focused validity (Cho and Trent 2006) highlights connection of the means and ends of research. Lather argues for "research designs that push us toward becoming vigorously selfaware" (Lather 1986, p. 66). Building from practice to theory demands what Lather describes as catalytic validity in openly ideological research. She describes approaches to validity that are appropriate for social change efforts such as conflict resolution, emphasizing catalytic validity. Catalytic validity refers to the impact research has on catalyzing social change. The catalytic validity of engaged scholarship, action research, evaluation, and reflective practice can be seen when these forms of research promote conflict resolution. At the same time, it is a challenge to find the balance between validity measured by constructive change on the one hand and, on the other hand, validity measured as engagement that does not eventually promote a backlash by political leadership or society. In other words, this work strives for validity in long-term positive impact. 


\section{Practice Builds Theory}

\section{Challenges: Confidentiality of Ongoing Practice}

In the case of South Ossetia, keeping certain conflict resolution work quiet may be necessary to keep that work possible, while making it public might both increase the short-term societal impact of the initiative but also promote a long-term backlash from the leadership in South Ossetia. This dilemma between keeping work confidential and making it public constrains the possibilities for research.

Because much of the engagement with South Ossetians for peacemaking has been kept purposefully quiet in recent years, there is a myth circulating around Tbilisi, particularly within the international donor community, that it is impossible to work with South Ossetians on confidence building. This is an exaggeration, based on lack of knowledge of the existing peacemaking work. It is difficult, and it is challenging, but there are people (myself and partners included) who are working with South Ossetians on confidence building programs.

\section{Challenges: Acknowledging Each Conflict IS Unique, and We CAN Learn from Broad Trends}

Research in the conflict resolution field speaks both to people living in one specific conflict and also to people working to address conflicts generally. The field needs both generalized and specific knowledge. And, the field needs to keep in context the utility and constraints of each type of knowledge and to make space for individual agency even within broad trends. From the perspective of people living a conflict situation, a cursory review of their experience that reduces it to a few variables does not begin to do it justice, and is not useful to them as they plan the way forward in their own context. But a study that brings out generalized knowledge of a particular kind of conflict dynamic can offer guidance to individuals engaged in a specific case and conflict dynamic. Still, if conflict parties who are steeped in their own conflict were to review the results of a large- $\mathrm{N}$ study of a particular kind of conflict, they would not see a key factor of their own experience reflected in that study: People who are shaping their own conflict dynamics know that individuals can make a difference. They have seen individual choices shape the conflict dynamics. Conflict protagonists can learn from larger trends and yet they also know that larger trends do not amount to a preordained fate. Conflict protagonists can shape their futures, despite larger trends. Peacemakers have agency with which to engage the trends.

\section{Challenges: Abstraction and Contextual Experience}

My Carter School colleague Professor Daniel Rothbart has suggested that the reliance on social scientific theory for peacebuilding - including conflict theory - raises an epistemic paradox (Rothbart 2021). On the one hand, a theory constitutes an abstraction that is far removed from the immediacy of 
contextualized experience. The theory in effect suppresses some properties while it accentuates others. On the other hand, practitioners work in the moment in a specific context, and develop theory in practice that essentializes part of their experience. Apropos Rothbart's comments I question why practitioners do this. Why do we theorize from more complex experiences to produce more simple stories? This returns us back to the goal of scholarship, and the normative component of peacemaking practice research: we seek to improve peacemaking. While the full complex stories of peacemaking practice would present more of the immediacy of specific experiences, they would not spark reflection on other experiences in the way that theory can. By stripping away some of the experience to focus on others, we find focus that can guide us in similar contexts in other times in the future. In weaving between presenting theory and stories of peacemaking practice, this book attempts to bridge the worlds of abstraction and context. We need both. This is a challenge of developing practice from theory.

\section{Challenges: Writing and Doing}

This project is significant for the conflict resolution field because we have few long-term case studies of action research in conflict resolution. Practitioners too often are not able to take the time to write about their practice, and academics too often move from conflict to conflict without writing long-term, in-depth case studies. Writing is also a form of doing. Sharing the experience of the Georgian-South Ossetian process can both shape the next stages of that process as the people involved read the book, and can shape the theories of this field and offer some insight for other conflict resolution processes.

To explain this book's emphasis on learning from practice, I find Dugan's approach to theory and theory building relevant. She writes, "I think that the theory I am presenting in the following pages may be less important than the story of how I came to develop it" (Dugan 1996, p. 10-11). Indeed, while peacemaking insights may be helpful to those doing peacemaking, the processes of learning from practice can be helpful far beyond the peacemaking arena. We are all theorists, learning from our various experiences, and building capacity to address so many different problems, not only problems of conflict.

Dugan presents insights into her own story as she explains how she developed the theory of nested conflict. The next chapter presents personal stories of several peacemakers, providing some understanding of who was involved in developing the insights offered here, and their positionality, since understanding these theories requires understanding who developed them.

\section{Works Cited}

Allen, Susan H. 2017. "Who Rebuilds? Local Roles in Rebuilding Shattered Societies." In Rethinking Humanitarian Intervention in the 21st Century, edited by Aiden Warren and Damian Grenfell, 267-286. Edinburgh: Edinburgh University Press. 
Allen, Susan H., and Victor J. Friedman. 2021. "An Emerging Conversation between Action Research and Conflict Transformation." Action Research 19 (1): 3-8. 10.11 77/1476750320972485.

Arai, Tatsushi. 2015. "Engaging Conflict History: Toward an Integrated Method of Conflict Resolution Dialogue and Capacity Building." Conflict Resolution Quarterly 32 (3): 277-298. 10.1002/crq.21113.

Arai, Tatsushi. 2017. "Toward a Buddhist Theory of Conflict Transformation: From Simple Actor-Oriented Conflict to Complex Structural Conflict." Peace and Conflict Studies 24 (2): 31.

Arai, Tatsushi. 2019. "Conflict Intervention Training as Strategic Convening: Lessons From Syria.” Journal of Peacebuilding \& Development 14 (3): 288-303. $10.1177 / 1542316619862770$.

Arai, Tatsushi. 2021. "Peace Research from within Peace Practice: Discovering the Untapped Potential of Reflective Practice for Research Innovation." Keynote Address presented at the Peace and Conflict Studies Journal Conference, NOVA Southeastern University, Florida, February 10.

Arai, Tatsushi, Shihoko Goto, and Zheng Wang. 2013. Clash of National Identities: China, Japan, and the East China Sea Territorial Dispute. Washington, DC: Wilson Center.

Argyris, Chris, and Donald Schon. 1974. Theory in Practice: Increasing Professional Effectiveness. San Francisco: Joseey Bass.

Aristotle. 2011. Aristotle's Nicomachean Ethics. Chicago: University of Chicago Press. Arms Almengor, Rochelle. 2018. "Reflective Practice and Mediator Learning: A Current Review." Conflict Resolution Quarterly 36 (1): 21-38. 10.1002/crq.21219.

Avruch, Kevin, and Susan Allen Nan. 2013. "Introduction: The Constraints and Opportunities of Practicing Conflict Resolution from Academic Settings." Negotiation Journal 29 (2): 205-212. 10.1111/nejo.12018.

Boyer, Ernest L. 1996. "The Scholarship of Engagement." Journal of Public Service \& Outreach 1 (1): 11-20.

Bradbury, Hilary. 2016. The SAGE Handbook of Action Research. http:// www.credoreference.com/book/sageuka.

"Bridging the Gap: Carnegie Corporation of New York Awards \$5 Million to Universities for Innovative Programs Linking Academia and Policy.” 2020. Carnegie Corporation of New York. https://www.carnegie.org/news/articles/ bridging-the-gap-carnegie-corporation-of-new-york-awards-5-million-to-universities-for-innovative-programs-linking-academia-and-policy/.

Cho, Jeasik, and Allen Trent. 2006. "Validity in Qualitative Research Revisited." Qualitative Research 6 (3): 319-340. 10.1177/1468794106065006.

Dina Alborova, Susan Allen, and Nino Kalandarishvili, eds. 2016a. Cost of Conflict: Core Dimensions of the Georgian-South Ossetian Context. Fairfax, Virginia: George Mason University and the Alliance for Conflict Transformation.

Dina Alborova, Susan Allen, and Nino Kalandarishvili, eds. 2016b. Cost of Conflict: Untold Stories, Georgian- South Ossetian Conflict in People's Lives. Fairfax, Virginia: George Mason University and the Alliance for Conflict Transformation.

Dugan, Maire A. 1996. "A Nested Theory of Conflict." A Leadership Journal: Women in Leadership- Sharing the Vision 1 (July): 9-20. 
Elder, C 2016. "Participatory Action Research (PAR), A Tool for Transforming Conflict: A Case Study from South Central Somalia.” Life and Peace Institute. http://life-peace.org/wp-content/uploads/2016/07/Somalia_PAR_WEB-1.pdf.

Elliot, Michael, Tamra Peason d'Estree, and Sanda Kaufman. 2003. "Evaluation as a Tool for Reflection." Beyond Intractability Knowledge Base. https://www. beyondintractability.org/essay/evaluation-reflection.

Gamaghelyan, Philip. 2017. Conflict Resolution beyond the International Relations Paradigm: Evolving Designs as a Transformative Practice in Nagorno-Karabakh and Syria. Soviet and Post-Soviet Politics and Society, Vol. 171. Stuttgart: Ibidem-Verlag.

Geertz, Clifford. 1973. The Interpretation of Cultures: Selected Essays. Harper Torchbooks; TB 5043. New York: Basic Books.

Gopin, Marc. 2019. "The Cultivation of Compassionate Reasoning as a New Approach to Conflict Resolution, Genocide Prevention, and Human Rights Training." Lecture presented at the Anthenaeum lecture, Claremont McKenna College, February 27. https://www.cmc.edu/athenaeum/cultivation-of-compassionate-reasoning-as-new-approach-to-conflict-resolution-genocide.

Kelman, Herbert C. 2000. "The Role of the Scholar-Practitioner in International Conflict Resolution." International Studies Perspectives 1 (3): 273. 10.1111/1528-35 77.00027.

Lather, Patti. 1986. "Issues of Validity in Openly Ideological Research: Between a Rock and a Soft Place.” Interchange 17 (4): 63-84. 10.1007/BF01807017.

Lederach, John Paul. 1999. The Journey toward Reconciliation. Scottdale, Pa: Herald Press.

Lehti, Marko. 2019. The Era of Private Peacemakers: A New Dialogic Approach to Mediation. Rethinking Peace and Conflict Studies. Cham, Switzerland: Palgrave Macmillan.

Lewin, Kurt. 1946. "Action Research and Minority Problems." Journal of Social Issues 2 (4): 34 46. 10.1111/j.1540-4560.1946.tb02295.x.

Nan, Susan Allen. 2003. "Formative Evaluation.” Beyond Intractability (blog). 2003. https://www.beyondintractability.org/essay/formative_evaluation.

Nan, Susan Allen. 2010. "The Roles of Conflict Resolution Scholars in GeorgianAbkhaz and Georgian-South-Ossetian Conflict and Conflict Resolution." Cambridge Review of International Affairs 23 (2): 237-258. 10.1080/09557571003745856.

Nan, Susan Allen. 2011a. "Consciousness in Culture-based Conflict and Conflict Resolution." Conflict Resolution Quarterly 28 (3): 239-262. 10.1002/crq.20022.

Nan, Susan Allen, ed. 2011b. Georgian-South Ossetian Conflict: Researching Peace, Georgian Papers. Tbilisi, Georgia: Georgian Foundation for Strategic and International Studies.

Nan, Susan Allen. 2011c. Georgian-South Ossetian Conflict: Researching Peace, South Ossetian Papers. South Ossetia: Center for Information Technology: Intellectual Resources.

Nan, Susan Allen, and Greiff, Jacquie L. 2013. "Basic Human Needs in Practice: The Georgian-South Ossetian Point of View Process." In Conflict Resolution and Human Needs: Linking Theory and Practice, edited by Kevin Avruch and Christopher Mitchell, 202-215. New York: Routledge.

Nan, Susan Allen, Zachariah Cherian Mampilly, and Andrea Bartoli. 2011. Peacemaking: From Practice to Theory. Westport, UNITED STATES: ABC-CLIO, LLC. http://ebookcentral.proquest.com/lib/gmu/detail.action?docID=820300. 


\section{Practice Builds Theory}

Patton, Michael Quinn. 2011. Developmental Evaluation: Applying Complexity Concepts to Enhance Innovation and Use. New York: Guilford Press.

Peirce, Charles S. 2010. Philosophy of Mathematics: Selected Writings. Edited by Matthew Moore. Bloomington: Indiana University Press.

Rice, R Eugene. 2006. "From Athens and Berlin to LA: Faculty Work \& the New Academy." Liberal Education 92 (4): 6-13.

Rothbart, Daniel, 2021. "Conflict Research as Reflective Praxis: Concept Note."

Rothman, Jay. 2007. "Action-Evaluation and Conflict Resolution: In Theory and Practice.” Conflict Resolution Quarterly 15 (March): 119-131. 10.1002/crq.390015 0206.

Rubenstein, Richard. 2020. "Some Thoughts about Conflict Theory: Short Answers to Common Questions." Unpublished Paper.

Toal (Gearóid Ó Tuathail), Gerard, and John O’Loughlin. 2013. "Inside South Ossetia: A Survey of Attitudes in a de Facto State." Post-Soviet Affairs 29 (2): 136-172. 10.1080/1060586X.2013.780417.

Weiss, Thomas G, and Anoulak Kittikhoun. 2011. "Theory vs. Practice: A Symposium.” International Studies Review 13 (1): 1-5. 10.1111/j.1468-2486.201 0.00991.x. 


\section{People Make Peace}

Institutions and governance structures surely influence war and peace, but people are essential drivers of peacemaking. Many individual people make choices that add up to war or peace, and people-centered peacemaking means that people navigate their social, cultural, and political contexts to bring the process to life. Doris Allen (1991) often shared her conviction that, "The power of love is greater than the love of power." When people believe that, they believe they can make a difference. People will take the risks required to help the people around them, if they believe their help will be useful.

Consider the risks taken by those who engaged in the Tajik peacemaking efforts that eventually built a coalition government out of the ruins of the 1992-1997 civil war in Tajikistan. During the civil war, the Tajik government tasked Professor Abdul (whose first name is not included in the published account) to go into the mountains and convince the leader of a military faction to come to negotiations (Lederach 2005). As Abdul later described to John Paul Lederach when they met in 2002, he developed a relationship with the leader during many trips to the mountains and many long talks about Sufism and philosophy. Eventually, Abdul asked the man to come down from the mountains for negotiations. The man asked if Abdul could guarantee his safety. Lederach recalls Abdul's response (Lederach 2005, 18): "I cannot guarantee your safety.... But I can guarantee this. I will go with you, side by side. And, if you die, I will die." Both - the man in the mountains and the mediating professor - were willing to take risks to enter into peacemaking negotiations.

When Tadevosyan (2019) asked peacemakers why they chose to do peacemaking, she found that many who lived in war zones began their peace activities to address immediate humanitarian needs in their own communities. During war, governmental priorities turned to military efforts, and individual residents had to fill immediate humanitarian needs. Some stepped up to fill the gap and developed community groups to address the war's humanitarian catastrophes. After the war, many communities made rebuilding community connections a local priority. While not discounting the role of the most senior political or military leaders as shapers of violence and peace, this chapter focuses on lower-profile individuals who contribute to peacemaking. 
The people-centered peacemaking approach fills a gap left by statecentric, institution-centric, and top-down approaches to peacemaking. These approaches cannot succeed without people who do the hard work in relevant local communities to make peace. In 2009 I wrote about the shift from "coherent" approaches to understanding peace processes to "holistic" approaches (Nan 2009a). I emphasized the shift from a mechanistic adding up of "pieces of peace" (a coherence focused approach in which pieces add up to a larger peace) toward a more holistic approach to a complex dynamic system of interactions of diverse individual agents that together create peace in unexpected ways that cannot be mechanistically predicted. The peoplecentered peacemaking approach emphasizes how individuals shape the overall peace in their regions. These people are not cogs in a machine interchangeable and replacable. Rather, each plays a specific role, based on their human connections with other, humans involved in the process. These connections are highly personal. Relationships matter, as much peacemaking relies on the trust of the specific people involved. Harold Saunders saw how these individual personal relationships matter in his long peacemaking career, which included many years in official diplomacy as a senior United States diplomat. His final book, which reflects on his years in and out of governmental peacemaking, is entitled Politics is about Relationship: A Blueprint for the Citizens' Century (Saunders 2006).

Much of this chapter emphasizes the Georgian-South Ossetian case, providing examples of people who have shaped the relationship through their peacemaking efforts in unofficial dialogues and reflecting on their shared qualities. Core Georgian and South Ossetian partners worked long term in various phases of the process. We agreed to keep individual contributions to the process confidential while those involved were still alive, so those whose engagement I describe below either passed away or gave permission for their stories to appear in this book. Gradually, new people joined and took on lead coordinating roles, too, but rather than tell everyone's stories in detail, this chapter illustrates some of the diversity among the peacemakers involved. It offers glimpses of a process for peace that unfolded over several years and that will be explored in greater detail later, but focuses for now not so much on the processes of peacemaking but on the people who make peace.

There was an intense quiet in the basement meeting room at the hotel in the Fatih district of Istanbul, where the Point of View process was meeting. Merab Iliich had concluded our two-hour discussion of the many possible ways to address problems arising near the ceasefire line and to provide for quick local de-escalation of potentially dangerous situations that could threaten the ceasefire. It was fall 2010 and the Incident Prevention and Response Mechanism (IPRM, normally convened by the Organization for Security and Cooperation in Europe and the European Union Monitoring Mission) had not met for many months, due to objections by the South Ossetian side, who complained that Georgia had placed a "NATO Corner" 
near Ergneti, where the European Union Monitoring Mission would usually place the IPRM meeting tent along the ceasefire line.

Our morning session had focused on how the Georgians and South Ossetians could address pragmatic problems near the ceasefire line and manage any accidental potential escalations, without the IPRM. Everyone agreed there were local problems that needed to be addressed: cows crossed the ceasefire line and needed to get home to their owners; the wolf population was growing, as no one was shooting wolves near the ceasefire line; and both Georgians and South Ossetians explained that there was always the chance that someone would get drunk on their birthday and shoot into the sky and inadvertently re-start the war. This is a small example of the importance of local cultural knowledge: I had no idea, coming from my Washington, D.C. upbringing, that people would shoot into the sky on their birthdays. All the Georgian and South Ossetian participants in the process knew that this was possible, and potentially dangerous.

We had started this meeting by brainstorming about arrangements that could routinely address these kinds of issues. Would a hotline work? A meeting without the IPRM tent, perhaps, in a different place? An online exchange? An individual problem-solver who would shuttle back and forth to address emergent issues? Having made a list of possibilities, we considered the pros and cons of dozens of them.

All the while, we talked around the issue of South Ossetia's refusal to go to the IPRM. The IPRM had worked for years, so why stop it? We took the South Ossetian refusal as a given, and looked at other options and workarounds. Surely, we could devise a process that both sides could use to address local emergent problems.

But, faces fell as the analysis of cons outweighed the pros in each of the options we considered. I said that we would conclude the discussion soon to take a break for lunch. And then, Merab spoke, quietly but decisively: "OK. I'll go home and have some conversations, and I think you will see in two or three weeks the IPRM will meet."

Merab was making a commitment, as an individual, that he would try, personally, to convince the South Ossetian leadership to restart the IPRM. He would go home to South Ossetia and try to convince his colleagues there of his decision. And, we all trusted that Merab stood a really good chance of success.

We trusted Merab because we had come to know him as an individual worthy of that trust - someone who spoke precisely and made commitments carefully. The South Ossetians trusted him to help write the press release issued at the end of each workshop because he was careful to word things clearly, and inoffensively to either side. And he was someone who both Georgians and South Ossetians welcomed as the toast master for the evening meal. He raised toasts that everyone could participate in with a clean conscience: for ancestors, for future generations, for love, and even for homeland, without any political specification $=$ of what "homeland" connoted. (I understood that South 
Ossetians consider South Ossetia their homeland, but Georgians consider Georgia - including South Ossetia - as their homeland, but none of us defined or stated this as we toasted generally for each of our homelands.)

A few weeks later, on 28 October 2010, the Dvani/Ergneti IPRM met for the first time in a year.

The short vignette above highlights how Merab Iliich Chigoev, as an individual, made a tangible difference in restarting the IPRM. He could travel to meet in the unofficial Point of View dialogue with Georgians, consider options, and return home with an idea and the social capital and positionality to pursue that idea. He could not restart the IPRM by himself - but he could and did persuade relevant colleagues of the wisdom of that approach. Chigoev's initiative illustrates the power of individuals who activate their social capital for peacemaking (Nan 2009b).

The power of individuals to take decisive action for peace has been illustrated in numerous other contexts as well. Rugaragu's study of leadership for peace in sub-Saharan Africa describes ethical pragmatism as an effective leadership approach that supports the difficult choices required for peacemaking (Rugaragu 2017). The ethical leaders Rugaragu studies build social capital over time and come to be known as ethical leaders. These individuals who make a difference for peace build on their personal reputation to encourage those around them to take the required risks for peace. In another example, Brigadeir General Roger Mortlock made a controversial decision when he prepared to lead New Zealand's Truce Monitoring Group in neighboring Bougainville. He brought the peacekeeping force in to Bougainville entirely unarmed or, as he put it, armed with guitars. His personal social capital allowed him to move forward with his controversial plan, which ultimately led to a successful mission (Watson 2019).

In the South Caucasus, too, I have seen that individuals derive authority in part from their personal reputation. Their relationships and history matter as they navigate through difficult conversations. There is a sense that these people are known, their families are known, and their reputations precede them. For example, Zurab Lakerbaia has a personal and family reputation that allows him to play a bridging role between Georgian and Abkhaz societies. Lakerbaia is part Abkhaz and part Georgian and comes from a family that commands significant respect in both societies. Starting in 1995, Lakerbaia communicated between the two societies, traveling back and forth across the conflict divide even at times when few people could do so, and assuming the role of Executive Secretary of the Abkhaz-Georgian Bilateral Commission (Francis 2011). Lakerbaia shuttled messages between the leadership in both communities and supported initiatives aimed at building constructive relations. When I met him in 1999, he was working with Abkhaz and Georgian leadership to facilitate a USAID-funded program that brought 30 Georgian and 30 Abkhaz teenagers to George Mason University in the summers of 1999 and 2000 to study conflict resolution. As I traveled to meet separately with the Abkhaz youth in Gagra and the 
Georgian youth in Borjomi before the first summer program, I saw Lakerbaia treated as a respected envoy in both communities. Twenty years later, I saw Lakerbaia in Tbilisi, as he had continued his work to bridge the Georgian and Abkhaz communities.

The South Ossetian-Georgian relationship specifically has not had one but rather several individuals over the last two decades who have taken on a similar bridging role for short periods of time, or on specific issues. In the 1990s, the Khachapuri family acted as a bridge between Georgian and South Ossetian leaders, but they have since left the area. More recently, Lira Kozaeva, a former school principal and now director of the vocational college in South Ossetia, has occasionally played a personal bridging role between South Ossetians and Georgians with a focus on human rights. In 2016 when then State Minister for Reconciliation and Civic Equality Paata Zakareishvili wanted to arrange a simultaneous prisoner release by Georgian, Abkhaz, and South Ossetian authorities, Zurab Lakerbaia helped him work with the Abkaz on arrangements, and Lira Kozaeva helped him work with the South Ossetians.

My practical experience has demonstrated time and again that people make peace. The six peacemakers profiled below have been influential in shaping the Georgian-South Ossetian relationship, and illustrate that individuals outside of senior leadership are part of the peacemaking process. Of course, there are many others who could be profiled here. These six are only examples, but demonstrate some of the diversity of peacemakers. Two (Lira Kozaeva and Paata Zakareishvili) had long served as senior coordinators of the Georgian-South Ossetian civil society peacemaking process. Presenting their peacemaking journey is part of explaining how the Point of View process started. And, time takes a toll on peacemakers, as it does on the rest of us, and living with conflict is especially precarious: the other four people introduced below were actively engaged in the peacemaking process in the past decade, but have passed away. They leave a legacy of pieces of peace in the Georgian-South Ossetian relationship.

\section{Lira Kozaeva}

I first learned of Lira in 1998, when I was in Tskhinval(i) $)^{1}$ interviewing people for my dissertation on the coordination and complementarity of multiple conflict resolution efforts (Nan 1999, 2008a). The Georgian-South Ossetian case was one of the complex peace processes that I examined. One of my interviewees suggested I should meet Lira. At the time, she was not working on conflict resolution so much as human rights. But she was an active civil society member who had founded an NGO and had started a "Sunday school" in South Ossetia. The idea of the Sunday school was to teach informally, outside of the education system. In Lira's case, the school focused on teaching about human rights. Lira was also the head of the main school in Tskhinvali from 1995 to 2002. In 1998, near the end of my research 
time in Tskhinval(i), I went by the school, but it was closed already for the day. Although I did not interview her at that time I remembered the stories I heard about Lira, the South Ossetian woman who was seizing a leadership role and advocating for human rights.

Ten years later, in 2008, Lira and I finally met. The story leading up to our meeting illustrates how peacemakers find each other, develop relationships of trust, and navigate different roles and interests. One of the goals of this book is to share insights about how peacemaking is practiced, and this story shows aspects of peacemaking in the earliest stages. Lira dared to think beyond her home in South Ossetia as she recovered from the August 2008 war. Lira explained to me that in the weeks after the ceasefire, she expressed her shock to a close friend (who shall remain anonymous at Lira's request) that the international community was starting to blame Russia for the war that Lira knew also included substantial aggression by Georgia. Lira wanted to do something about what she considered to be an outrageous lack of understanding. She wanted Westerners to understand the complexity of the war, and not only the Georgian government's perspective on Russian aggression. Lira's friend suggested Lira call a famous Russian (anonymous, once again, at Lira's request) who had global connections, to seek advice. Lira took the phone number and called, but felt flustered when this famous Russian actually answered his phone himself. Surprised that he had taken the call, she immediately forgot his otchestvo (father's name), the usual way to show respect when speaking to a senior person in Russian. In a panic, Lira called him by his family name, using the more distant "Mr." form of address.

Then she nervously plunged into a monologue to explain why she had called. She wanted his advice on how to tell the story of the war in South Ossetia to the west; she wanted her experience to be reflected in the western news; she wanted to right the record so that history would know what had happened; she wanted western journalists to come to South Ossetia and see what had happened there. After her flustered speech, the Russian calmly gave her his email address and asked her to send him her ideas that way. She was so excited, she did not stop to ask him to spell his name and later had to ask an English speaker to guess how he would spell it in English for an email address. Not only did she get the address right, but he called her two days after receiving her email and asked her to come to Moscow to meet three days later with him and Mark Saylor, a public relations specialist with experience throughout the US, who would fly in for the meeting.

Lira's husband Vadik was upset that she was considering a trip to Moscow to chase her dream of sharing the truth of the war. Vadik feared the trip would not amount to anything, but Lira went ahead anyway and found money for a flight and booked herself the cheapest hotel she could find. She headed to a meeting at a hotel near the Ministry of International Affairs. There, she met her Russian contact in the hotel lobby, and went upstairs to meet Mark Saylor and another of his colleagues, who had traveled with him from his public relations firm in the US. The public relations professionals 
suggested a plan to Lira: she would gather a group of women from South Ossetia, some of whom could speak fluent English, and they would travel together to the United States, where they would meet with media and community groups to explain the war. This was a more realistic plan than Lira's original idea of bringing western journalists to South Ossetia. More journalists would meet them as they traveled in the US. Lira agreed, and set about selecting a group of women to travel with her.

Meanwhile, the Saylor Company's Evelyn Iritani set about finding contacts in the US to facilitate the visit, including searching for someone who would invite the group to give a talk, and would issue an invitation sufficient to apply for visas to the US. Evelyn found Paula Garb, an anthropologist who had worked with Abkhaz for many years. She asked Paula to invite the South Ossetians to the US for their talks with media and interested groups, but Paula was concerned that this might negatively affect the Georgian-Abkhaz dialogues she had convened for years, and so she declined to invite the group.

Paula forwarded to me an op-ed in the Christian Science Monitor by Lira (Tskhovrebova 2008). (Tskhovrebova was Lira's husband's last name; Kozaeva was her father's last name, and what she uses now, as a fulfillment of a promise she made to her father on his deathbed.) Lira explained in her piece that Georgia's public relations campaign had presented a false story of the war. Lira offered details of the Georgian attack on sleeping civilians and asked for the US to support Georgia's victims in South Ossetia. In response, I wrote a letter to the editor of the Christian Science Monitor (Nan 2008a) supporting Lira's request for US humanitarian support for South Ossetians as well as Georgians, and urging that we listen also to the voices of South Ossetians. I wrote, taking a people-centered approach, "Ms. Tskhovrebova reminds us the region is first and foremost people's home." Paula shared my letter with Evelyn Iritani at the Saylor Company and suggested Evelyn approach me about a possible invitation for the South Ossetians to visit the US to, as Evelyn put it to me, "Explain the truth about the war."

I explained to Evelyn that I could not issue an invitation focused only on bringing South Ossetians to the US to share their experiences. My focus was always on bridging across conflict divides, so I explained that I could host the South Ossetians in the US to meet in an unofficial three-day peacemaking workshop with Georgians at George Mason University's conflict resolution retreat center outside of Washington, D.C. That idea seemed outrageous just after the war. A peacemaking workshop between Georgians and South Ossetians when the ceasefire was still so fresh and fragile? Here was an example of taking a risk, suggesting an approach that some would call impossible. Would that be pushing things too far too fast? Using the terminology of pushing the envelope, would that push so far as to tear the envelope? Evelyn promised to discuss the possibility with Lira. I waited for several days to hear the results of their discussions. Finally, to my surprise, Evelyn replied that she and the other South Ossetian women would be willing to meet with Georgians for the peacemaking dialogue. 
I took a breath and wondered what I had gotten myself into. Could we really convene a Georgian-South Ossetian peacemaking workshop in six weeks? We would need to recruit Georgians, funding, and a facilitation team. I paused and considered the scale of the work required, but quickly realized that I was not acting alone. There were many people who I was sure would help. I could count on Paula Garb, my long-time mentor with extensive experience with Georgian-Abkhaz peacemaking, and I could count on Lara Olson, who had first introduced me to South Ossetians in 1998 and had worked on Georgian-South Ossetian peacemaking years before the 2008 war. And I was on study leave from the university, which meant that I was not teaching that semester and would be able to set aside writing and focus full time on this. So I took another breath and wrote invitation letters for the South Ossetians to come to the US for a peacemaking dialogue with Georgians, and for additional meetings to speak about the war to US audiences and media.

The letter described "a dialogue with unofficial Georgians eager to rebuild constructive South Ossetian-Georgian communication in the aftermath of the war (Nan 2008b)." I tried to be clear about the multiple purposes of the trip in the invitation:

In collaboration with UC-DC Center, UC-Irvine's Center for Citizen Peacebuilding and the Monterey Institute of International Studies, we have developed a full-time series of speaking engagements and educational and cultural events. Some of these events are also aimed at bringing Georgians and Ossetians together to discuss the future of the Caucasus, while others are aimed specifically at allowing American participants to learn about your perspectives on the recent war and the prospects for peace while you to learn about American perspectives. (Nan 2008b)

Throughout all stages of considering, initiating, and convening the dialogue, I called on colleagues for help. I consulted extensively with Garb and Olson. I reached out to Georgian peacemakers we had worked with years earlier. Paata Zakareishvili and Giorgi Khutsihvili (introduced below) helped recruit other Georgian participants. I wrote invitation letters to each of the Georgian participants so they could secure their visas. I recruited a team to assist with the workshop, including Paula and Lara and Ekaterina Romanova, a doctoral student in conflict resolution who was Russian, and Ethan Finley, a doctoral student who graciously agreed to help with whatever might be needed.

I sought out rapid response funding opportunities, each of which was limited to small amounts. George Mason University's Point of View Fund, Milt Lauenstein, the Planethood Foundation (following Lauenstein's introduction), and USAID in Washington all contributed funds that made the three-day workshop possible. Together, these funds covered travel for the Georgians and out of town facilitators, the hotel for the Georgians and 
the facilitation team, and meals, coffee breaks, and local transportation for everyone. The South Ossetians would cover their own travel and hotel, as they had secured funding for their trip from the famous Russian Lira had contacted who had arranged the public relations tour that they planned to do before the workshop. The facilitators graciously agreed to donate their time.

Lira went to an interview for her visa in Moscow. She had sent the U.S. Embassy in Moscow my letter of invitation, and also carried a copy of the letter with her to the visa interview at the Consulate. She wanted to be prepared to answer detailed questions. But, the consular officer simply asked her the purpose of her trip. At that question, Lira cried. She explained the tragedy of the war as a personal one that separated her family. Lira's mother was Georgian and her father South Ossetian. Through her tears, she managed a brief explanation of the purpose of her trip. After the others were interviewed visas were granted for the full group, and days later they boarded their flight to Washington.

\section{Paata Zakareishvili}

Paata Zakareishvili was one of the first Georgians I invited in October 2008 to participate in a dialogue with Lira and the other South Ossetians. I had first met Paata in 1996 when I traveled to Tbilisi as a graduate student and a Russian-speaking assistant to the Director of the Institute for Conflict Analysis and Resolution (ICAR). We went to Tbilisi and Sukhum(i) to explore a potential Georgian-Abkhaz dialogue. At the time Paata worked in the Georgian Parliament as a staff member for the Committee on Human Rights and National Minorities. I remembered Paata's constructive participation in many Georgian-Abkhaz dialogues convened by Paula Garb in the late 1990s. I knew Paata was passionate about bridging conflict divides. He sought to understand people who had perspectives different than his own, and he was ready to acknowledge mistakes the Georgian leadership had made. When I called him, I jumped directly to my question: would he come to the Georgian-South Ossetian dialogue in six weeks? He agreed immediately.

Paata had a long track record with peacemaking in the South Caucasus in 2008 and it has grown since - he has documented his more recent activity in his 2021 memoir (Zakareishvili 2021). His peace work started when he worked during the 1992-93 Georgian-Abkhaz war to arrange for the return of military and civilian prisoners, missing persons or information about missing persons, and the remains of the deceased. Paata returned the bodies of many deceased soldiers across the front lines to their home communities.

Paata had not always been a bridgebuilder. As he tells it, he grew up a nationalist. The Georgian history he learned cast the Georgians as perpetual victims. He did not consider himself, for example, anti-Armenian, but as pro-Georgian. Then, thanks to the intricacies of the Soviet university admissions systems, Paata faced a choice about his college education: he could 
either go to university in Tbilisi, after a year of waiting, or he could go study in Kazan, the capital of Tartarstan, immediately. He chose Kazan, not knowing what to expect.

At the university in Kazan, Paata encountered students from Cuba, East Germany, Nicaragua, and all over the Soviet Union. He told me that the intercultural university experience showed him the common humanity we share. And, he developed some humility - he realized that there are other people who are good at other things. When he returned to Tbilisi in 1984, he did not fit in well. He had an interest in learning about other cultures, and he knew what it was to live in a foreign context. He no longer blindly promoted Georgians above all others.

As perestroika (the Gobachev-era program of rebuilding the Soviet Union) began in the late 1980s, Paata found himself defending the South Ossetian right to use their own language, drawing the criticism of Georgians around him. But, based on his university experience, Paata was sure that a respect for other languages was appropriate.

After the 1992-93 fighting, Paata was working as a staff member for the Georgian Parliament's Committee on Human Rights and National Minorities when Paula Garb approached him on Abkhaz's recommendation. She had spoken with Abkhaz about a potential Georgian-Abkhaz dialogue, and the Abkhaz had recommended Paata as a Georgian participant in the dialogue. The Abkhaz leadership trusted him, because he had demonstrated integrity during the war when he helped with humanitarian issues such as missing persons, remains of the deceased, and prisoners.

Years later, after yet another war in 2008, I was relieved when Paata agreed to come to the Georgian-South Ossetian dialogue in December of that year. He was experienced. He would know how to support a constructive conversation. At the time, no one, not even Paata, knew that years later he would become the Georgian government's State Minister for Reconciliation.

\section{Giorgi Khutsishvili}

Next, I called Giorgi Khutsishvili. Giorgi was a senior Georgian academic who was a mathematician turned philosopher turned conflict specialist. $\mathrm{He}$ was a leading "conflictologist" in Georgia: a conflict analyst and specialist in conflict resolution theory. I had met with Giorgi several times in 1998 and we had stayed in touch over the years. He spoke English very well. He, too, quickly agreed to participate in the December Georgian-South Ossetian dialogue. He knew Lira, and wanted to see Lira and the group she would bring to the dialogue. At the time, it was almost impossible for Georgians and South Ossetians to meet at home, where the ceasefire line was impermeable. Again, I was relieved to have an experienced Georgian partner joining the dialogue.

Giorgi brought not only significant conflict resolution experience from Georgian-Abkhaz and previous Georgian-South Ossetian initiatives but also 
scholarly study as one of very few scholars in the conflict resolution field in Georgia (Khutsishvili 2018). Giorgi had completed a fellowship at Stanford University's Center for International Security and Arms Control in 1993, supported by the US State Department through the International Research and Exchanges Board (IREX). In 1994, Giorgi became a faculty member in Conflict and Peace Studies in the Department of International Law at Tbilisi State University, and in subsequent years he was a regular commentator on conflict issues in Georgia, served on a conflict assessment team for USAID Caucasus, and engaged in the global conflict resolution field through the Global Partnership for the Prevention of Armed Conflict.

Giorgi volunteered to help collect a group of Georgian participants. Over subsequent weeks I provided him with the names of constructive Georgian colleagues who had proven track records from previous dialogues before the August 2008 war, and Giorgi explored potential new participants, as well. Giorgi became the coordinator of the dialogue planning on the Georgian side. He was my central point of contact for dialogue and travel arrangements. I would call Giorgi to discuss new details as they developed, which he would then share with the other Georgian participants. Giorgi read over and approved the draft agenda for the dialogue and ensured that all Georgian participants were on board with the dialogue plans. I trusted Giorgi to prepare Georgian participants with appropriate background on what to expect, to the extent possible, but I also realized that none of us knew for sure what to expect.

\section{Manana Mebuke}

Lira asked me to consider including her friend Manana in the Georgian group. Manana and Lira had developed a cross-conflict friendship. They had first met when Manana was planning a women's peacebuilding council and sought South Ossetian participants a few years before the 2008 war. Manana and some Georgian women first met Lira when they visited her home in Tskhinval(i). Later, Manana proposed that Lira work with Kvinna, a Swedish foundation that promotes women's rights in conflict areas. Lira and Manana worked together with support from Kvinna and developed a strong working relationship with each other. I had not met Manana when I invited her to join the dialogue but I knew that Lira trusted her to be at the dialogue and that she had led an organization for wives of men who had been disabled or killed during war.

Manana became committed to peace after she saw her husband traumatized by his war experience. Manana spoke about her husband when she described the development of her commitment to peace to me. Her husband had fought in the Georgian-Abkhaz war in 1992-93, and had returned psychologically damaged. He did not recover, and soon died by suicide. After his death, Manana found comfort and support with other women who had lost husbands in the war. Together, they formed a group to support all 
women whose husbands had been disabled or killed during the war. One of their goals was to connect with women across the conflict divides who had also lost husbands. They saw their cross-conflict work as healing for individual participants who could develop personal relationships despite - and because of - their shared experience of loss during the war.

\section{Anna Sanakoeva}

I met Anna Sanakoeva when the South Ossetians arrived with Lira in December 2008, a week or so before the workshop. I arranged homestays for them for two days of rest before the dialogue workshop. They each stayed in different apartments in my building, in my neighbors' guest rooms. Anna was one of the South Ossetians who baked Ossetian pies (Kuchity n.d.) - a white dough with cheese or beet tops in the middle - and shared them with homestay hosts at a group dinner. In order to make the Ossetian pies, she wanted to find the right cheese. My local Giant Food didn't have enough choices, so we went to a Whole Foods grocery, and there she found some cheese she thought would be okay. It was more than okay! Neighbors raved about the Ossetian pies and appreciated the chance to get to know the South Ossetian visitors and a bit of their cuisine.

I also appreciated the opportunity to get to know Anna and the other South Ossetian women in person before the dialogue. I learned that Anna spoke English flawlessly. And I learned in a future dialogue in Istanbul that she also spoke fluent Turkish, when our mini-bus driver was lost and needed directions to find our meeting space. She knew the world of international organizations well: she had worked at the OSCE office in South Ossetia until its office closed in the aftermath of the August 2008 war and she was immediately hired by the office of the International Committee of the Red Cross (ICRC) in South Ossetia. I was confident when I spoke with Anna that she was a future leader in her community. She was poised and confident. And despite her pain, she was ready to talk about the horrors of the August 2008 war.

After a few days of rest, the Georgian-South Ossetian dialogue convened in December 2008 at Point of View. Lira, Paata, Giorgi, Manana, and Anna were among the peacemakers gathered there for the unofficial GeorgianSouth Ossetian discussion in the aftermath of the August 2008 war.

On the evening of December 15, 2008, I drove a white university van, ready to fetch seven passengers, plus luggage, to take them to the Hampton Inn hotel near Point of View. I was quite a sight - a disheveled professor carrying my characteristic backpack and, for that day, also carrying an uncharacteristic red helium balloon that would help my old friends find me. I left the van in short term parking close to the international arrivals hall, and with great anticipation I scurried from the cool and gray day outdoors into the fluorescent-lit airport. The board showed the Georgians' flight from Munich had arrived just after three others. They would be in the immigration line a 
long time, and they'd already been traveling 24 hours from Tbilisi to Munich and now Washington.

I browsed news on my laptop as I waited. And when I did so, an Associated Press headline punched me in the stomach: "Exclusive: Questions of KGB Ties for Activist" (Siegel 2008).

A spokesperson for the Georgian Ministry for Internal Affairs had just denounced South Ossetian Lira Tskhovrebova as a Russian agent. The news reported in Georgia Update portrayed Tkhovrebova's trip to the United States as a disinformation campaign sponsored by Russia. Would the Georgians still meet with Lira and the other South Ossetians? Could they meet with someone their government was calling a KGB agent? Had they just flown across the ocean for nothing?

And then, the stream of international arrivals revealed familiar faces. There was Paata. And Giorgi. And one by one I hugged all seven of them, even Manana, who was new to me. And I asked, "Have you seen the news?" and realized quickly that they hadn't.

Giorgi took my laptop and read the English language news piece. They spoke in Georgian at all once. Giorgi navigated to one Georgian website and then another. They passed the laptop around. I do not speak Georgian and stood by, still holding that red balloon, until they handed back the laptop and we started walking to the exit.

In the van they sat in silence, a tension thickening the air. These were respected thought leaders in Georgian society - middle-aged or older, mostly men, and mostly married with children almost my age. Here I was, driving them toward the conflict resolution retreat center, and to a meeting that might not even happen, in light of their government's accusations, after they had flown across the ocean to be here.

Long ago Paula Garb had taught me a core rule of conflict resolution work: the conflict insiders know best what is possible in their context. Follow their lead. (In contrast, ten years before this meeting, I had tried to insist on taking a break mid-morning at another meeting, because my teachers had explained to me the importance of planning short breaks, but the Georgians and Abkhaz at that meeting didn't want a break to interrupt their fragile conversation in its infancy, and thankfully Paula Garb was there to restrain me, empower them, and allow the transformative conversation to develop without interruption.). With this wisdom in mind, I would trust them to decide if they would be safe meeting with the South Ossetians tomorrow.

After we checked in at the budget hotel I asked Giorgi, "What are you thinking after considering the news of the accusations by the Georgian government against Lira? Can the meeting go on tomorrow?"

Giorgi replied, "Yes, of course we will meet. There is a lot to discuss."

This was true. Four months earlier, as detailed in the Report of the Independent International Fact-Finding Mission on the Conflict in Georgia (known as the Tagliavini Report) the Georgian military fired on Tskhinval(i) in the evening of 7 August 2008 ("Independent International Fact Finding 
Mission on the Conflict in Georgia: Report" 2009). Then-President of Georgia Mikheil Saakashvili may have expected support from the US. But Russia would not let the attack, which had killed Russian citizens, go unanswered. The next day, 8 August, Russian troops entered South Ossetia through the Roki tunnel, repelled the Georgian military, and got as far as Gori. Hundreds of people were killed, and many more injured. Those few days in August 2008 changed the Georgian-South Ossetian relationship fundamentally. Families were separated by the fighting. Russia recognized South Ossetia as an independent country. Contact across the ceasefire line became severely restricted.

Now, four months later, Giorgi was right that there was a lot to discuss. The conversations in the hotel lobby that first morning began with an explanation of the quick work by civil society members back home in Georgia while we in Virginia slept. Prompted by messages from the Georgian dialogue participants before they retired for the evening, hundreds of Georgian civil society members had signed a declaration: "We are all agents, agents for peace." The participants in Virginia woke up to this sign of support for Lira and the other South Ossetians.

The dialogue began already at the hotel as we gathered in the lobby and piled into university vans to drive a few miles to Point of View. Instead of an awkward first conversation of small talk about flights and travel while avoiding substantive discussion, participants instead shared immediately and joyously this supportive news and plunged into a discussion about the conflict context the participants shared. The Georgians believed in Lira as a peacemaker, and with the support of civil society colleagues in Georgia, they put to rest the news reports of "agents."

After three full days of discussion at the retreat's Belmont Bay facility, we concluded that first dialogue with several shared understandings. First, the people gathered at Point of View saw reasons to talk between the communities separated by the ceasefire line. There were urgent humanitarian issues that could not be solved solely on one side of the line or the other. Those living on the Georgian-controlled side of the ceasefire line and those living on the South Ossetian-controlled side needed each other when shared goals required physically working on the other side of the line. For example, the search for missing persons, and the flow of irrigation water that crossed back and forth across the ceasefire line both required physical presence on the "other side." Second, they identified one immediate next step: learning more about humanitarian needs during the difficult post-war winter, so that those needs could better be addressed. ${ }^{2}$

While we met in December, CARE International was already seeking funding on its own to learn more about humanitarian needs, having also noted the dearth of information about how the international community could support people in the post-war context (CARE International 2008). Some of those involved in the Point of View December meeting partnered with CARE International to conduct an assessment of humanitarian needs on both 
sides. Several Georgians and South Ossetians visited villages along the ceasefire line, each working on their own side of the line. A small group met in March 2009 in Yerevan to analyze the resulting data together and prepare a report on constructive humanitarian initiatives for the immediate future.

Finally, the large group, comprised of nine Georgians and nine South Ossetians, many from the December 2008 meeting at George Mason, met for what we called a second Point of View dialogue in May 2009 in Istanbul. One Georgian and one South Ossetian who each worked in their respective governments participated (the Georgian government would call them "de facto authorities"), bringing a track one and a half nature to the process. (As described in Chapter Five, track two refers to unofficial peacemaking processes with unofficial people, track one refers to official peacemaking processes with official (governmental) people, and track one and a half is a hybrid form of peacemaking in which official people may engage in unofficial processes.) Among other agenda items, the group was to consider the outcome of the humanitarian needs assessment conducted in the winter and analyzed in March in Yerevan. At this second Point of View dialogue, the group asked to issue a "press release" that would make transparent the goals of the meeting. This short summary noted shared interests in working to "locate missing persons, assist individuals living in particular regions, and open communication between their societies." 3 Chapter Five will further detail the process, in its various phases, as it developed over a decade.

\section{Merab Chigoev}

Over time, new people joined the dialogue process, including Merab Chigoev, or Merab Iliich as we called him in discussions. (Iliich refers to Chigoev's father's name Ilya, and most participants referred to Chigoev by both his first name and the Russian patronymic form of address using his father's name to indicate their respect for him.) Chigoev joined in the latter half of 2009. To recall, he promised to go home and try to restart the IPRM. Merab was the lead of the South Ossetian delegation to the IPRM. He participated in the Geneva International Discussions for the South Ossetian side. He was a lawyer and spoke precisely and logically.

Merab was also an outstanding toastmaster. On two occasions when we gathered in the evenings for the Old New Year after a day of discussion Merab Iliich served as our "tamada" - the leader of the toasts in a traditional Caucasus feast. For all his patriotism and loyalty to South Ossetia, Merab Iliich kept his toasts nonpolitical at our gatherings. He spoke of common human feelings, respect for ancestors, hopes for children, and love. He acknowledged common cultural traditions shared among Georgians and South Ossetians, even singing a Georgian song that he had translated into Ossetian himself. (This translation is significant when readers recall from Chapter Two the discussion of Georgian and Ossetian languages as being part of entirely separate language groups.) He also acknowledged and 
welcomed to the table those of us from other traditions. He was a gracious host. In contrast to the reputation that had preceded him to the dialogue, it was hard to imagine him playing hardball on specific political issues in official talks. If he was unapproachable at official talks, in unofficial gatherings with us he was warm and personable.

As the peacemaking process continued, we lost some of the core peacemakers. Giorgi Khutsishvili passed away from a sudden heart attack during an academic committee meeting at Tbilisi State University. Manana Mebuke died of a brain tumor after battling the cancer for months. The engineer who was pivotal to the repair of the Zonkari Dam, Konstantin Predein, passed away after his health deteriorated in his 80 's. As he crossed a street in central Tkshinval(i), Merab Chigoev was killed by a drunk driver. Anna Sanakoeva was killed violently as she prepared to go abroad to study in the United Kingdom. Anna had just been awarded a Chevening Scholarship, a prestigious full scholarship to study for a masters degree in the UK. She was found shot in the woods outside Tskhinval(i). A South Ossetian man was later convicted of Anna's murder. As of this writing in spring 2021, no South Ossetian has yet completed a Chevening Scholarship.

As I finalized this book manuscript in July 2021, Dina Alborova passed away from COVID. She was only 49. She was one of the South Ossetian coordinators of the Georgian-South Ossetian peacemaking process these last few years. She had partnered with many peacemakers in many different pieces of the peace process. Two decades ago, she had worked with Roger Fisher and others from Conflict Management Group in a joint process with Norwegian Refugee Council that built significant progress in the GeorgianSouth Ossetian relationship in the 1990s. Since the 2008 war, she had partnered with CARE International, International Alert, Berghof Foundation, and George Mason University, all while also completing her $\mathrm{Ph} . \mathrm{D}$. in Vladikavkaz and teaching political science at the university in Tskhinvali. She was a significant figure in South Ossetian society. The President of South Ossetia spoke at her funeral three days after she died, noting that although he had disagreed with her on some issues (she was for an independent South Ossetia, and the President supported closer ties with Russia), he respected her and mourned her loss. South Ossetian peacemaker Lira Kozaeva also spoke at Dina's funeral, sharing condolences that many international peacemakers had sent. News reports highlighted the significant international reaction to Dina's death.

Between tears in the days after Dina's passing, I read an insight into peacemaking that was embedded in condolences I received from a fellow peacemaker, who wrote: "I am so conscious of the personal dimension of the work we do, so I wish you strength at this sad time." Indeed, peacemaking is personal. The people who make peace develop friendships. Dina was both a dear friend and a close colleague. In the messages shared at her funeral and the global participation in her memorial service, I saw also that many peacemakers felt Dina's loss both personally and professionally. 
There are many other people who are making significant contributions to peacemaking in the Georgian-South Ossetian context in 2021. Nino Kalandarishvili and Dina Alborova both have compelling stories of multiple efforts for their home communities, and perhaps I will share those in future writing. Here, I chose to focus on the earlier phase of the start of the Point of View dialogue process, because that is where I hear so many questions - how do these processes get started? But to the less frequent question, how these processes are sustained over time, sustained work is due to efforts of many people over many years, with some joining the initiative as others leave. Until July 2021, Dina Alborova and Nino Kalandarishvili were working with Margarita Tadevosyan and me on a publication of Georgian and South Ossetian insights about the value of dialogue. Earlier, Caucasian House Executive Director Giorgi Kanashvili was deeply engaged in these efforts, and then later his successor Ivane Abramashvili became actively involved. Sustained intensive work over more than a decade has only been possible with a flexible team that welcomes new members and adapts to transitions. This theme returns in Chapter Seven, Peacemakers Adapt.

\section{Positionality}

This chapter has described some of the primary peacemakers in the Georgian-South Ossetian context, the people who are living this full time as the conflict shapes their home communities and daily lives. As for my own positionality, and without detracting from these peacemakers who work in and between their home communities, I will tell you a bit about how I came to my own decades-long focus on peacemaking in this region.

I was first introduced to peace work as a child, as my grandmother shared with me her work as a scholar-practitioner and peace psychologist. Doris Twitchell Allen founded Children's International Summer Villages. Her applied work to build inter-cultural understanding contributed to both inter-cultural understanding and also to theory-building on peace promotion. As a teenager, I carried her books and flipchart to workshops she facilitated on psychodrama. I saw firsthand the power of theory-informed practice, and practice-informed theory. I also saw that people can make a difference for peace.

Indirectly, I came to Georgia by way of Maine, where as a teenager I attended an August session at Alford Lake Camp, during which we welcomed Soviet teens in the aftermath of the Chernobyl accident of April 1986. A year earlier, Samantha Smith, an American teen who wrote to the then Soviet leader Yuri Andropov to advocate progress toward avoiding nuclear war, had died in a plane crash near her home in Maine. Her mother, Jane Smith, and some of Samantha's classmates together traveled in July 1986 to tour the Soviet Union as part of the Samantha Smith Foundation's efforts to further Samantha's goals of intercultural understanding and peacebuilding (Smith, n.d.). Jane Smith helped arrange for some of the Soviet teen 
refugees from Chernobyl to travel to Alford Lake Camp. The Soviet teens and their families had been evacuated from the immediate Chernobyl area, and these teens were sent for a few weeks to the United States to, as they put it, "rest."

We swam in the lake, played soccer, and shared meals and a campfire. But, we couldn't talk with each other very much. There were just a few translators and a large group of teens. So, I decided to learn Russian. I reasoned at the time that language study would be my contribution to intercultural communication with the Soviet Union.

Ten years later, having learned Russian in college, and having led five summers of teens traveling first to the Soviet Union and then, after the Soviet Union dissolved, to Russia, Estonia, and Lithuania, I was a doctoral student at what was then ICAR at George Mason University in Fairfax, Virginia, the predecessor to today's Jimmy and Rosalynn Carter School for Peace and Conflict Resolution, where I currently teach. George Mason University was the first in the world to offer a Ph.D. in Conflict Analysis and Resolution, and it was an exciting, pioneering place to study in the 1990s.

In 1996 two Georgians from Tbilisi studied conflict resolution at George Mason University, and carried a request from the then-president of Georgia, Eduard Shevardnadze. Shevardnadze asked if we at ICAR would try to do something to help with the Georgian-Abkhaz conflict. The ICAR director at the time, Dr. Kevin Clements, looked around for someone at ICAR to travel with him to Tbilisi and Sukhum(i) ${ }^{4}$ to assess possibilities for a conflict resolution process. He looked for someone who spoke Russian, but who was neither Georgian nor Abkhaz. Having learned Russian I was in the right place at the right time.

In December 1996, Dr. Clements and I traveled to Tbilisi and Sukhum(i). It was cold, and electricity was not reliable. By midday it was colder inside some of the thick-walled stone buildings than it was outside, as the sun had warmed the outside air. As we met with people on both sides, I was inspired by people's extraordinary efforts to rebuild after the war. I saw that in Tbilisi, when I met Paata Zakareishvili and learned about his intermediary efforts to return corpses to the other side during the fighting and, conversely, to bring home the bodies of Georgian soldiers who had died behind the Abkhaz front line. He was passionate about the rights of families on all sides to bury their lost relatives, which helped families find some measure of personal peace even in the midst of war. And I saw passionate work to improve their home community as Abkhaz then-president Ardzinba told us about his commitments to ensure the Abkhaz culture and language would survive.

As we sat about planning a Georgian-Abkhaz dialogue after that trip, I tried to reach out to others working in the region to appropriately coordinate our work and ensure complementary efforts. It was difficult, as there was no central list of people working in peacemaking in the region. People kept their work confidential, as they did not want to risk criticism that they were daring to engage with people from "the other side." We 
reached out to the few people we could identify, and from them found a few more conveners of peacemaking efforts. We began to coordinate, trying at least not to do any harm with our scattered efforts. And, I found my dissertation topic. I set out to understand "coordination and complementarity in the conflict resolution processes addressing the conflicts over Abkhazia, South Ossetia, and Transdniestria."

I spent much of 1998 abroad, interviewing Abkhaz, Georgians, South Ossetians, Moldovans, and Transdniestrians about the conflict resolution processes involving their communities. Others working toward peace became friends. Once, four of us got stuck in Sochi due to a mishap at the airport after a Georgian-Abkhaz meeting, and so we waited for three days for the next flight to Tbilisi. (The first day we spent running around looking for ways to get to Tbilisi sooner, then the next two days we simply relaxed, knowing that we had done all we could.) Another time I showed up at dusk at a Tskhinval(i) bed and breakfast - the only overnight accommodations for rent in the city - and the hostess told me that she'd given my room to "the Ambassador," who had arrived unexpectedly. With my reservation suddenly canceled, I walked to a friend's home to ask her advice as I sought a place to stay in a city with no operating hotels. She and her mother did not hesitate to open their door and invite me into their home and treat me as an honored guest. In one moment I had gone from homeless in a dark city to warm in a cozy home.

While I worked on my doctoral coursework and dissertation, Paula Garb invited me to assist her in the Georgian-Abkhaz dialogues she was convening. I traveled to these dialogues, serving the role of the action evaluator (Rothman 2007). An action evaluator facilitates processes of regular reflection on the goals of peacemaking initiatives, engaging the participants, facilitators and donors supporting peacemaking work in refining their goals, specific plans, and motivations, allowing the initiative to develop over time. Then, my own circumstances shifted: I had a son around this time and at that point, I stopped traveling for many years. Twenty years ago, meetings of consequence were held in person. Internet connections to many cities in the region were unreliable. So, I no longer participated in the Georgian-Abkhaz discussions but I stayed in touch with a few people there through occasional emails.

Then, in the summer of 2008, people who knew me from the 1990s began reaching out to me. As tensions rose, they asked me to re-engage. Surely, they argued in July, my children were old enough - by then aged four and seven - for me to travel again? I agreed to re-engage in the fall. But, the war happened in August. My re-engagement became instead an effort to re-build after a war, rather than an effort to prevent a war.

I am often asked whose side I am on in this conflict, since I've been involved for so many years in the region. I am not on any political side - not the side of territorial integrity nor of self-determination. I am impartial on those substantive questions. But, I am partial about process. I want to support processes that do not involve a return to war and are inclusive of the 
concerns of all of my friends and their broader communities. I want to support respectful engagement that acknowledges the concerns on all sides, the grievances that so many carry, and the traumas that so many have experienced. I want to support the search for a way forward that will provide everyone with freedom of movement, education in their native language, warm homes, and the possibility for fulfilling futures for their children.

In addition to the challenges of being a scholar-practitioner and a pracademic (practitioner-academic) in a university described earlier (Avruch and Nan 2013), there are also opportunities that come with the university affiliation, and that open possibilities for peacemaking practice. For example, the books published with Georgian and South Ossetians peacemakers together (Alborova, Allen, and Kalandarishvili 2016a; 2016b; Nan 2011b; 2011a) were possible because the authors were willing to have their work appear together, despite the taboo in their societies of engaging with "the other," and because they felt that my university position gave them some cover, so that if they were questioned about why they published an article alongside an "enemy," they could reply that their engagement was with an impartial university professor. And, I find my decades of studying conflict resolution are also an advantage. Because I've learned about many peacemaking processes over time, I have developed a robust range of approaches to consider as I engage in peacemaking practice.

Being transparent about who I am, and how and why I came to peacemaking has been essential to my peacemaking practice. I learned radical transparency from Joseph Camplisson, a peacemaker in Northern Ireland who engaged me as a facilitator in a series of Moldovan-Transdniestrian workshops he convened. At one of these workshops - I believe the first one in which I participated in 1997 - we met the first day in Belfast in a formal government building with a grand hall, professional simultaneous interpretation equipment, and an adjacent area for coffee breaks that was almost as grand. The senior Moldovan and Transdniestrian "Expert Group" members who had been designated by their presidents to participate in the workshop were lingering over the delicious coffee beyond our allotted break time. I asked Camplisson if he would like me to circulate among the crowd, inviting people back into the main hall. He smiled and said, no, he would take care of it. And without another word he burst into song with a booming voice, singing an Irish ballad at the top of his lungs. Everyone turned, stunned, and quickly complied when, having gained everyone's attention, he invited us back to the formal session. As the session began, he shared with us his love of music, and that particular love song. It was a personal sharing, part of building a relationship that went beyond the confidence building measures we were considering in the security zone. And, somehow, the substantive discussions between Moldovans and Transdniestrians became more personable after Camplisson's openness.

That was a practical impact of bringing individuality into the official room. Likewise I believe that sharing some of my story here helps readers 
contextualize the insights presented, with awareness of my positionality in hand. The theory I present can only be understood in the context of the place from which it is developed and interpreted.

It is people who build peace. We all come to peace with our own positionalities, psychologies, social networks, political power, narratives, and live within our respective institutional, community, and national and international structures. Each of us works from a slightly (or radically) different platform, each with different strengths and limitations based on that platform.

With all this uniqueness and contextual idiosyncrasy we might question what peacemaking practices hold in common across contexts. One common element is the focus on process. Peacemakers seek to use peaceful methods, and we see that the means and ends are intertwined. Gandhi wrote (p. 63): "The means may be likened to a seed, the end to a tree, and there is just the same inviolable connection between the means and the end as there is between the seed and the tree" (Gandhi 1938). The next chapter focuses on these means, the processes of peacemaking, the seeds that grow into peace.

\section{Notes}

1 As explained in Chapter 1, here and throughout the book I often use a combination of two terms for the same place to show my respect for both terms. In this case, Tskhinvali is the name Georgians use for the city, and Tskhinval is the name South Ossetians use. I have tried to reflect both by showing the " $i$ " in parentheses.

2 The short description of this first meeting that was later presented on the Point of View dialogue website read: "In December 2008, George Mason University hosted a group of Georgian and South Ossetian peacebuilders at Point of View, the university's conflict resolution retreat house in Mason Neck, Virginia. The meeting sparked a series of discussions that have enriched participants' understandings of the possibilities for confidence building in the aftermath of the August 2008 war. The initial question of this meeting - Is there any reason for us to talk with one another? - sparked a recognition of shared problems and dreams, as well as a willingness to continue meeting and working together toward shared goals." http:// pointofviewdialogue.com/en/index.php/aboutus

3 The full press release from the May-June 2009 meeting reads: "George Mason University's Institute for Conflict Analysis and Resolution hosted South Ossetian and Georgian civil society-based peacebuilders from May 31-June 3 at a workshop in Istanbul. These discussions built on a December 2008 workshop at Point of View, the university's conflict resolution retreat facility at Mason Neck, Va. Susan Allen Nan, assistant professor of conflict analysis and resolution at George Mason University planned the session and facilitated with Dr. Paula Garb, Lara Olson, Kate Romanova, and Georgian and South Ossetian partners. The Point of View process is the only continuing series of track two or citizen diplomacy initiatives meeting regularly since the August war disrupted Georgian-South Ossetian relations.

The 18 individuals in this track two meeting participated in their own personal capacity. During the meeting, they discussed the current situation, the range of related peacebuilding initiatives, as well as plans for developing the Point of View process in the future. 
These unofficial discussions generated creative ideas for improving GeorgianSouth Ossetian relations."The participants persevered through some difficult conversations and found some areas of agreement on the needs to locate missing persons, assist individuals living in particular regions, and open communication between their societies," said Nan. "I am grateful for the sincerity of the participants, and for Open Society Georgia Foundation funding to the International Center for Conflict and Negotiation in Tbilisi for the Georgian participation in the dialogue, and the GMU Foundation's Point of View Fund supporting South Ossetian and general workshop expenses."

Mason and ICAR have been involved in several confidential and nonconfidential citizen diplomacy initiatives over ICAR's 26-year history including talks surrounding conflicts in the Horn of Africa, Middle East, Eastern Europe and the former Soviet Union."

4 Georgians refer to the city as Sukhumi and Abkhaz refer to it as Sukum. I place the "I" in parentheses to indicate the controversial nature of making a name choice and to avoid choosing one spelling over the other in my writing. In speaking, I sometimes use the city name as indicated by the individual I am speaking with, or in group settings with multiple perspectives represented I might mumble to obscure the ending of the city name or say both names. I learned the approach of using both names when I visited "Derry-Londonderry" in Northern Ireland.

\section{Works Cited}

Alborova, Dina, Susan Allen, and Nino Kalandarishvili, eds. 2016a. Cost of Conflict: Core Dimensions of the Georgian-South Ossetian Context. Fairfax, Virginia: George Mason University and the Alliance for Conflict Transformation.

Alborova, Dina, Susan Allen, and Nino Kalandarishvili, eds. 2016b. Cost of Conflict: Untold Stories, Georgian-South Ossetian Conflict in People's Lives. Fairfax, Virginia: George Mason University and the Alliance for Conflict Transformation.

Allen, Doris Twitchell. "The Power of Love Is Greater than the Love of Power." Poster presented at the Children's International Summer Villages, Tokyo, Japan, 1991.

Avruch, Kevin, and Susan Allen Nan. 2013. "Introduction: The Constraints and Opportunities of Practicing Conflict Resolution from Academic Settings." Negotiation Journal 29 (2): 205-12. https://doi.org/10.1111/nejo.12018.

CARE International. 2008. South Ossetia: Assessment of Humanitarian Situation in the Aftermath of August 2008 Fighting. CARE International.

Francis, Céline. 2011. Conflict Resolution and Status: The Case of Georgia and Abkhazia (1989-2008). Brussels, Belgium: Asp/Vubpress/Upa.

Gandhi, M.K. 1938. Hind Swaraj or Indian Home Rule. Ahmedabad, India: Navajivan Publishing House, 96. https://www.mkgandhi.org/ebks/hind_swaraj.pdf.

"Independent International Fact Finding Mission on the Conflict in Georgia: Report." 2009. Brussels, Belgium: IIFFMCG. https://www.echr.coe.int/Documents/HUDOC_ 38263_08_Annexes_ENG.pdf.

Khutsishvili, George. 2018. How to Resolve Conflicts, edited by Nina TsikhistaviKhutsishvili. Tbilisi, Georgia: ICCN.

Kuchity, Ruslan. n.d. "Ossetian Traditional Pies." Ossetians. Accessed April 23, 2021. http://ossetians.com/eng/news.php?newsid=410. 
Lederach, John Paul. 2005. The Moral Imagination: The Art and Soul of Building Peace. New York: Oxford University Press, Incorporated. https://doi.org/10.1093/ 0195174542.001 .0001$.

Nan, Susan Allen. 1999. "Complementarity and Coordination of Multiple Conflict Resolution Efforts in the Conflicts over Abkhazia, South Ossetia, and Transdniestria." Doctoral dissertation. George Mason University, Fairfax, Virginia. Nan, Susan Allen. "U.S. Should Send Aid to Both South Ossetia and Georgia." Christian Science Monitor, October 9, 2008a, sec. Opinion.

Nan, Susan Allen. "Invitation to Lira Kozaeva," Private correspondence. October 27, 2008b.

Nan, Susan Allen. 2009a. "Shifting from Coherent toward Holistic Peace Processes." In Handbook of Conflict Analysis and Resolution, 383-95. New York: Routledge. Nan, Susan Allen. 2009b. "Social Capital in Exclusive and Inclusive Networks: Satisfying Human Needs through Conflict and Conflict Resolution." In Social Capital and Peacebuilding: Creating and Resolving Conflict with Trust and Social Networks. Routledge Studies in Peace and Conflict Resolution. New York: Routledge.

Nan, Susan Allen, ed. 2011a. Georgian-South Ossetian Conflict: Researching Peace, Georgian Papers. Tbilisi, Georgia: Georgian Foundation for Strategic and International Studies.

Nan, Susan Allen, ed. 2011b. Georgian-South Ossetian Conflict: Researching Peace, South Ossetian Papers. South Ossetia: Center for Information Technology: Intellectual Resources.

Rothman, Jay. 2007. "Action-Evaluation and Conflict Resolution: In Theory and Practice." Conflict Resolution Quarterly 15 (March): 119-31. https://doi.org/10.1 002/crq.3900150206.

Rugaragu, Innocent B. 2017. Leadership for Peace and Reconciliation in Post-Violent Sub-Saharan African Countries: Ethical Pragmatism. ProQuest Dissertations Publishing. https://search.proquest.com/docview/1990116549?pq-origsite=primo.

Saunders, H. 2006. Politics Is about Relationship: A Blueprint for the Citizens' Century. New York, United States: Palgrave Macmillan US. http://ebookcentral.proquest. com/lib/gmu/detail.action?docID=308041.

Siegel, Matt. 2008. Exclusive: Questions of KGB Ties for Activist. Associated Press, December 15.

Smith, Jane. n.d. "Samantha Smith Memorial Foundation." website. https:// www.samanthasmith.info/index.php/foundation.

Tadevosyan, Margarita. 2019. Multidimensional Roles of Local Non-Governmental Organizations in Creating Reconciliation Spaces in the South Caucasus. Doctoral dissertation. George Mason University, Fairfax, Virginia. ProQuest Dissertations Publishing. https://search.proquest.com/docview/2312594675?pq-origsite=primo.

Tskhovrebova, Lira. "I Survived the Georgian War. Here's What I Saw." Christian Science Monitor, October 8, 2008, sec. Opinion.

Watson, Will. 2019. Soldiers without Guns. Documentary Film. TMI Pictures. https://soldierswithoutguns.com/.

Zakareishvili, Paata. 2021. Vision: Conflicts in Georgia 2012-2016. Tbilisi: FriedrichEbert-Stiftung. 


\section{Process Shapes People-Centered Peacemaking}

Peacemakers know that they focus more intensely on process than many other professions. We think about the shape of a table, the way a dialogue agenda flows, the order of speakers at meetings, and ways that a conversation's insights can spread throughout communities and influence official peace agreements. I remember when a peacemaking practitioner arrived at the institution where I then worked to interview for a senior position. Given a few minutes before meeting the group of interviewers, this practitioner rearranged the furniture from rows of chairs facing a podium to create a circle that could support a community conversation. The other finalists were more scholars than practitioners, and when they visited for the same interview process they did not rearrange the furniture, left the podium and rows of chairs in place, and that seating arrangement fostered more of a question-and-answer dynamic in a room arranged for a lecture-style presentation. The practitioner with the community conversation process and circular chair arrangement got the job. That brief interaction further reinforced my observation that peacemakers focus on process.

In real estate, it's said that only three things matter: location, location, and location. When asked, I explain that this book emphasizes the only three things that matter in peacemaking: people, people, and people. This chapter examines what peacemakers often think matters the most: process, process, and process - and, of course, processes are created by people. Processes also exist in the context of structural factors such as power dynamics, too. But, for this chapter, let us focus on process.

The conflict resolution field has long focused on peace processes as part of its theory-building. Analysts of peace processes distinguish between different "tracks" of engagement (Diamond 1991). Track One diplomacy refers to official diplomacy by leaders of a state or another group (Montville 1987; 1991). These are people with official standing who engage in official discussions. In the Georgian-South Ossetian context, Track One diplomacy takes place in Geneva, at the Geneva International Discussions (GID), or in a tent along the ceasefire line in Ergneti, through the Incident Prevention Response Mechanism (IPRM). Track Two diplomacy (Montville 1987; Jones 2015) refers to people without official standing who engage in

DOI: $10.4324 / 9781003189008-5$ 
unofficial processes. Sometimes, as we saw in the previous chapter, people engaged in unofficial peacemaking are also government officials who in their personal capacity explore possibilities across the conflict divide. As a student of conflict resolution, I noticed that these dialogues fit neither into the Track One definition nor the Track Two definition, so I designated them Track One-and-a-Half diplomacy (Nan 1999; 2004; 2005). The term has stuck, and is often used to refer to processes where officials engage in unofficial discussions (Jones 2015).

Some of our knowledge about peacemaking processes comes from studies of and stories shared by peacemakers, and rarely from direct observation of peacemakers, because so much peacemaking work must remain confidential. For example, Deborah Kolb worked with colleagues who each presented, analyzed, and compiled stories from mediators in many different contexts, focusing throughout on the process of mediation (Kolb 1994). Other knowledge comes from participant observation, often by members of the peacemaking team. For example, Harold Saunders has written about many of his peacemaking experiences, ranging from the Camp David accords to the inter-Tajik dialogues in 1993-2000 to work on the US-Russian relationship (Saunders 1982; 2003; Saunders 2006). Some of the field's knowledge of processes has been passed along through mentorship and training workshops. For example, Mohammed Abu-Nimer, Eileen Babbitt, Tamra Pearson d'Estree, Ronald Fisher, Christopher Mitchell, and colleagues and I worked together for many years to host Problem Solving Workshop trainings (Fisher 2020) that convened students from their respective universities to do interactive exercises on design and facilitation skills for problem-solving workshops. And, of course, much peacemaking process knowledge is built from experience. This chapter weaves all of these ways of knowing to share insights about process in peacemaking, as drawn from multiple contexts, including Appalachian environmental activists, the US-Russian dialogue, and Estonia.

A prominent characteristic of successful people-centered peacemaking is an emphasis on individual agency. Process choices are based on our understanding of what works in peacemaking processes; in other words, we make our process choices based on our theories of change. Our understanding of people, their contexts, and their possibilities shapes our understanding of what processes will support constructive change.

Elicitive peacemaking approaches emphasize individual agency to make choices that support peace. The people-centered peacemaking approach is based on an understanding that most individuals can assess their own context, their positionality, and their specific opportunities to contribute to peace. With this understanding, the elicitive peacemaker works to provide a supportive environment conducive to people in their particular conflict context and engages to help them identify their own paths forward. Elicitive peacemakers work by drawing out ideas, holding them up for examination, and providing reflective space for participants to consider their options. In 
this understanding, most of peacemaking is listening, and a small part is reflecting back to people in the conflict context what the peacemakers have heard.

In this approach to peacemaking, process decisions are not about control. Peacemakers let go of any illusion of control. Rather, peacemaking is about inviting. Process decisions are about how to invite participation in peacemaking. Recall the story in Chapter 4 of Joseph Camplisson, who, literally, invited Moldovan and Transdniestrian officials from the "Expert Groups" back into the meeting room in Belfast by bursting into a robust, beautiful Irish song. Joe was issuing a personal invitation to return to the meeting room that was startling in its disarming spontaneity and also its volume. His process choice there was to cut through the formality and call people back to a real conversation between real people. He showed himself as a full person - not only a conflict specialist but also a musician. I have since met another conflict resolution professional who was also a musician; she also sang at times to share something in the peacemaking processes.

People-centered peacemaking also involves processes that we can conceptualize in a nested model, drawing on the theory of conflict presented by Moire Dugan (Dugan 1996). Dugan envisioned conflict analysis in layers: issue-specific, relational, two layers of structural: the sub-system and the system, explained below. These layers of analysis helped Dugan make sense of a physical fight that had broken out at a school in Virginia between several white teenage boys wearing jackets with confederate flags and several black teenage boys. Dugan found that the case involved more than the confederate flag issue (the issue-specific layer) and the individual relationships (the relational layer) between these teenagers. It also involved the structural subsystem of the school (in other words, the ways racist dynamics shaped the classrooms and student and staff experiences in that specific school) and the broader "system" of the community and nation. In the case Dugan explains, the racism embedded in the community and nation shaped the school, relationships, and the issues in conflict. Dugan clarifies that these layers of conflict are always nested (and interrelated), as outer layers always manifest some of the inner layers of conflict (Dugan 1996, 16).

Here, with Dugan's work in mind, I theorize the peacemaking process with a nested model. Rather than stop with the issue-specific, relational, and structural aspects of conflict, the nested model of peacemaking (see Figure 5.1) draws in ever larger groups of people involved, and considers how peacemaking engages all of these groups of people. (After all, this is a people-centered approach to peacemaking.) People are not isolated, but we live inextricably in connection with others, in a network society (Allen Nan 2008; Nan 2009). In Figure 5.1 we see the connections in the network society. The outer layers of the process nest show the largest collection of people involved, at the international level, and as we move progressively toward the center, each layer involves fewer and fewer people. 


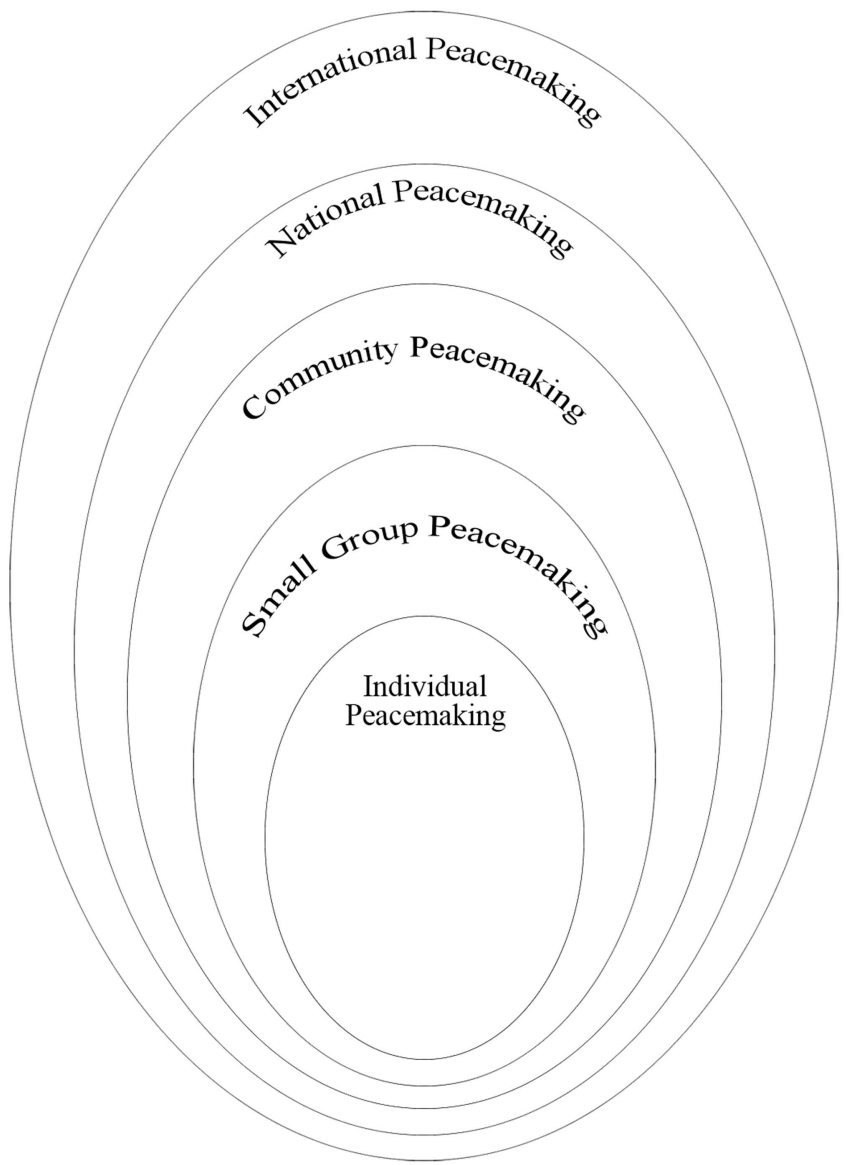

Figure 5.1 Nested Model of Peacemaking.

The most visible processes from afar are most likely the international peacemaking processes. Some of these processes are reported in news items when peace talks are covered by the media; for example, when Somalia and Kenya restore diplomatic relations (Dahir 2021) and France and the U.K. prepare to discuss fishing rights during the post-Brexit era the media labels these talks "peace talks" (Wright and Waterfield 2021). In this writing, these two peace talks are just two of the scores of stories today (May 7, 2021) in the Peace Talks Digest, which collects news about peace talks from many online English-language news sources daily (Carl 2021). Other international processes take place behind closed doors, generally out of reach of the media, and are described only later when historians make sense of the recent past; for example, many have studied the Cuban Missile Crisis (Medland 1990). National processes may also have both publicly visible and covered 
processes (for example, some discussions to end civil wars are covered in the media) and parallel confidential processes that are aspects of conflict resolution processes, too. Zooming in more closely, we see community-level processes. When one region of a country is the focus of a civil war, that region takes on special significance in the peacemaking processes.

The interaction of these layers makes it clear that peacemaking is a multidisciplinary endeavor. Political science analyses tend to emphasize the outer layers, in which institutions and political leaders represent larger groups of people. Political psychology, social psychology, group dynamics, and psychology apply to the inner layers of the nested model, which focus on smaller groups and individuals. And, as the following examples of peoplecentered peacemaking illustrate, these layers in the nested model affect each other, especially through networks that transect multiple layers. Each layer exists amidst the others. Understanding peacemaking processes requires understanding all of these layers.

\section{Multi-Layered Peacemaking: An Example of Appalachian Environmental Activists}

The experiences of environmental activists in Appalachia illustrate nicely a nested, or multi-layered, approach to peacemaking. Over years of working on related issues, these activists had developed conflicts and tensions. There were specific issues, such as an activist campaign that some of the group had not participated in, and the leaders of that campaign felt let down. There were relationship tensions between some of the activists, who felt disrespected. And, there were overall differences in preferred strategies within the movement. These activists wanted to build more constructive relationships, so in 2013 George Mason University professor Arthur Romano and I co-facilitated a workshop for environmental activists, with the goal of enhancing the collective impact of disparate environmental activities by building community where fissures had developed (Romano, Linnemeier, and Allen 2021). As Dugan predicted (Dugan 1996), there were structural and systemic aspects, relational aspects, and issue-specific aspects to the conflicts within the environmental movement. Structural issues included patriarchal structures that created fissures in the movement as some women environmentalists were reluctant to engage with one of the men in the environmental movement. Other structural issues were the extractive industries that exploited the Appalachian people and land, and mobilized the environmental movement to protect the region. Local environmental activists also grouped in the extractive industries category the large environmental groups that they referred to as "Big Green." These larger Big Green groups treated local activists as "Appalachian hillbillies," and trotted them to Washington, DC on speaking tours to help raise funds for their own groups that would work on Appalachian issues at the national level. Relational issues included a history of missed opportunities to support each other's 
work, and a history of marginalizing women's work in the environmental movement. There were specific issues of misogynist statements by one of the male activists, and years of tensions between him and many of the other activists. As we describe in our article on this work (Romano, Linnemeier, and Allen 2021), a shocking misogynist statement interrupted the workshop, which called attention to gender relations in the environmental movement in general, and with this individual in particular.

At the individual level, and as part of the peacemaking process, I met separately with the individual who made the misogynist statement and worked to raise his awareness of the statement's impact. At the group level, Arthur and I worked with the two dozen or so environmental activists to clarify norms for interactions that would support coordination and collaboration, which would in turn increase the impact of their collective efforts. Arthur and I also encouraged activists to focus on the strengths that diversity brings to the environmental movement, and to consider their next steps as a movement after the workshop would conclude. As activists built and strengthened their relationships with each other at the workshop, they strategized ways that they could have more impact together in the coming months, and considered whether it would be possible to work constructively with "Big Green" environmentalists outside of the region without falling into their familiar extractive traps. They planned their next steps.

\section{Shifts in Interiority in Peacemaking}

Peacemaking has impacts on individuals and on relationships among and between individuals. These impacts include shifts in consciousness and the development of respectful, understanding, and trusting relationships.

Elsewhere (Nan 2011), I have highlighted three ways that peacemaking processes support shifts in the interior processes for individuals:

Increasing awareness leads to greater freedom to act constructively in conflict and conflict resolution... A transitional space allows shifts in consciousness supportive of constructive engagement in conflict and conflict resolution... [and] Embodied engagement can support individual shifts. (Nan 2011, 241)

To encourage these shifts in consciousness, peacemaking processes seek to increase awareness, create transitional spaces, and support embodied engagement. Increasing awareness, for instance, can come from hearing perspectives from others in their own words, different than yours, and hearing reflections of how others see you, or having opportunities to ask others how they see things, to learn their viewpoints directly. A transitional space can be created by meeting at a site removed from the usual hectic daily activities, meeting in nature, or going to a retreat center. Space for walking, such as the famous "walk in the woods" that Gorbachev and Reagan took by Lake 
Geneva (Meisler 1988), eating together and breaking bread, and even simply coffee breaks provide opportunities for embodied engagement in which proprioception (awareness of the position and movement of the body) complements cognitive and emotional connection with others. Relaxation in these transitional spaces can refresh the body, mind, and spirit and bring fresh perspectives to peacemaking.

In 2005, I facilitated a particularly tense discussion with Georgian and Abkhaz journalists that demonstrates embodied engagement as a powerful tool of peacemaking. The group had been invited to Washington, D.C. by colleagues who worked on professional development for journalists. Organizers of that trip asked me to hold a two-day workshop with the visitors to complement their main program with US journalists.

These ten individuals were all meeting for the first time since the 1990s war with people from the other side. I felt the tensions from that war and its aftermath embodied in each of us in that room. My shoulders were tense. I was trying to facilitate a discussion about the goals of our meeting, and I thought we were all too tense to reasonably discuss goals. The coffee break was still an hour away. So, I took a deep breath and invited everyone to stand up, pushing their chairs back from the formal table where we sat. I led us in a standing meditation, feeling our feet on the floor, scanning our bodies by moving our awareness gradually up from our feet to notice in turn each part of our body. Then, I turned toward noticing our breathing. And, finally, to noticing others in this room. I asked everyone to notice how it felt to be in this room together. And then, I thanked them for participating and we turned once again to the goals at hand. The tension had melted. The conversation turned constructive. Later in the evening, I reflected that these changes in the conversation were connected to a shift, from the initial trepidation and tension we had all experienced to an awareness of our multifaceted feelings, including our hope that we could build understanding.

\section{Processes of Individual and Small Group Changes in US-Russian Dialogue}

Harold Saunders highlights the development of personal relationships in peacemaking practice (Saunders 2006; Saunders 2003). I saw this emphasis directly when Saunders invited me for several years to collaborate with him on the Dartmouth Dialogue on US- Russian Relations he co-convened with Dr. Vitaly Naumkin, Director of the Institute of Oriental Studies of the Russian Academy of Sciences. These dialogues typically alternated between meeting in Russia and the US. Many of the dialogues took place not far from Moscow or Washington, but on the occasion of one dialogue Naumkin invited us to meet in his hometown of Ekaterinburg. The dialogues would typically involve some sort of cultural experience, and in this case we went together on a tour of Ekaterinburg and on a trip to the point marked as the dividing line between Europe and Asia. As we toured the city, Naumkin 
shared some of his childhood memories of growing up there, and took us to the theater where his parents had worked. These personal reflections fostered an open and welcoming atmosphere for our focused discussions on tense areas of US-Russian relations.

We thanked Naumkin as visitors from the US for creating such a welcoming environment for our difficult discussions, and we asked how we might be just as welcoming as we planned the next dialogue in the US. I offered Bar Harbor, Maine, as a potential location for our summer meeting, and explained that my grandmother had lived near there and that I would want to host the group for an informal lobster dinner at her home. To my surprise, we ended up meeting in Bar Harbor the next summer. I moved all the furniture out of my grandmother's living room so that we could sit at folding tables for a group lobster dinner. I shared stories of my grandmother and of visiting her every summer when I was a child. Several brave souls swam in the cold Atlantic Ocean. Others walked the shore. We built a fire after dinner and had an informal visit that set an equally informal tone for days of discussion about difficult topics in the US-Russian relationship.

\section{Opening Up}

Opening up with personal connections in peacemaking can feel a bit risky. It goes beyond the expected distant, western professionalism and brings the whole self into a relationship. But, time and again, I have seen personal openness create the space for serious discussion. I recall once facilitating a discussion with influential people (former and several current officials) from an area that had recently experienced war, and was in danger of renewed fighting. I promised to keep the meeting confidential, so I am not naming the place here. It was a tense time for people to be meeting across the divide, and each of the individuals took a risk in coming to the discussion. Their reputations could have suffered severely, impacting their livelihoods and families, if anyone had chosen to leak details of the meeting, particularly if someone had chosen to contrive an unflattering report of the discussions there. As I went to the meeting place, I noticed a tightness in my stomach. I was nervous and keenly aware of the risks everyone was taking.

When I left home I had taken with me a large box of chocolates, each individually wrapped. I had no plan in mind other than a thought that chocolate could augment the meeting's coffee break, and I wanted to bring something to the meeting and not arrive empty-handed. I had seen other women convening peacemaking dialogues arrive with some sweets as sort of gift to the group. Paula Garb often brought a box of See's candies with her to share at dialogues, placing them out with the coffee break. But by the time I arrived, I felt ready not only to share those chocolates but also to let the chocolates serve to open acknowledgment of the risks each of the participants was taking by coming to talk. Rather than quietly place the chocolates with the coffee break, I placed the chocolates in a bowl on a table in 
our meeting room, and said that these were gifts to each of them, to honor the sacrifices, risks, and efforts they had taken to attend the meeting. And I asked them to feel free to gift chocolates to each other as they heard someone speak from their heart, taking risks to share openly on difficult issues. As I explained this new facilitation technique - thanking others for speaking by giving them chocolates - I had that sinking feeling in my stomach again. Here I was taking a tiny risk, putting out a potentially silly chocolate exercise with some people who were senior current and former diplomats. But they embraced it! The chocolates added a modest sense that we all cared for each other. Some took chocolates as they wanted one; others gave chocolates to people from across the deep political divide; and some just spoke with the caring acknowledgment that each person in the room had made a serious step toward peace by coming to the discussion.

Later, one of the participants in that session shared with me his sense that the chocolates exercise was transformational. It had, he observed, brought the diplomats and officials out of their official roles and into being people with each other, able to connect at a human level, acknowledging each was both there carrying a professional role and also each was at heart a human being. That opening, he said, had shaped the tone. As I reflect on this, I recall feeling deeply in the moment the risks participants were taking by being there and feeling moved to take the risk of openly acknowledging those risks. I realized I might be nervous being a little silly with chocolates, but these peoples were clearly nervous dealing with previous and potential warfare between their nations. I felt we connected with each other as human beings, acknowledging our shared experience of uncertainties. I have grown to appreciate the sense of uncertainty in peacemaking processes. When we are certain what will happen, that usually is not something transformative. Transformation unfolds only when we cannot be certain how a conversation will go. Uncertainty is a gift that invites transformation. Peacemaking requires taking a chance.

\section{Taking a Chance}

From 1999 to 2001 I was part of the Carter Center's conflict resolution team. One of our focuses during that time was convening discussions among senior officials from two countries arranging a new relationship. In 1999, the countries agreed to the overall parameters of their relations. In January 2000, Joyce Neu, Tom Crick, William Ury, and I facilitated a session that worked out details of the plans for implementing that agreement. Those plans set in motion ongoing consultations to shepherd the full implementation of the agreement.

In one of these subsequent meetings, we sat in a small conference room in the Carter Center in Atlanta, Georgia. My colleague Ben Hoffman steered the agenda to consider commitments each participant would make before going home, but that morning the individuals in the room resisted making 
firm commitments. It was as though no one wanted to be the first to commit. Even relatively small steps, such as meeting again in a set period of time, were on the table but not definitively resolved. As I wrote tentative next steps on the flipchart, my colleague sought firm agreements. The participants were silent, looking down and avoiding eye contact. So, my colleague took a chance. He told participants that we would break for lunch and report to President Carter during the break. We would reconvene after lunch, and we might have a message from President Carter at that time. This was a bit of a risk. My colleague was not certain that President Carter would be available to meet with the group or even to send a message by the time we reconvened after lunch. But he took a chance, knowing that even if the timing didn't work for meeting just after lunch, President Carter would certainly join the group at the end of the day to bid farewell, as scheduled. The participants went to the dining room for lunch, while my colleague and I prepared a message for President Carter, outlining our progress and the tentative commitments we hoped would become firm decisions.

After lunch, President Carter did indeed join the group, summarized his understanding of the agreements that I had written on the flip chart, and asked each person, looking around the room and making eye contact with each one, if there was anything on the list that they would not commit to. In contrast to the session before lunch, everyone was now suddenly in agreement. President Carter thanked them all for taking brave steps to implement the next phase in the changes their countries had agreed to.

As I watched this conversation unfold, I was struck by the power of the lunch break, which created time for participants to consider the commitments, and the power of Jimmy Carter as the former President of the United States. I was struck also by the creative approach in the moment of calling on President Carter to meet with the group earlier than planned. The improvisational lunch break element of the process had afforded participants time to consider their commitments, and also given them a face-saving way to agree: when they went home, they could explain their agreements as respectful deference to senior statesman President Carter. I also appreciated President Carter's having flipped the question from asking what on the list the participants would agree to, to asking what on the list the participants would not agree to. Shifting the emphasis shifted the possibilities. The meeting ended a few hours later, with many details clarified and specific next steps set in motion.

These examples of personal relationship building and informal spontaneity and improvisation are numerous, as each significant peacemaking dialogue I have engaged in has included some of these elements. Similarly, I could present many examples of nerves and anxiety as I headed toward a peacemaking meeting, and examples of taking a chance and not having control over the outcome of a process. It seems that when I'm not confident about how the meeting will go there is greater potential for really meaningful shifts, because that's when I'm taking a risk, and opening myself to the uncertainty of what may emerge in the peacemaking process and space. 


\section{Psychology of Peacemaking Processes in Estonia}

Elsewhere, I have described how psycho-political dialogue can contribute to conflict prevention, drawing on the experience of the Center for the Study of Mind and Human Interaction (CSMHI), led by Dr. Vamik Volkan (Allen 2016). The psychological or psychodynamic approach emphasizes the person as part of the peacemaking process. This emphasis on the person shapes the process to a people-centered process. Rather than focus immediately on policies and conflict actions, in a psychodynamic approach, there is a focus on the psychology that shapes those policies and actions. The psychodynamic approach foregrounds the individual and group psychological dynamics, and considers these in the political and conflict context.

I first met Vamik Volkan in December 1994, when I interviewed him at his office (Volkan 1994). At the time, the offices of the Center for the Study of Mind and Human Interaction filled a pleasant brick house tucked away on a wooded hill in the Blue Ridge Hospital complex near Charlottesville, Virginia. Part of the University of Virginia Medical School, CSMHI's work and research focused on the psychological aspects of international conflict. Volkan, a psychoanalyst, directed CSMHI from a sunny corner room in the house. His studies of the psychology of groups in conflict were a cornerstone for CSMHI's work.

In my interview with Volkan I focused on learning about his and his colleagues' work on Estonian-Russian relations. The Baltic states - Estonia, Latvia, and Lithuania - share in common aspects of their relations with Russia, although they each have their own unique histories with the country as well. Estonia and Latvia were ruled alternately by Germans, Swedes, Danes, and Russians, until they gained full independence between World War I and World War II. Russia ruled Lithuania from the 18th century on, until the Poles gained control from World War I to World War II but, in contrast to its northern Baltic neighbors, Lithuania was a sovereign state and equal partner in the Polish-Lithuanian Commonwealth for centuries prior to Russian rule. Each of the Baltic states was incorporated into the Soviet Union as Soviet Socialist Republics in 1944. Many Balts consider this the occupation of independent states by a hostile state, but some Russians consider it the liberation of the Baltic states and their subsequent acceptance into a voluntary union.

In this historical context, changes that ensued after the 1991 independence declarations of the Baltics unveiled a complex conflict between Russian and Baltic conceptions of past, present, and future relations.

The conflict manifests itself in the substantive policy issues confronting the Balts and Russians as they try to create a new relationship. These include the contentious issues of citizenship, voting rights, language requirements for citizenship and employment, border disputes, Russian troops stationed in the Baltic states, Kaliningrad region issues, residency permits, and travel documents. 
Each Baltic state has addressed these issues according to their individual circumstances, but some common themes have emerged in Baltic attitudes toward the Russian influence in the region, and in Russian attitudes toward the Baltics. For example, while Lithuania granted automatic citizenship to the mere nine percent of the population that immigrated to Lithuania during the Soviet period, Latvia and Estonia granted automatic citizenship only to the two-thirds of the population that either had citizenship in the prewar republics or were the direct descendants of such citizens. Yet all three vocally supported each other's calls for the withdrawal of Russian troops from their territory and legislated minimum language requirements for workers in selected professions. On the Russian side, Russian foreign ministry officials grouped the Baltics together as states that violated the human rights of Russian speakers.

The conflicts between the Baltics and Russia, and especially between Estonia and Russia, have attracted attention from Track One level interveners, in addition to CSMHI's Track One and a Half and Track Two work. Track One interveners have done "preventive diplomacy" work on the part of the OSCE and western embassies. Michael Lund defines preventive diplomacy as "deliberate efforts to keep the political disputes that emerge out of the instabilities, insecurities, and clashing of interests that are caused by rapid international and national change from taking the form of major armed confrontations, violent conflicts or other coercion as the mode for their 'resolution"' (Lund 1996).

International attention focused more specifically on Estonia, as tensions were higher there. These were most noticeable in the summer of 1993, when the Estonian government enacted the controversial Law on Aliens and Citizenship that required non-citizens to apply for residency permits, leaving most of the Russian-speaking population without travel documents and facing deep uncertainties about their future in Estonia. I visited Estonia for one month in summer 1993. I split my time between the Russian and Estonian communities, as I led US summer camp children first to a Russianspeaking camp and then to an Estonian-speaking camp in Estonia. Many long conversations with Russian and Estonians helped me make sense of the work of CSMHI and other interveners doing peacemaking in Estonia.

Volkan's psychodynamic theory underpins much of this work. Volkan holds that people have a Need for Enemies and Allies (Volkan 1988), which he explains based on a psychoanalytic theory of human development. Early in development, children are not cognizant of partially good and partially bad entities outside of themselves, but see entities as either entirely good or entirely bad. For example, the mother who runs to feed the child is all good and the mother who does not immediately relieve the child's hunger is all bad. The child "retains unintegrated good and bad self- and object representations" (Volkan 1988, 30), Volkan writes. As the child develops, certain entities externalize that which is bad. Some of these entities are objects that serve the externalization function for all children growing up in 


\section{Process Shapes People-Centered Peacemaking}

the same culture. These psychological processes are crystallized in adolescence, creating part of a group identity and a shared pool of targets that a group may consider entirely bad during times of mass regression, perhaps in response to a threat to group identity.

Volkan does not argue that shared cultural symbols are all negative projections--positive projections also occur. When some projections, either positive or negative, are reinforced socially during adolescence, those projections become a cultural resource that can be called on in times of group stress. They are part of the group identity, which Volkan aptly describes metaphorically:

Think in terms of learning, from childhood on, to wear two layers of clothing. The first garment, which belongs just to the individual who is wearing it, fits him snugly. The second set of clothes, the ethnic layer, is a loose covering that protects him like a mother or other caregiver... it as though it were one big canvas tent.... As long as the tent remains stable and strong, the members of the group can go about their lives without paying much attention to it. If the tent is disturbed or shaken, however, this attracts more notice, and all the individuals under the tent collectively become preoccupied with trying to make the tent strong again. (V. Volkan 1992, 8)

Volkan explains that the ethnic tent houses shared symbols, rituals, and psychological coping mechanisms that people turn to when they perceive that their "tent," or identity, needs defending. These coping mechanisms include competition rituals, deterrence rituals, rituals of minor difference, border rituals, chosen traumas, chosen glories, dehumanization, and victimization (Volkan 1992). The ritual mechanisms help groups under stress differentiate themselves from others by competing with others, seeking to deter others, fixating on otherwise insignificant differences between groups, and paying irrational attention to borders between groups. Chosen traumas and glories are events drawn into a group's mythology and very identity, and thus passed from generation to generation. Dehumanization and victimization refer to even more sharply-drawn lines between one group and another in support of the ethnic tent. These processes may be so extreme that the others are no longer considered human and thus may be victimized without remorse or guilt. These psychological perspectives clarify that irrational processes are at work in conflict situations between groups.

Volkan holds that irrational aspects of the conflict must be addressed before the rational aspects. If the irrational aspects are not first addressed then the substantive issues cannot effectively get solved because rituals, symbols, traumas, and the like will make any substantive suggestions psychologically unacceptable.

Volkan highlights how psychoanalysts can unveil and expose hidden meanings in events (Volkan 1994). For example, when the ferry Estonia sank 
on September 28, 1994, the nation was shocked at the tragedy. Volkan argues that only psychoanalytic insight could bring out Estonians' deep and "hidden" fear of disappearing, or sinking to the bottom, just as the ship sank. Participants at a CSMHI meeting in Tallinn, just a week after the ferry sank, discussed this fear. Baltic participants expressed shame at the disaster, because it in some way it reflected the Estonia's inability to survive as an independent, industrialized country. They identified their country with the foundering boat.

In my experience, elicitive long-term conflict resolution work - with deep engagement in a cultural context, long talks with many people in a community, and listening and learning - can also yield insights into some of the underlying significance of events. For example, as I read about the sinking of the ferry boat the Estonia, I immediately felt its significance for all those Estonians who had shared with me in talks by the campfire or water, or over a cup of tea, precisely their fear that Estonia (the country) would just disappear, and sink into the sea. As a titular nation with a narrow majority in a small country, with a language unknown to many, neighbored by a huge country (Russia) where the titular ethnic group's language (Russian) dominates in many countries, Estonians worried that their ethnic group would disappear.

\section{Process Choices in CSMHI Baltic Peacemaking Dialogues}

When I interviewed Vamik Volkan in December 1994, CSMHI had sponsored four meetings in the Baltics and planned to hold additional meetings. The first meeting was in Kaunas, Lithuania in April 1992. After that, CSMHI groups also met once in Riga and twice in Tallinn. The final Baltic CSMHI meeting (at least at the time of my interview in December) occurred in Tallinn in October 1994.

CSMHI teams hoped to serve as "catalysts to identify impediments to peaceful relationships in the region and to bring to light possible solutions to national and ethnic problems" (Volkan and Harris 1992, 20). The meetings' goal was not to fully resolve the conflict, but to remove psychological resistances among participants to rational analysis of the conflict, and subsequent rational analysis of the conflict and possible settlements. The CSMHI Baltic meetings had a common basic structure, described by one observer as "a hybrid of group therapy, diplomatic conference, and academic seminar" (Cullen 1993, 32). Each meeting brought together approximately 30 key political players and scholars in the Baltics and Russia with a team of approximately ten CSMHI associates for four days of discussions. The one hosting Baltic state contributed more participants than the others, although each Baltic state was represented at each meeting. Discussions centered around Russian-Baltic relations, including ethnic relations within the Baltic states, but focused more on the hosting state for that particular meeting. The agenda was flexible according to the progress of the discussions. The schedules included both plenary and small group 
sessions facilitated by experienced CSMHI faculty. Between scheduled sessions, the whole group ate communally for lunch and dinner and spent time together informally.

The Baltic meetings thoughtfully operationalized the CSMHI's psychoanalytical and theoretical underpinnings, with many process choices dictated by those underlying theories. However, while CSMHI's efforts strongly unify theory and practice, the psychoanalytic insights that drive the basic approach do not dictate every practical design choice in the meeting planning. Some decisions during the planning stages may be pragmatic and practical, with no explicit theoretical underpinnings.

As one clear example of CSMHI's practice, I concentrate here on the October 1994 Tallinn meeting - the second CSMHI meeting in Estonia. Some of the participants of that meeting attended the previous CSMHI meeting five months before. The October meeting involved mid- and highlevel leaders linked to the Estonian government, the Russian community in Estonia, the Russian government, and several other Baltic participants.

CSMHI focused on small group sessions, during which more personal issues were discussed. Volkan explained that the bulk of the work on psychological resistances to resolution can occur in small sessions (Volkan 1994). Each group was facilitated by a psychoanalyst. However, CSMHI tailored the meeting to the high-level participants and their expectations for large plenary discussions that resembled a more traditional analytical workshop. According to Volkan, less important work occurred in the plenary sessions. This again reflects the CSMHI tendency to view conflict as centrally a psychological phenomenon and to place less emphasis, accordingly, on the behavior and substantive issues that might be discussed in plenary.

The perspectives that emerged during the small group sessions add an important psychological component to the understanding of the conflict. As described above, Estonians feared that they might fail as a state and disappear. These fears inspired the stringent language requirements enacted by the Estonian government to ensure that the Estonian language would not disappear. Further desires for a mono-ethnic Estonian nation-state surfaced. Russians reacted to these feelings and expressed their own feelings of outrage that the people who had brought the country into the industrialized world would now be pushed out of it. Furthermore, Russians described themselves as separate from the Soviet regime, under which they had suffered and been victimized, too. Russians in Estonia described their humiliation when they faced unstandardized and seemingly purposefully very difficult Estonian language exams. Clearly, these psychological components of the conflict deepen our understanding of the psychological processes that influence the current situation. Such an understanding is undoubtedly important for eventual resolution.

The Estonian-Russian relationship in Estonia can be seen as an asymmetric conflict in many ways. The Russian community in Estonia felt dominated by the titular ethnic group, the Estonian majority. At the same 
time, the Estonian community felt the presence not only of a sizable Russian minority in Estonia but also of a very larger Russian state to the east. In an asymmetric conflict, peacemaking processes will not be effective long-term if they allow the stronger party to dominate.

This experience corresponds to the Georgian-South Ossetian relationship, where each party sees another as the dominating larger power. Many Georgians see Russia as the main dominator, not only there but also in South Ossetia. Some Georgians contend therefore that there is no reason to negotiate with South Ossetians, because, they think, there is no room for South Ossetians to make any negotiation decisions independent of Russia.

Kolb and Kolb note a basic similarity between psychoanalysts and conflict resolution interveners: "Mediators, like psychiatrists, must loan some of their problem-solving capacities to their clients on the spot" (Kolb and Kolb 1993, 337). And mediators, like psychiatrists, can only open up directions of movement for the parties of a conflict, not single-handedly make the parties move in those directions. The intervener's skills enable the parties themselves to move toward resolution. Peacemaking is about supporting people in making their own peace.

This emphasis on individual people in conflict who choose to make their own peace should serve as a warning against the increasing professionalization of the conflict resolution field. Professionalization may limit the effectiveness of some conflict resolution work, because effective conflict resolution involves communicating skills that over time may build long-term peace. If the convener of a conflict analysis workshop does not enable participants to use the skills modeled at the workshop when they return to their own communities then the impact of the workshop will be less far-reaching.

\section{People Taking Preventive Diplomacy Approaches in Peacemaking in Estonia}

In his concept of preventive diplomacy, Michael Lund focuses on Track One efforts, in which the key actors are institutions and governments. This specific slice of preventive diplomacy leaves out other interventions such as problemsolving workshops, nongovernmental interventions, and even cultural exchanges. The Samantha Smith Exchange that brought me to Estonia also brought a group of ten youngsters from Estonia to the United States for a month of summer camps. The group from Estonia included both Estonians and ethnic Russians living in Estonia. The children reportedly grew close over the month in the United States. The exchange, while structured around a primary goal to encourage understanding between Americans and Estonians, also encouraged understanding between Estonians and Russians by placing them together for a month. As this example suggests, preventive diplomacy might also include various track one and a half, track two, and people's diplomacy efforts, too. This returns us to a people-centered approach to peacemaking and preventive diplomacy. 
For example, Max van der Stoel was a Dutch politician who was credited individually with significant contributions to the prevention of escalating conflict between Estonians and Russians in Estonia in the early 1990s. He was appointed as the first High Commissioner for National Minorities (HCNM) of the Conference on Security and Cooperation in Europe (CSCE), which soon became the Organization for Security and Cooperation in Europe (OSCE). As an individual Max van der Stoel has played a unique role in Estonian-Russian relations in Estonia (Huber 1994). His personal reputation at times afforded him respect and influence, in addition to that conveyed simply through his office. In this manner, van der Stoel, representing Western human rights standards, made it more politically acceptable for the Estonian government to enact policies that might otherwise be seen as bowing to Russian demands. Van der Stoel occasionally served as a scapegoat for the Estonian government as the reason that they must concede to some of the Russian demands. Van der Stoel was personally singled out for criticism by the Estonian press more than the CSCE (later OSCE) organization as a whole, especially after his meetings with "radical" Russian leaders in the northeast (Erath 1994).

As Estonia turned toward the west, seeking to gain acceptance as a part of Europe, Estonian political leadership gave the CSCE a significant, though certainly not complete, degree of legitimacy and authority on standards of human rights. Estonian President Lennart Meri's submission of the Law on Aliens to the CSCE for review, for example, was an individual choice that demonstrated his interest in validating Estonia's accordance with western standards, as represented by the CSCE. The Estonian government response to the previous Report of the CSCE Offices for Democratic Institutions and Human Rights included "assurances of their highest considerations" ("Report of the CSCE ODIHR Mission on the Study of Estonian Legislation Invited by the Republic of Estonia" 1993).

US Ambassador to Estonia Robert Frasure was also active in the early 1990 s to prevent escalating Estonian-Russian tensions. Ambassador Frasure enjoyed a good relationship with both the Estonian government and the Russian community. He often worked in coordination with other parties, especially staff at the CSCE Mission, both eliciting support from the Mission for US initiatives and giving US feedback on and support to CSCE projects. He secured US and Swedish funding of the administrative costs of the President's Roundtable (an initiative that brought together Estonian and Russian elite in Estonia). The CSCE had urged him to do so but the idea was not accepted by the Estonian government until the crisis of the summer of 1993 (Erath 1994). Similarly, the partial US funding of Estonian language classes in the predominantly Russian-populated region of Sillamea happened through collaborative CSCE-US work, with Robert Frasure's personal engagement. Frasure also suggested the compromise of "temporary travel documents" in lieu of passports for Estonian's non-citizen population, which holds no other valid passport (Erath 1994). The CSCE then supported 
this compromise measure. Ambassador Frasure went on the serve as Deputy Assistant Secretary of State for European and Canadian Affairs in the US State Department, and died in August 1995 in a car accident on a treacherous mountain road in Bosnia, where he was actively negotiating an end to the fighting there.

Other individuals have also publicly urged constructive actions to deescalate Estonian-Russian tensions in Estonia. In September, 1993, Pope John Paul II, having learned the Estonian language, spoke publicly in Tallinn - in Estonian - to support understanding and coexistence with the Russian minority in Estonia. In November 1992 Jimmy Carter told Ostankino TV that the US was witnessing human rights violations in Estonia and Latvia, but US Senator Richard Lugar quickly followed up to explain that Carter was stating his own private views. Former President Richard Nixon wrote an editorial in support of the human rights of the Russian community in the Baltics overall.

The tensions as well as the peacemaking possibilities in the EstonianRussian context can also be seen in the experiences of individual teenagers who embarked on the Estonian part of the US-Estonian exchange organized by the Samantha Smith Memorial Foundation in 1994. As I was in Tallinn, having brought US teenagers on that exchange, the Estonian group, including ethnic Russian and ethnic Estonian teens, was preparing to travel to the US. Three of the ethnic Russians did not yet have the travel documents that would allow them to enter the US. When I spoke with a senior Estonian diplomat that July, just ten days before the group planned to travel, he explained that the three ethnic Russian teens should have gotten Russian passports if they wanted to travel abroad. The same diplomat asked me, apparently in a sincere attempt to understand, to explain what the Russian community really wanted in Estonia. I had two summers of experience in Estonia, only half of that embedded in the Russian community. But, she trusted my perceptions more than her own understanding, she said, as she knew only a few ethnic Russians personally. She seemed surprised to hear that the ethnic Russian people I had met in Estonia wanted to be Estonian citizens and considered Estonia their home. Likewise, the three teens who were preparing to travel to the US on the exchange program wanted Estonian passports, as Estonia was their home and they considered themselves Estonian citizens. The stories of teenagers in Estonia reflect part of the peacemaking story of Estonia-Russian relations.

In the next chapter, we examine stories of people building peace in their own contexts, and connecting their work to regional and global dynamics.

\section{Works Cited}

Alborova, Dina, Susan Allen, and Nino Kalandarishvili, eds. 2016a. Cost of Conflict: Core Dimensions of the Georgian-South Ossetian Context. Fairfax, Virginia: George Mason University and the Alliance for Conflict Transformation. 
Alborova, Dina, Susan Allen, and Nino Kalandarishvili, eds. 2016b. Cost of Conflict: Untold Stories, Georgian- South Ossetian Conflict in People's Lives. Fairfax, Virginia: George Mason University and the Alliance for Conflict Transformation.

Allen Nan, Susan. 2008. "Conflict Resolution in a Network Society." International Negotiation (Hague, Netherlands) 13 (1): 111-31. 10.1163/138234008X297995.

Allen, Susan H. 2016. "Estonia: Psychopolitical Dialogue Contributing to Conflict Prevention." In Across the Lines of Conflict: Facilitating Cooperation to Build Peace, edited by Michael Lund and Steve McDonald, 53-84. New York: Columbia University Press.

Arai, Tatsushi. 2015. "Engaging Conflict History: Toward an Integrated Method of Conflict Resolution Dialogue and Capacity Building." Conflict Resolution Quarterly 32 (3): 277-98. 10.1002/crq.21113.

Carl, Andy. 2021. Peace Talks. https://factr.com/g/co-curators/peace-talks.

Cullen, Robert. 1993. "Cleansing Ethnic Hatred." Atlantic Monthly, August.

Dahir, Abdi Latif. 2021. "Somalia Moves to Defuse Tensions at Home and Abroad." New York Times, May 7, 2021. https://www.nytimes.com/2021/05/06/ world/africa/somalia-kenya-diplomatic-relations.html.

Diamond, Louise. 1991. Multi-Track Diplomacy: A Systems Guide and Analysis. Grinnell, Iowa: Iowa Peace Institute.

Dugan, Maire A. 1996. "A Nested Theory of Conflict." A Leadership Journal: Women in Leadership- Sharing the Vision 1 (July): 9-20.

Elder, C. 2016. "Participatory Action Research (PAR), A Tool for Transforming Conflict: A Case Study from South Central Somalia." Life and Peace Institute. http://life-peace.org/wp-content/uploads/2016/07/Somalia_PAR_WEB-1.pdf.

Erath, John. 1994. Interview by the author, July 15, Tallinn, Estonia.

Fisher, Ronald J. 2020. "Transfer Effects from Problem-Solving Workshops to Negotiations: A Process and Outcome Model." Negotiation Journal 36 (4): 441-70. 10.1111/nejo.12336.

Gamaghelyan, Philip. 2017. Conflict Resolution beyond the International Relations Paradigm: Evolving Designs as a Transformative Practice in Nagorno-Karabakh and Syria. Soviet and Post-Soviet Politics and Society, Vol. 171. Stuttgart: Ibidem-Verlag.

Huber, Konrad J. 1994. "Averting Inter-Ethnic Conflict: An Analysis of the CSCE High Commission on National Minorities in Estonia, January-July 1993.” Working Paper Series, Carter Center Conflict Resolution Program. Atlanta, Georgia.

Jones, Peter L. 2015. Track Two Diplomacy in Theory and Practice. Stanford, California: Stanford University Press.

Kolb, Deborah M. 1994. When Talk Works: Profiles of Mediators. 1st ed. The Jossey-Bass Conflict Resolution Series. San Francisco: Jossey-Bass.

Kolb, Deborah M., and Jonathan E. Kolb. 1993. "All the Mediators in the Garden." Negotiation Journal 9 (4): 335-39. 10.1007/BF01000307.

Lund, Michael S. 1996. Preventing Violent Conflicts: A Strategy for Preventive Diplomacy. Washington, DC: United States Institute of Peace Press.

Marks, Susan Collin. 2009. "Peace Practices Interview by Susan Allen Nan."

Medland, William J. 1990. "The Cuban Missile Crisis: Evolving Historical Perspectives." The History Teacher 23 (4): 433-47. 10.2307/494397.

Meisler, Stanley. 1988. "Reagan and Gorbachev: Warming of a Relationship." Los Angeles Times, June 2, 1988. https://www.latimes.com/archives/la-xpm-1988-0602-mn-5847-story.html. 
Mitchell, Christopher, and Michael Banks. 1996. Handbook of Conflict Resolution: The Analytical Problem Solving Approach. New York: Pinter.

Montville, Joseph. 1987. "The Arrow and the Oliver Branch: The Case for Track Two Diplomacy." In Conflict Resolution: Track Two Diplomacy, edited by John McDonald and Diane B Bendahman, 5-20. Washington, DC.: Foreign Service Institute, State Department.

Montville, Joseph. 1991. "Transnationalism and the Role of Track Two Diplomacy." In Approaches to Peace: An Intellectual Map, edited by Scott Thompson and Kenneth Jensen, 254-69. Washington, D.C.: United States Institute of Peace Press.

Nan, Susan Allen. 1999. "Complementarity and Coordination of Conflict Resolution Efforts in the Conflicts over Abkhazia, South Ossetia, and Transdniestria." Doctoral dissertation. Fairfax, Virginia: George Mason University.

Nan, Susan Allen. 2004. "Track One and a Half Diplomacy: Searching for Political Agreement in the Caucasus." In NGOs at the Table: Strategies for Influencing Policies in Areas of Conflict, edited by Mari Fitzduff and Cheyanne Church, 57-75. Lanham, Maryland: Rowman \& Littlefield.

Nan, Susan Allen. 2005. "Track One-and-a-Half Diplomacy: Contributions to Georgian-South Ossetian Peacemaking." In Paving the Way: Contributions of Interactive Conflict Resolution in Peacemaking, 161-73. Lanham, Maryland: Lexington Books.

Nan, Susan Allen. 2009. "Social Capital in Exclusive and Inclusive Networks: Satisfying Human Needs through Conflict and Conflict Resolution." In Social Capital and Peacebuilding: Creating and Resolving Conflict with Trust and Social Networks. Routledge Studies in Peace and Conflict Resolution. New York: Routledge.

Nan, Susan Allen. 2011. "Consciousness in Culture-based Conflict and Conflict Resolution." Conflict Resolution Quarterly 28 (3): 239-62. 10.1002/crq.20022.

Nan, Susan Allen, and Greiff, Jacquie L. 2013. "Basic Human Needs in Practice: The Georgian-South Ossetian Point of View Process." In Conflict Resolution and Human Needs: Linking Theory and Practice, edited by Kevin Avruch and Christopher Mitchell, 202-15. New York: Routledge.

"Reflecting on Peace Practice (RPP) Basics. A Resource Manual." 2016. CDA Collaborative Learning Projects. https://www.cdacollaborative.org/wp-content/ uploads/2017/01/Reflecting-on-Peace-Practice-RPP-Basics-A-Resource-Manual.pdf.

"Report of the CSCE ODIHR Mission on the Study of Estonian Legislation Invited by the Republic of Estonia." 1993. Conference on Security and Cooperation in Europe.

Romano, Arthur, Emily K Linnemeier, and Susan H Allen. 2021. "Conflict Resolution in Activist Networks: Reflections on Prework, Power, and Engaging with Change in Appalachia." Conflict Resolution Quarterly n/a (n/a). 10.1002/ crq. 21303.

Saunders, H. 2006. Politics Is about Relationship: A Blueprint for the Citizens' Century. New York, United States: Palgrave Macmillan US. http://ebookcentral.proquest. com/lib/gmu/detail.action?docID=308041.

Saunders, Harold H. 1982. Conversations with Harold H. Saunders: U.S. Policy for the Middle East in the 1980s. AEI Studies 346. Washington: American Enterprise Institute for Public Policy Research.

Saunders, Harold H. 2003. "Sustained Dialogue in Managing Intractable Conflict." Negotiation Journal 19 (1): 85-95. 10.1111/j.1571-9979.2003.tb00282.x. 


\section{Process Shapes People-Centered Peacemaking}

"South Ossetia: Activist Brutally Assaulted." 2010. Human Rights Watch. July 26, 2010. https://www.hrw.org/news/2010/07/26/south-ossetia-activist-brutally-assaulted.

Volkan, Vamik. 1992. "Ethnonationalistic Rituals: An Introduction." Mind and Human Interaction 4 (1): 3-19.

Volkan, Vamik. 1994. Psycho-dynamic Approaches to Conflict Resolution Interview by Susan Allen.

Volkan, Vamik D. 1988. The Need to Have Enemies and Allies: From Clinical Practice to International Relationships. Northvale, N.J.: Jason Aronson, Incorporated.

Volkan, Vamik, and Max Harris. 1992. "Negotiating a Peaceful Separation: A Psychopolitical Analysis of Current Relationships Between Russia and the Baltic Republics." Mind and Human Interaction 4 (1): 20-39.

Wright, Oliver, and Bruno Waterfield. 2021. "Johnson and Macron Plan Peace Talks; Continued from Page 1 PM and Macron Peace Talks." The Times (London), May 7, 2021. 


\section{Locals Lead with Global Awareness}

This chapter returns to the Georgian-South Ossetian context again to explore the meaning of local leadership in peacemaking and partnerships between global and local peacemakers. The idea of local leadership in peace processes historically has been overshadowed by an emphasis on impartial, international leaders and global, geopolitical perspectives. But the Georgian-South Ossetian conflict demonstrates, as do other contexts, that local peacemakers have a sort of legitimacy in their communities that is only possible when someone lives long term in the community. Their colleagues and compatriots know that these peacemakers will have to live with the results of their peacemaking efforts. In addition to this kind of legitimacy, the stories below illustrate how the local expertise and relationships that Georgian and South Ossetian peacemakers brought to the process crucially contributed to discrete successes and achievements.

This chapter emphasizes that in peacemaking practice, culture and context matter a great deal - both local and global contexts, and the two in relation to each other. It presents some ways that locals lead within peacemaking processes that are embedded in global dynamics, and compares and contrasts the strengths and constraints of locals and internationals involved in the process by examining several locally-led initiatives. Experience from multiple contexts recommends that peacemakers build constructive partnerships and shared leadership between insiders and outsiders - between locals and internationals - to design and implement multifaceted peacemaking processes. This approach is consistent with the idea of a "network society," in which we are all implicated and connected, and with the nested model of conflict. In all of the cases described here, peacemaking has persevered, and it has adapted to the shifting boundaries of the possible.

Many international peacemakers' experiences demonstrate that deep cultural knowledge built over many years supports constructive, culturallysensitive peacemaking practice. In cases where insiders do not lead, then outsiders' leadership must at least bring strong cultural awareness.

Time and again I have realized that I will always have much to learn from locals who live their conflicts daily. When I first assisted Paula Garb in the Georgian-Abkhaz dialogue I re-learned this lesson of humility, having 
joined the process with a great deal of naivete and without a nuanced understanding of local conflict resolution conversations. My subsequent experiences have only reinforced that lesson of humility.

We had gathered in the town of Adler, near Sochi, with Georgians and Abhaz who were pioneering the civil society-based dialogue in their context. The evening before the dialogue began Paula had urged me to speak up and share with her ideas from my facilitation training that would help her lead the conversation effectively. I hesitated, explaining that I didn't know the participants or the context as well as she did. But I agreed to pass her notes when I saw facilitation opportunities.

We met in a hotel that had a meeting room barely large enough for our group. The table itself almost filled the room, and participants consumed most of the remaining space as we took our seats around the table. Each of us could sit around the table, elbow to elbow, but we had no room to scoot our chairs back and step away, as we were so close to the walls that we could not navigate around the table with others seated there. We began the meeting after breakfast at about 9:30 am with a plan to work, take a break, and then work again until lunch, which was probably scheduled for $1 \mathrm{pm}$. I figured we'd take our break around 11 or 11:30.

The conversation focused on the goals of that dialogue series and, one by one, participants shared their goals. The clock ticked, and I realized it was 11:30. One of the smokers was at a corner of the table where there was space for him to stand up, go to the door, and blow smoke out the door while still listening in on the meeting. I slid a note to Paula across the table: "Break time?" She took the note, read it, and continued the discussion. We were approaching 12 o'clock and we were scheduled to have lunch in an hour. I needed a bathroom break. I wrote another note to Paula, "I need a bathroom break, but I can't get up and leave the table without three other people also standing up." She took the note, read it, and then said, "If anyone needs a break, let's let them out. The rest of us can continue." The people seated between myself and the door stood, making way for me to leave. I was the only one who left. Another participant came to the doorway, listening to the conversation while smoking. I returned a few minutes later and the conversation continued through and beyond $1 \mathrm{pm}$. Finally, we went to lunch about 20 minutes late.

Over lunch, Paula checked in on me. Was I feeling ok? I explained that I had intended to help by sharing a tip from my facilitation training: allow frequent breaks for informal conversation and don't make people sit for more than two hours in focused conversation. I was trying to encourage us to keep to our plan of taking a short break mid-morning, following an abstract "rule" of facilitation design that I'd acquired in my studies. Paula explained her sense that the conversation was so important to the participants that no one wanted to interrupt it before everyone had had a chance to speak. It was the first time they had ever spoken this openly with each other, and they didn't want to disrupt the flow of conversation with a break. Stuck in my head, thinking 
about our plans, and less focused on what was unfolding than on what we had planned for, I hadn't intuited the essence or special facets of the conversation. I hadn't felt the importance of the developing conversational dynamics, and flow. I had missed it because I was focused on a recipe of sticking to the plan and taking breaks every two hours.

Years later, when we had grown into close colleagues, Paula confessed she had been truly annoyed with me during that Adler dialogue when I had repeatedly passed her notes about taking a break. As we looked back on that experience, she described her feeling that she was connected at the gut level with the participants, as though a string connected her gut and the guts of everyone else in that room together, and she was feeling their bodies with her body. There was a fullness of conversation that went beyond specific words. Emotions were conveyed inside to inside. While I had been thinking about the words, Paula had been attuned to the feelings in the room. As we talked, Paula connected this listening with her stomach to Warfield's concept of listening with an inner ear. The facilitator when very present to the current moment is attuned to more than the words of the participants. Long after the Adler experience, I wrote about consciousness in conflict resolution practice, noting that the bodily awareness of the facilitator is part of tuning in fully to the dynamics in a conflict resolution dialogue (Nan 2011).

Ever since that experience in Adler, I have tried to recall this lesson and to focus on what is revealed by being in the moment, listening fully. And, I have still tried to keep my training in mind but to offer questions, even simple questions such as asking if the group wants a break, rather than simply imposing breaks and following a set plan. I have also tried to approach plans, abstract tips, and strategies as possible approaches and starting points rather than as ironclad rules - they are places from which to improvise and adjust as needed. And, I have tried to prioritize being in the moment and listening deeply over following an agenda or plan.

This approach has served me well in many years of people-centered peacemaking practice. I have learned to listen to the people I'm working with, appreciating their guidance and the possibilities that emerge in experimenting with approaches that are new to me. Over time, as we all became more comfortable working together, Georgian and South Ossetian coordinators assumed more of the facilitation roles themselves. They have been excellent facilitators, building on their nuanced cultural understandings to draw out insights that I might well have missed. As facilitators, the Georgian and South Ossetian coordinators have led conversations in directions that I didn't know would be possible.

This approach of local leadership contrasts with some of the assumptions in earlier conflict resolution theories of practice. Many models of interactive conflict resolution (Fisher 1997) emphasize that outsiders should facilitate discussions, bringing their international impartiality to the role. The Analytical Problem Solving Workshop approach, for example, recommends a panel of outside experts who together facilitate the workshop, balancing 
each other's diverse perspectives (Mitchell and Banks 1996). Kelman's international scholar practitioner model also engages outsiders as impartial but insightful experts (Kelman 2000).

However, practitioners who have noted the importance of culture in conflict resolution have introduced a new inflection, or even a new era, of peacemaking practice by emphasizing cultural fluency and, in parallel, scholarship that privileges practitioner insights (Avruch 1998). While Georgians and South Ossetians began rotating facilitation roles for parts of their peacemaking workshops, other peacemakers with knowledge of the local culture and language also took leading roles in other processes. For example, the Imagine Center for Conflict Transformation, a non-profit conflict resolution NGO with offices throughout the South Caucasus, has been co-led by peacemakers of Azeri and Armenian ethnic backgrounds. And scholar practitioner Tatsushi Arai, a professor at Kent State University originally from Japan, has co-led multiple workshops focused on the East China Sea with individuals who also represent that region's ethnic and linguistic backgrounds (Arai, Goto, and Wang 2013).

Unfortunately, many Westerners still do not recognize or appreciate the expertise of local peacemakers. I once convened a "reflective practice" session in which US peacemakers joined a developing country's peacemakers to share their experiences with each other. What a culture clash! The developing country's peacemakers came full of questions, dilemmas, and challenges they were facing and wanted to get input on these, while one of the US peacemakers came with a lecture and a PowerPoint presentation about a process he and his colleagues had convened and completed. The US presenter had no questions and wanted no input on anything from the other peacemakers. He suggested that a future session could be focused on the work of the peacemakers from a developing country and that they could present a case about which they wanted advice. This individual had a very unbalanced understanding of reflective practice sharing, so the facilitator at the moment reframed the next session's planning to focus on how the developing country's peacemakers could share their insights to help US peacemakers learn. As we planned for future sessions, the facilitator and I clarified the purpose of mutual learning as a two-way, interactive process.

Culture and local experience matter in peacemaking. Conflict resolution training in the 1990s, at least at what was then George Mason University's Institute for Conflict Analysis and Resolution, emphasized how culture shaped conflict and conflict resolution (Avruch 1998; Lederach 1999; LeBaron 2003; LeBaron and Pillay 2006). In Institute classes, Professor Wallace Warfield taught about listening "with your inner ear" to underlying tones as people in conflict spoke, and staying attuned, especially, to body dynamics and other nonverbal cues and nuances of conflict. Professor Michelle LeBaron led courses on inter-cultural engagement, emphasizing students' developing awareness of their own cultures and biases. Learning from anthropologists and seasoned practitioners, student scholar-practitioners of peacemaking 
studied the cultures in which they engaged, immersing themselves for years in the contexts of their work. As we celebrated the strength of cultural sensitivity in peacemaking we also recognized the importance of long-term engagement, which supports the development of cultural competence over time in a particular context. More recently, Oliver Richmond has highlighted what he calls the "infrapolitics" of peacebuilding (drawing on Scott 1990). This term refers to the "relatively hidden site of agency where culture, identity, agency, and structure from beneath has a significant effect on its more visible mainstream dynamics" (Richmond 2011).

Increasingly, scholars conversant in political science and international relations have given more attention to practitioner practices of engagement with local culture, local knowledge, and the peacemaking that local people perform each day as they live within conflicts. Political scientist Severine Autesserre presents practitioner insights as "surprising" and "new" approaches in the political science community (Autesserre 2021a; 2021b). Alongside scholarpractitioners, Roger Mac Ginty has been a leader in this "turn to the local" in the scholarship of conflict resolution (Mac Ginty 2008) and has detailed it in his work with Oliver Richmond (Mac Ginty and Richmond 2013). Mac Ginty describes how he witnessed his mother navigate peacemaking every day while raising him in Northern Ireland during the Troubles, getting him safely to and from school while living in a conflict zone (Mac Ginty 2019). Mac Ginty's work on "everyday peace" resonates with the people-centered approach to peacemaking: People make peace every day while living in conflict contexts, and this kind of everyday peace practice is a form of power (Mac Ginty 2019). Working with Mac Ginty, and extending this insight, Pamina Firchow has worked with locally developed indicators of peace to more appropriately evaluate conflict resolution efforts (Firchow 2018). Firchow also highlights that "World Peace is Local Peace," given that the majority of wars are not inter-state, and thus more of our peacemaking efforts must engage local peacemakers (Firchow 2020).

Culturally and locally attuned approaches to peacemaking, in short, combine the strengths of locals with cultural competence and the strengths of outsiders with fresh perspectives. Culture matters in peacemaking, local agency is critical, and outsiders can also play useful roles. In 1996, Grainne Kelly and I studied the mediation of parades disputes in Northern Ireland (Kelly and Nan 1998). These were disputes that arose yearly during the summer when loyalist Protestant residents with British allegiances celebrated their heritage and history by marching specific routes through some towns, and Catholic residents protested marches through Catholic neighborhoods in those towns. Grainne had lived her entire life in Northern Ireland, and I brought questions from afar. Together, as a team, we wove Kelly's long-term insider knowledge of the parades dispute context with my outsider questions and comparisons. A Northern Irish peacemaker I met with that summer told me that outsiders such as myself could be helpful by asking questions, listening to the experiences of local peacemakers, encouraging local peacemakers to 
reflect on their context and their efforts, and telling stories of what others have done in other places, thus possibly germinating new ideas for Northern Irish peacemakers.

Returning to Moire Dugan's nested model, discussed in Chapter 5, we see that conflicts are both local and global, or systemic, to use Dugan's terminology (Dugan 1996), and people are key actors at each of these levels in peace-centered peacemaking. Both the local and the global can be a focus for peacemaking, and neither can proceed very far without the other moving toward peace as well. People who form local zones of peace (Nan and Mitchell 1997) can promote peace within discrete communities, but must also engage with the broader national and global forces that affect those communities as well. Likewise, international peace agreements signed in capital cities may formally establish peace but are not meaningful for the people who still live insecurely within their own communities many miles away, where the peace has not been fully implemented. In postwar peacemaking, too, both local and international roles are essential for making a peace that is, likewise, both local and international (Allen 2017).

As peacemaking practice has developed over time, the roles of outsiders and insiders and those with connections in both have evolved and developed (Allen 2020). From an initial model of peacemaking practiced largely by impartial third parties, the roles of locals have gotten more recognition, as we have just seen, and practice has shown that there are roles for those who simultaneously hold both a local and international perspective. It is not uncommon for people in the diaspora who have left a conflict zone to engage in their home conflict area as peacemakers, drawing both on their local knowledge and their international platform. Philip Gamaghelyan, a United States citizen peacemaker and professor at the University of San Diego's Joan B. Kroc School of Peace Studies, as well as a co-director of Imagine Center for Conflict Transformation, once told me that he is sometimes seen as too American by people in Armenia where he grew up, so he is not fully an insider; but in Azerbaijan, he is also seen as too close to the Armenian side. People embedded in the conflict don't and can't easily label Gamaghelyan's role as fully insider or fully outsider. This liminal status brings strengths that come from his language and cultural background in one area of the conflict as well as from his connections in the United States and his fluent English that appeals to donors who are ready to support peacemaking and give him a platform to communicate conflict resolution possibilities to a large western audience.

To better analyze the roles of insiders and outsiders in the GeorgianSouth Ossetian peacemaking process, I summarize the strengths of each in Table 6.1 (Allen 2020, 80). The table presents insider-partial strengths, referring to Georgians and South Ossetians who are local coordinators of that peacemaking process, and, outsider-impartial strengths, referring to roles that we as external conveners played in the Point of View and Cost of Conflict processes. 
Table 6.1 Complementary Strengths of Insiders and Outsiders in Convening Georgian-South Ossetian Dialogues. (Reproduced with permission of Brill. Originally appeared on page 80 in Allen, Susan H. 2020. "Evolving Best Practices: Engaging the Strengths of Both External and Local Peacebuilders in Track Two Dialogues through Local Ownership." International Negotiation 26 (1): 67-84. 10.1163/15718069-BJA10006).

\begin{tabular}{ll}
\hline $\begin{array}{l}\text { Strengths of Insider-Partials } \\
\text { Serving as Local Coordinators }\end{array}$ & $\begin{array}{l}\text { Strengths of Outsider-Impartials Serving as } \\
\text { External Conveners }\end{array}$ \\
\hline $\begin{array}{l}\text { Local knowledge and cultural } \\
\text { insights }\end{array}$ & Comparative knowledge of other conflicts \\
$\begin{array}{l}\text { Fluency in Georgian/Ossetian and } \\
\text { Russian }\end{array}$ & $\begin{array}{c}\text { Fluency in English for proposal writing and } \\
\text { reporting to donors and familiarity with } \\
\text { this skill }\end{array}$ \\
Long-term (life-long) commitment & $\begin{array}{l}\text { Umbrella under which local peacebuilders } \\
\text { can safely meet }\end{array}$ \\
$\begin{array}{l}\text { Local reputation and contacts } \\
\text { Transfer of ideas to local }\end{array}$ & $\begin{array}{l}\text { Transfer of ideas to international actors and } \\
\text { to local leadership, when asked to do so }\end{array}$ \\
$\begin{array}{c}\text { Detailed local input on } \\
\text { substantive agenda }\end{array}$ & $\begin{array}{l}\text { Input on the agenda from an impartial } \\
\text { outsider }\end{array}$ \\
Knowledge of specific potential & Process training from other Track Two \\
participants & contexts \\
Partiality and passion for home & Impartiality and commitment to process \\
community & Facilitation experience \\
Facilitation experience & Logistical and event planning expertise
\end{tabular}

One of these outsiders' strengths is logistical and event planning expertise, which surprised me as I reflected on the process and compiled this table. We speak so much as peacemaking practitioners about sensitive conflict issues when we develop an agenda, invite participants to a discussion, and follow up, but we rarely highlight the logistical issues. And yet these logistics matter a great deal. Peacemaking is better when the venue is conducive to conversation, both in the formal sessions and in the informal times of meals, coffee breaks, walks, or perhaps a shared cultural experience. For example, when the Georgian-South Ossetian dialogue met at Point of View near Washington, the group went out one evening to hear jazz music together. Some of the Georgian-South Ossetian dialogues in Istanbul included an evening cruise on the Bosphorus, with dinner and Turkish music. This evening uniquely brought the group together, sharing music, food, and personal conversation in the cozy space of a boat. The Georgian and South Ossetian Point of View process once met in Yerevan for an evening tour of the cognac factory, which included tastings of different cognac vintages and viewing a barrel of cognac that has been labeled as "peace cognac" and will be opened only when Armenia and Azerbaijan achieve peace.

Insider local peacemakers have sometimes worked with minimal, if any, external support in their peacemaking. Often these experiences of entirely 
local peacemaking may remain unknown to outsiders. However, George Wachira, a Kenyan peacemaker who completed a masters at the University of Notre Dame in 1991 and in 2009 served as a visiting fellow at its Kroc Institute, documented his experience alongside four other Kenyans as he launched Concerned Citizens for Peace (CCP), a group that mobilized prominent Kenyans to call for peace, organized the local Nairobi Peace Forum and District Peace Committees, and contributed vitally in 2008 to ending post-election violence in Kenya (Wachira, Arendshorst, and Charles 2010). The CCP worked locally in many ways with Kenyans, and also contributed ideas to the Kofi Annan-led official mediations.

Other organizations have further elevated the voices and experiences of local peacemakers. Peace Direct provides multiple forms of support to local peacemakers in developing countries worldwide and highlights the roles of locals in addressing violence in their home communities. The Purdue Peace Project also supports locals who want to prevent violence in their home communities. Among other initiatives, Purdue reported on the International Peace and Prosperity Project to prevent election-related violence in Guinnea-Bissau in 2004-2005. Much of the leadership of that initiative was provided by people who called Guinnea-Bissau home (Dutta et al. 2021).

While local and international partnerships can leverage the peacemaking strengths of each, the financing for peacemaking work often comes internationally and can very easily dominate decisions on the qualities and characteristics of peace work. I was once involved in an initiative that tried very hard to support local leadership and not allow the financing structure to dominate. A western-based donor gave an international, western-based NGO a substantial sum to support peacemaking between two neighboring countries. The western-based NGO engaged local peacemakers in each country as project coordinators, who led the overall strategy of the peacemaking. Those local coordinators decided to contract my services as an individual to facilitate several dialogues. Often when I facilitate, most of the work is before and after the dialogue, with agenda planning, participant preparation, and follow-up on next steps. In this case, however, my role was only to implement the agenda they themselves had designed, and simply move the conversation along on the specified topics. As we worked together over several dialogues, having established that the local coordinators were truly driving the substantive agenda development, the coordinators began to consult with me on how to plan the flow of the agenda topics, the order of discussions, and ways to structure particular sessions. While the funding had come from a western donor, and the administration of the financing was handled by a western NGO, I was impressed that most of the substantive decisions were made by local peacemakers in the coordinating group. Still, funding did govern some decisions; for example, it imposed limits on the length of the meetings and the number of people who could participate with funded hotel rooms and meals, and that funding dynamic, which subtly shaped the process, was not fully avoided. 
Partnerships between international and local peacemakers can shift over time and assume various new forms. My experience as a facilitator who reported to local coordinators contrasts with my experience at the start of the Point of View process with Georgians and South Ossetians. At the first meeting, the internationals facilitated - Paula Garb, Kate Romanova, Lara Olson, and myself. After several dialogue meetings, the Georgian and South Ossetian coordinators increasingly took on more responsibility and began facilitating substantial portions of the meetings themselves. We planned the agenda collaboratively, working for consensus on all the substantive points. I sometimes joked that the George Mason University team had become travel agents - we arranged the travel and the meeting venue and looked to local coordinators to lead the peacemaking. The Point of View process shifted project leadership, as the university team decreased its convener and facilitator roles and the local leadership increased its roles in planning, convening, and facilitating.

This transition in responsibilities was not always smooth. We once had a miscommunication in our coordinating team about who would meet with a Georgian participant who would be joining the dialogue for the first time. She was a former politician who had had some experience with the Track One discussions. She had stepped down from government service and joined an NGO alongside a colleague who had previously participated in the dialogue. Her colleague recommended her, and one of the Georgian coordinators reached out to speak with her. I had understood that they had a wide-ranging discussion about the dialogue process, but the Georgian coordinator and the new participant actually only discussed a presentation we were asking her to make and the logistics of the meeting: where to meet to travel there, when the return trip was planned, and perhaps what hotel we'd be staying in. Neither the Georgian coordinator nor I - nor for that matter the colleague at the NGO with previous dialogue experience - briefed her on the tone of the Point of View discussions.

These discussions had developed over time into warm, personable conversations. Participants would disagree vociferously on political issues, but speak kindly to each other as individuals. In the past, I had briefed previous new participants in person, when possible. One former Georgian government official spoke with me before he came to the dialogue for the first time, and he asked specifically about the tone of the conversations. I described them as warm and friendly in a personal way, even though political differences ran deep. When he arrived at the dialogue, I noted that he spoke with the South Ossetian participants with apparently genuine respect and openness - getting to know them on a personal level and sharing greetings with colleagues they knew in common. He peeled oranges for some of the South Ossetian women during a break from a dialogue. They traded looks and accepted his gesture, eating the oranges and joking appreciatively about his attentiveness. Later that day, the conversations turned to issues on which he was well briefed, and he began to speak in his more professional tone about 
specific details of the ceasefire line monitoring process. He and the South Ossetians engaged on the substantive issues constructively, sharing ideas for how to improve everyday existence for those who lived very close to the ceasefire line on either side.

At the next Point of View dialogue, that orange-peeling Georgian couldn't attend and recommended his colleague, the former Georgian government official who, owing to miscommunication on the coordinating team, arrived without having been briefed on the tone of the Point of View dialogues. The Georgian participants arrived late at night, and I greeted them briefly as they checked into the hotel. I saw the new Georgian participant again at breakfast and said hello, reminding her that her presentation that morning should be ten minutes and open the conversation on an area of her expertise. She assured me that she was prepared.

She certainly was prepared - but not for a Point of View dialogue. Her speech was something more appropriate for a public setting where the goal was to demonstrate her patriotism to her home community, regardless of how offensive her opponents found her presentation. She began by expressing her gratitude for the opportunity to meet with her "fellow citizens," which immediately emphasized her partisan view of the South Ossetians as Georgian citizens. She spoke in Russian and used the Russian phrase for "fellow citizens," repeating the phrase multiple times as she outlined areas for discussion. The rest of her opening comments were unremarkable but that one phrase, repeated with emphasis, repelled the South Ossetian participants. As one told me later, it didn't matter how reasonable a few of her ideas were, because those words had made it impossible to truly listen to her.

At the coffee break, I spoke privately with her and apologized for not having briefed her about the usual tone of Point of View dialogues, in which participants try to speak honestly without offending each other. I explained the negative impact of that phrase on participants and asked her to consider ways to build bridges with the South Ossetians. I suggested, for example, that simply expressing gratitude for the chance to meet with "colleagues" or "people from Tskhinvali" or using each participants' name would have avoided the offense. I told her that South Ossetians had quickly shared with me that they interpreted the phrase "fellow citizens" as an attempt to underscore political differences and highlight how she saw them politically, but they wanted to be seen as people.

That evening, I saw her sitting with a group of South Ossetians who had gathered to sip wine. They were speaking about family. She asked about their families and told stories about her children, and the conversation was warm.

On the last day of the dialogue, she asked for a few moments to address the group. She apologized for not choosing her words carefully on the first day, and she thanked everyone for the warm welcome and the opportunity to learn so much from, especially, her new South Ossetian friends. She teared up as she shared that she had never thought such a personal conversation would be possible in the midst of the conflict. What had started 
out as a disaster - our failure to properly brief her on the dialogue before she arrived - turned into a story of dramatic transformation in attitude.

When I was in college, studying peace and conflict resolution, I collected several peace-related bumper stickers. One of them - and perhaps the most familiar - read, "Think Globally, Act Locally." I pinned that bumper sticker on my dormitory room bulletin board. It reminded me of connections between my daily actions and their potential larger ramifications. At the same time, I was taking a course in Tibetan Buddhism, so I also thought of the observations taught there of the potential ripples of impact caused by seemingly minor actions. Complexity Theory was also emerging as I studied in the late 1980s, so I thought also of the now-familiar example of a butterfly's wings fluttering in one place that causes very small changes that in turn unpredictably create a storm sometime later far away (Gleick 1987). I came of age surrounded by reminders both that individuals can make a difference and that the impact of specific actions cannot be predicted.

These formative concepts have stayed with me as I have studied further and the field of conflict resolution has grown to formally consider conflicts as "complex adaptive systems," meaning that small seemingly insignificant changes can reverberate into major shifts (Coleman, Liebovitch, and Fisher 2019). I now see that seemingly small, individual gestures of peacemaking have the potential to reverberate unpredictably into larger peacemaking effects in the complex adaptive systems that constitute both conflictual and peaceful social relations. How do we "do" peacemaking in the midst of such uncertainty? As practitioners, we can be guided by hard evidence of what generally works, and yet we cannot be sure with any one intervention how it will develop and its ultimate impact. We try to do what we can to make peace more likely, taking actions that we perceive to have potential, learning from the research and experience that has built the body of knowledge at the heart of the conflict resolution field, and drawing on our knowledge of the specific contexts where we work. The insights that guide peacemaking come from both the social science literature that offers evidence of what has worked in what sorts of situations and what tends to make peace more likely under what conditions (Druckman 2005); an understanding of the particular conflict cultural context (Avruch 1998); and the practitioner's "art and soul" of building peace (Lederach 2005); that is the moral imagination by which the practitioner is rooted in today's realities and also able to envision their desired future.

Just one individual, for example, might make a conciliatory gesture, but that action may have a larger impact. Gestures of Conciliation (Mitchell 2000) by Christopher Mitchell examines numerous efforts to deescalate conflicts and build trust with adversaries, including President Sadat's visit to Israel in 1977, the British Government's initiation of contacts with Sinn Fein in 1990, and former President Jimmy Carter's visit to North Korea in 1996. Based on his review Mitchell (p.118) describes and generalizes characteristics likely to increase the effectiveness of conciliatory gestures: "1. Magnitude of 
the change represented by the initiative; 2. Articulation of the initiative with the values, culture and history of the target; 3 . Transparency of the initiative so that performance can easily be monitored by the target; 4 . Unconditionality of the initiative, in that performance, does not depend on commitments or actions by the target; 5 . Voluntariness of the initiative, in that it is not seen as a reluctant move, wrung from the initiator by prior coercion." Despite this sound guidance, no one planning a conciliatory gesture can be certain that their own action will have the desired impact. Conflict systems are not entirely predictable. Conflicts involve multiple layers and are usually complex and full of uncertainties.

If the bumper sticker "Think Globally, Act Locally" reminds us succinctly of local-global connectivity, then Maire Dugan's "A Nested Theory of Conflict" (Dugan 1996) reminds us of the dense and unpredictable nature of the connections between conflicts in their global and local dimensions. As described in Chapter 4 Dugan (p. 15) considers four types of interrelated conflict: "issue-specific, relational, structural-subsystem, [and] structuralsystem." In Dugan's model, issue-specific conflicts are nested within relational conflicts, which are nested within structural-subsystem conflicts, and these are nested within structural-system conflicts. To recall, Dugan created this model when she was faced with a conflict that presented initially as one between two groups of boys at school, with specific issues and relational tensions, but given that one of the issues was that a White boy had a Confederate flag on his jacket, and the tensions were between a group of Black boys and White boys, the surrounding racist system was strongly implicated in the conflict, too, both within the subsystem of the school and within the surrounding social system.

Dugan's nested model of conflict is useful for the Georgian-South Ossetian experience. Georgians and South Ossetians today disagree on a myriad of issues. Consider, for example, the trash that in the postwar years began accumulating in the irrigation channel flowing from Tskhinvali across the ceasefire line to villages on the Georgian side of the dividing line. The issue-specific conflict here is trash in the irrigation channel, which both pollutes irrigation water and blocks its flow. The irrigation channel flows from the South Ossetian-controlled territory downstream to the Georgiancontrolled territory and then crosses the ceasefire line several more times. There are relational elements that shape the issue, as the two communities have been separated physically since the August 2008 war. People on the Georgian side do not know who to approach on the South Ossetian side to stop the trash accumulation in the irrigation channel. This lack of direct communication was in turn embedded in the structural subsystem of overall lack of communication across the ceasefire line in the postwar standoff. At this time official representatives of each side and Russia only communicated formally through the Geneva International Discussions process, including the related Ergneti Incident Prevention and Response Mechanism. And all of these elements were embedded in Russian-Western tensions, with Russia 
supporting South Ossetia and the West supporting Georgia. The issue of trash in that context was not just about trash, but, rather, was a manifestation of each of these systems of conflict.

What can local action look like in these circumstances? It can feel daunting to take on an issue of trash when it is also an issue of lack of communication in a formal Geneva process, and also part of overall global tensions. But, in the Point of View process, such issues were addressed. A Georgian from a village that was affected by the trash in the irrigation channel raised a question for South Ossetians participating in the dialogue. Did they have any ideas about who was putting trash in the irrigation channel and what could be done to stop it? The South Ossetians took the question seriously, even though they did not yet have an answer. One of them promised to go home and try to find out. Sure enough, she followed the irrigation channel to a place near the ceasefire line where an apartment building stood by the channel. She asked people there if they had any ideas, and they did. They had been living without regular trash service for several months and had taken to dumping their trash into the irrigation channel to be carried away by the water. Point of View participants promised to help them restore regular trash service for their community, returned to senior leaders in Tskhinval(i), and within a week the trash service resumed. At the next Point of View meeting, the Georgian participant commented that the irrigation channel seemed cleaner. In focusing on that one specific issue, it was effectively addressed. The challenging systemic relationships remained, but at least the trash was no longer being thrown into the irrigation channel.

Global and local contexts, in relation to each other, shape peacemaking. For over a decade contextual factors that shaped the Georgian-South Ossetian peacemaking process were as varied as the deteriorating Russian relationship with the West, the change in government in Georgia, the nearby Sochi Olympics, the coronavirus pandemic, and renewed fighting between Armenia and Azerbaijan over the disputed region of Nagorno Karabakh. Here we look at contextual factors that changed or emerged during the peacemaking process and how these factors affected the peacemaking process in the Georgian-South Ossetian context, and in other cases. As they contended with these factors the Georgian-South Ossetian peacemaking team demonstrated local leadership in its decision-making. This section examines the impact of these global shifts and local political developments on the peacemaking process, and deliberately maintains the focus on peacemaking. So many other works emphasize geopolitical and local political developments rather than peacemaking. And if we consider these contexts in relation to peacemaking, specifically, perseverance and working within the realm of the possible emerge as strong and persistent themes and lessons.

In the 2012 parliamentary elections, the Saakashvili affiliated United National Movement ceded power to the Georgian Dream coalition. This was a shift away from the rule of Mikheil Saakashvili, who most South Ossetians blamed personally for the August 2008 war. In televised remarks 
Saakashvili had reassured South Ossetians on the night of 7 August, telling them that they could go to sleep peacefully in Tskhinvali - and then the Georgian military bombed the city overnight. Saakashvili's loss was significant for the South Ossetians, as the man who had tried to kill them was voted out of power.

Georgian Dream's primary financial backer, billionaire Bidzina Ivanishvili, became Prime Minister. He appointed Paata Zakareishvili as Minister for Reintegration, continuing the name of the Ministry that Saakashvili's administration had used. As he contemplated taking the position the new Minister planned to change the name of the ministry, and in 2014 it was renamed the State Ministry for Reconciliation and Civic Equality. Included in this mandate was not only reconciliation with the Abkhaz and South Ossetians but also engagement with all minorities in Georgia, focusing on minority rights.

As detailed in Chapter Four, Paata Zakareishvili was a longtime coordinator of the Georgian-South Ossetian Point of View process. As an NGO leader, he had participated in many meetings with people who presented themselves as official representatives of South Ossetia. The shift in Georgian politics that brought Zakareishvili to the Ministry position also led to a decrease in official participation from the South Ossetian side. The South Ossetians who had formerly participated explained that they could not duplicate the Geneva International Discussions by meeting with senior officials from both sides in an informal setting. They had been eager to participate with lower-level Georgian counterparts, but when Zakareishvili became a Minister they declined to participate. Individual South Ossetians who did not hold official positions, however, continued to participate.

Zakareishvili and the Georgian Dream coalition shifted the Georgian approach to the conflicts. On 7 March 2013, at Zakareishvili's initiative, the Georgian Parliament passed a resolution clarifying that Georgia would not use force to attempt to achieve its goals with Abkhaz or South Ossetians. (Zakareishvili 2021, 16). Zakareishvili also decreased the "hate-based rhetoric" (p. 17) from the Georgian government directed at Abkhaz or South Ossetians. And, building on discussions from the Point of View process, Zakareishvili pursued the release of Abkhaz, South Ossetian, and Georgian prisoners held across the ceasefire lines.

Zakareishvili also clarified Georgian government policy to support participation in bilateral informal dialogues and explained the rationale for participating in these meetings:

Participants have the possibilities to: determine their own strategy and tactical steps by studying and considering the positions and interests of the opposing party; clarify each other's views on various issues through a dialogue and, there- fore, be ready for future formal or informal meetings; test or introduce with one another new suggestions or ideas. (Zakareishvili 2021, 20) 
These shifts in the Georgian approach to the conflicts opened space for South Ossetian engagement. But, instead, South Ossetian authorities retreated from the Point of View process. They no longer allowed any officials from South Ossetia to participate. This prompted discussions in the Point of View process that focused less on tentative agreements to go home and attempt to implement and more on consideration of ideas to take home and then discuss with leadership. In other words, Point of View shifted from directly influencing the South Ossetian side of the official Geneva International Discussions to offering indirect guidance. But throughout the political shifts, the peacemaking persevered and adapted to political context.

As Russia prepared to host the Olympics in Sochi in February 2014, it redoubled security in the area surrounding Sochi. Potentially, fighting could erupt around several places in the vicinity of Sochi. Abkhazia is just a few miles away from Sochi; South Ossetia is only a day's drive away; and other North Caucasus regions are not much farther. By the standards of Russia's expansive geography, these potential hot spots were in Sochi's neighborhood. South Ossetians in the Point of View process explained to me that Russian security services were trying to suppress any dissent and monitoring travel in the region. Thus, South Ossetian participants in the Point of View process felt that they had to be very careful not to be seen as dissenters or as opposition. Their participation in the Point of View dialogues had to be clearly situated as in no way whatsoever a threat to the Olympics. So we took a lower profile with our work and did not meet immediately before or during the Olympic games. We customized the peacemaking to fit within the parameters and constraints of the possible imposed by the Sochi Olympics.

In the years immediately after the August 2008 war, funding increased for peacemaking and peacebuilding related to the Georgian-Abkhaz, GeorgianSouth Ossetian, and Georgian-Russian conflicts. Then, after the conclusion of the Olympic games, war broke out in Ukraine in April 2014, and funding priorities shifted. Many locals and internationals working on South Caucasus area conflicts observed that the bulk of the funding from western countries to support peacemaking and peacebuilding shifted to Ukraine in 2014.

With this international shift, the Georgian-South Ossetian Point of View Process adapted to the leaner funding environment. No longer could we afford an external evaluator working over two years to provide feedback and help us improve the initiative. No longer could we hold larger meetings with close to thirty people. We scaled back expenses in order to continue meeting. The process shifted to smaller meetings of sometimes only three or four people from each side.

Despite lower levels of available funds we were committed to persevering with our meetings. We reasoned that ongoing, unofficial contact was essential to prevent an escalation that might lead to renewed war. We also thought that if we were to take a break for a year or two and then try to start meeting again, it would be harder to start a new process than to revive and re-energize the momentum after a period of ongoing, unofficial engagement. 
In February 2020, the Georgian and South Ossetian coordinators of the Value of Dialogue process met in Yerevan, just as the COVID pandemic was beginning. While we were meeting in Yerevan, the media announced confirmed cases of COVID-19 in Armenia. No one wore masks to get there or during the meeting, and we ate as usual in the hotel and a nearby restaurant. As we met, we discussed the new disease and mulled that travel might become difficult for a few months and that we likely would not be able to meet until the fall of 2020.

Prior to the meeting in Yerevan, I had purchased surgical masks, thinking I would use them later if the pandemic spread, so I passed out individually wrapped surgical masks to all of the participants as we prepared to leave the meeting, and then the Georgians and I donned masks as we stood in line for temperature checks and crossed the border from Armenia into Georgia.

A month later, the Fulbright program sent me home early from Tbilisi. I donned a mask and added to my suitcase a few rolls of Tbilisi-purchased toilet paper because I'd heard from a friend in Washington that the US was experiencing a toilet paper shortage. After a scramble for departing tickets, I left Georgia, where only isolated COVID cases had been reported, and traveled to New York, at the time the epicenter of the raging US COVID crisis. The State Department and Fulbright program had rightly predicted that travel would become difficult in the coming weeks.

Meanwhile, South Ossetia closed its borders, even with Russia, and Georgia went into lockdown as cases of COVID surfaced there. We all checked in with each other every week or so. In Tbilisi, COVID precautions closed public transportation and relegated taxi or Bolt passengers to the back seat. North Ossetia and Russia reported COVID cases. In South Ossetia, trucks arrived from Russia along with drivers. South Ossetians felt fortunate, as no cases were reported there.

This wouldn't last. Eventually, South Ossetia also reported COVID cases and then COVID deaths, and cases rose in Tbilisi and Washington alike. Our conversations shifted from peacemaking to checking in on each other about COVID precautions and safety in our communities. With every conversation, we at least confirmed that we were still alive. We continued to work on Value of Dialogue, recruiting authors to prepare papers for a successively postponed symposium on the Value of Dialogue in the Georgian-South Ossetian context. But, all of us were primarily focused on survival. Self-imposed publication deadlines passed, our donor was understanding, and we worked at a snail's pace.

Still, throughout the pandemic, we continued meeting as the core team.

It feels vital to continue our relationships and peacemaking, even if (or especially if) we do not see prospects for major political breakthroughs in the near future. By maintaining ties across the ceasefire line, we are functioning as a bridge, ready to engage deeply when the political will arises for potential agreements, and ready to act quickly should tensions escalate. We are ready to put out a fire, should one develop. 
The Fall 2020 outbreak of active war between Armenia and Azerbaijan over the disputed region of Nagorno Karabakh is another contextual factor that shaped the Georgian-South Ossetian discussions in several ways. First, the Georgians and South Ossetians and all of us involved in peacemaking in the region were sad to think of friends and colleagues in the region who were suffering in the war. Some knew people who died. We commiserated with each other as the tragedy unfolded. We sought ways to be helpful as best we could. Several met with Armenian and Azeri peacemakers to see if anything might alleviate the suffering. The retrieval of corpses from each side of the battle lines seemed a meaningful issue that both sides could agree on. The Armenians and Azeris took home that idea and worked with their leadership to try to bring about an agreement to return corpses across the battle lines. A week later, that humanitarian gesture began.

Once the immediate crisis of active fighting subsided, the Georgian and South Ossetian peacemakers turned to making sense of what that war and its ceasefire meant for their world. The speed with which the war had escalated to all-out fighting unnerved them. Anxiety rose in the group about potential sparks in the region, considering the possibility of renewed fighting between Georgian and Abkhaz and South Ossetian and Russian troops. The war to the south disquieted the group, and we recommitted to keep our network connected and ready to respond should a crisis arise in the Georgian-South Ossetian context.

The fighting to the south also raised pragmatic concerns for our plans. We had considered Yerevan a potential site for a meeting of the coordinators when we could finally meet in person. But the fighting in September-November 2020 and ongoing political turmoil in Armenia have raised questions about this. At this writing, in mid-2021, the pandemic has kept us from meeting in person. We will reassess where to meet when that becomes possible.

Although these dynamics and contexts for peacemaking, both locally and globally, are somewhat idiosyncratic to region and conflict, network theory helps make larger sense of them (Nan 2008). The concept of society as a network (Castells 1996), in which we all are connected through strong and weak ties, has implications for conflict resolution generally and peacemaking specifically (Nan 2008). Peacemakers who bridge divides provide rare crosscutting ties between societies. With these bridges good communication can happen, new ideas can spread, and shifts toward peace can occur among groups that are otherwise separated. In this light, the decision of the Georgian and South Ossetian peacemakers to stay in touch by continuing to meet online throughout the pandemic makes sense: they are continuing to build traverses between their otherwise very separate societies.

The peacemaking community in a specific conflict region can usefully be envisioned as a network. These networks expand and contract, as do other networks. When I worked with Paula Garb on Georgian-Abkhaz peacemaking, the Georgian and Abkhaz peacemakers articulated a goal of expanding the circle (network) of those engaged in peacemaking but doing so 
gradually enough to maintain and preserve the constructive tone of the meetings. The community of people who were practicing peacemaking in the Georgian-Abkhaz context formed a coordination network for peacemaking initiatives to maximize collective impact (Nan and Garb 2006). This coordination network brought together many of the internationals focused on Georgian-Abkhaz peacemaking, along with some of the most active Abkhaz and Georgians, too. The coordination network allowed all participants to align their work based on shared analyses of appropriate strategy as circumstances changed and developed. For example, at a meeting Paula Garb convened in Sochi, many internationals, as well as Abkhaz and Georgians, agreed on the importance of focusing attention on building internet capacity in Abkhazia in order to ease the peacemaking work. Once the internet service was expanded, thanks to actions by multiple individuals who participated in that meeting, other priorities emerged. Peacemaking efforts changed over time apace with changing contexts and peacemaker decisions. Likewise, networks expand and contract as their focus broadens and narrows according to context and choices (Nan 2008).

Networks develop over time. The Caucasus Forum was a very active network of civil society leaders from across the North and South Caucasus that enjoyed substantial support from International Alert from 1998-2004 (Ter-Gabrielyan 2012). Meetings that convene civil society activists from across the region allow for discussion of many of the region's conflicts and social trends. The Caucasus Forum network went quiet in 2004 after International Alert funding for in-person meetings ceased, but the email list that connected network members remained. From 2004 to 2008 there were only occasional messages to the Caucasus Forum email list. Then, when the August 2008 war broke out, the list suddenly activated as people exchanged messages, seeking links to friends who they feared might be suffering in the war. That network persisted, at least electronically, and although dormant or nearly so for some time was able to instantly support basic communication in a time of crisis. See Chapter 8 for further discussion of networks for peacemaking.

Returning to Dugan's nested model, we see local and global aspects of peacemaking in these examples as inextricably related layers of conflict. Peacemaking at the local level is shaped by and shapes global dynamics and vice versa.

One form of perseverance in peacemaking is ongoing adaptation to the realm of the possible. For example, when South Ossetian authorities decided they would no longer allow officials to participate in future Point of View discussions, we adapted and invited more unofficial participants from South Ossetia. When South Ossetian participants felt pressure from their leadership not to do any high-profile meetings with Georgians, we pivoted to smaller, low-key discussions without press releases or fanfare. And, after an avalanche of snow covered the entrance to the Roki tunnel, a key transit point for South Ossetians that connects South Ossetia to Russia, we waited 
in Yerevan three days while the snow was cleared, negotiated with the hotel to adjust the bookings, and met three days later than planned. In ways large and small - sometimes conceptual and sometimes practical - we adjust as needed to continue moving, however slowly, toward peace.

Such adaptation can be seen especially when peacemaking faces a restrictive environment that places more constraints on the space for peacemaking than usual. The next chapter turns to consider how peacemaking can continue in the face of substantial constraints.

\section{Note}

1 The same bumper sticker appears to be available currently at: https:// www.peaceproject.com/product/think-globally-act-locally-bumper-sticker-decalor-magnet/

\section{Works Cited}

Allen, Susan H. 2017. "Who Rebuilds? Local Roles in Rebuilding Shattered Societies." In Rethinking Humanitarian Intervention in the 21st Century, 2017, 267-286. Edinburgh: Edinburgh University Press.

Allen, Susan H. 2020. "Evolving Best Practices: Engaging the Strengths of Both External and Local Peacebuilders in Track Two Dialogues through Local Ownership.” International Negotiation 26 (1): 67-84. 10.1163/15718069-BJA10006.

Arai, Tatsushi. 2015. "Engaging Conflict History: Toward an Integrated Method of Conflict Resolution Dialogue and Capacity Building." Conflict Resolution Quarterly 32 (3): 277-298. 10.1002/crq.21113.

Arai, Tatsushi, Shihoko Goto, and Zheng Wang. 2013. Clash of National Identities: China, Japan, and the East China Sea Territorial Dispute. Washington, DC: Wilson Center.

Autesserre, Severine. 2021a. The Frontlines of Peace: An Insider's Guide to Changing the World. Oxford, UK: Oxford University Press.

Autesserre, Severine. 2021b. "Analysis | Negotiating Peace the Same Old Way Doesn't Work. Here's What Does." Washington Post, March 22, 2021, sec. Monkey Cage. https://www.washingtonpost.com/politics/2021/03/22/negotiatingpeace-same-old-way-doesnt-work-heres-what-does/.

Avruch, Kevin. 1998. Culture and Conflict Resolution. Washington, DC: United States Institute of Peace Press.

Castells, Manuel. 1996. The Rise of the Network Society. Information Age; v. 1. Malden, Mass: Blackwell Publishers.

Coleman, Peter T, Larry S Liebovitch, and Joshua Fisher. 2019. "Taking Complex Systems Seriously: Visualizing and Modeling the Dynamics of Sustainable Peace." Global Policy 10 (June): 84-92. 10.1111/1758-5899.12680.

Druckman, Daniel. 2005. Doing Research Methods of Inquiry for Conflict Analysis. Thousand Oaks, Calif.: SAGE.

Dugan, Maire A. 1996. "A Nested Theory of Conflict." A Leadership Journal: Women in Leadership- Sharing the Vision 1 (July): 9-20.

Dutta, Mohan, Stacey L Connaughton, Evan Hoffman, Agaptus Anaele, Christina Jones, and Angela Kachuyevski. 2021. "Purdue University Report on the 
International Peace and Prosperity Project in Gudinea-Bissau." Purdue Peace Project. https://cla.purdue.edu/ppp/documents/publications/Purdue.pdf.

Firchow, Pamina. 2018. Reclaiming Everyday Peace: Local Voices in Measurement and Evaluation after War. Cambridge, United Kingdom: Cambridge University Press.

Firchow, Pamina. 2020. "World Peace Is Local Peace." Ethics \& International Affairs 34 (1): 57-65. 10.1017/S0892679420000088.

Fisher, Ronald J. 1997. Interactive Conflict Resolution. 1st ed. Syracuse Studies on Peace and Conflict Resolution. Syracuse, N.Y: Syracuse University Press.

Gleick, James. 1987. Chaos: Making a New Science. New York, N.Y., U.S.A: Viking. Kelly, Grainne, and Susan Allen Nan. 1998. "Mediation in Practice in Northern Ireland: The INCORE Research Report." In Mediation in Practice: A Report of the Art of Mediation Project, edited by Grainne Kelly. Londonderry: INCORE. https://cain.ulster.ac.uk/issues/parade/kelly.jpg.

Kelman, Herbert C. 2000. "The Role of the Scholar-Practitioner in International Conflict Resolution.” International Studies Perspectives 1 (3): 273. 10.1111/1528-35 77.00027.

LeBaron, Michelle. 2003. Bridging Cultural Conflicts: A New Approach for a Changing World. 1st ed. San Francisco, CA: Jossey-Bass.

LeBaron, Michelle, and Venashri Pillay. 2006. Conflict across Cultures: A Unique Experience of Bridging Differences. Boston: Intercultural Press.

Lederach, John Paul. 1999. The Journey toward Reconciliation. Scottdale, Pa: Herald Press.

Lederach, John Paul. 2005. The Moral Imagination: The Art and Soul of Building Peace. New York: Oxford University Press, Oxford University Press, Incorporated. 10.1093/0195174542.001.0001.

Mac Ginty, Roger. 2008. "Indigenous Peace-Making Versus the Liberal Peace." Cooperation and Conflict 43 (2): 139-163. 10.1177/0010836708089080.

Mac Ginty, Roger. 2019. "Peace Power: The Concept and Practice of Everyday Peace." Presented at the Critical Conversations, Arlington, Virginia, November 12.

Mac Ginty, Roger, and Oliver P Richmond. 2013. "The Local Turn in Peace Building: A Critical Agenda for Peace.” Third World Quarterly 34 (5): 763-783. 10.1080/01436597.2013.800750.

Mitchell, CR 2000. Gestures of Conciliation: Factors Contributing to Successful Olive Branches. New York: St Martin's Press.

Mitchell, Christopher, and Michael Banks. 1996. Handbook of Conflict Resolution: The Analytical Problem Solving Approach. New York: Pinter.

Nan, Susan Allen. 2008. "Conflict Resolution in a Network Society." International Negotiation (Hague, Netherlands) 13 (1): 111-131. 10.1163/138234008X297995.

Nan, Susan Allen. 2011. "Consciousness in Culture-based Conflict and Conflict Resolution." Conflict Resolution Quarterly 28 (3): 239-262. 10.1002/crq.20022.

Nan, Susan Allen, and Paula Garb. 2006. "Negotiating in a Coordination Network of Citizen Peacebuilding Initiatives in the Georgian-Abkhaz Peace Process." International Negotiation (Hague, Netherlands) 11 (1): 7-35. 10.1163/157180606777835748.

Nan, Susan Allen, and Christopher Mitchell. 1997. "Generalizations and Practical Applications.” Peace Review 9 (2): 255-257. 10.1080/10402659708426060.

Richmond, Oliver P. 2011. "De-Romanticising the Local, de-Mystifying the International: Hybridity in Timor Leste and the Solomon Islands." The Pacific Review 24 (1): 115-136. 10.1080/09512748.2010.546873. 
Scott, J. C. 1990. Domination and the Arts of Resistance. New Haven: Yale University Press.

Ter-Gabrielyan, Gevorg. 2012. "The Experience of the Caucasus Forum: An Experiment in Holistic Peacebuilding." In Mediation and Dialogue in the South Caucasus: A Reflection on 15 Years of Conflict Transformation Initiatives. London: International Alert.

Wachira, George, Thomas Arendshorst, and Simon Charles. 2010. "Citizens in Action: Making Peace in the Post-Election Crisis in Kenya 2008." NPI-Africa. https://media.africaportal.org/documents/CITIZENS_IN_ACTION_Making_ Peace_.pdf.

Zakareishvili, Paata. 2021. Vision: Conflicts in Georgia 2012-2016. Tbilisi: FriedrichEbert-Stiftung. 


\section{Peacemakers Adapt}

How is it that people who are not officials can engage in peace work, without upsetting those who politically represent their home communities? This is a question anywhere, as states do not want unofficial people officially representing them. The United States has the Logan Act, which criminalizes any private citizen negotiating with a foreign government that has a dispute with the United States. The question becomes more urgent when the official structures look with suspicion on peace work, even those peace dialogues that stay away from official negotiation. That has become the case in South Ossetia, where over time the official attitude towards unofficial dialogues became more and more cautious.

Both Russian and South Ossetian security services are active in South Ossetia, and people harbor strong suspicions toward any western influence. Peacemaking dialogues are generally seen in South Ossetia as Westerninfluenced, particularly when they are funded by western organizations or western states, as most in this region are. South Ossetia passed what started as a "Law on Foreign Agents" but became a "Law on Foreign Partners." The South Ossetian Law on Foreign Partners is almost identical to the Russian Law on Foreign Agents. The name difference came about because several participants in the Georgian-South Ossetian Point of View process argued to South Ossetian parliamentarians that they were partners of George Mason University and not agents. They emphasized their partnership and agency in shaping the peacemaking process, rather than the narrow role of implementing others' plans that they felt the word "agent" implied. The same word "agent" in Russian (агент) also implies a spy. Despite the more tolerant and expansive name, the South Ossetian law requires any organization in South Ossetia that operates with foreign funding to register as a foreign partner and report on all of their activities. After the law was passed, several NGOs in South Ossetia dissolved, to avoid having to register as foreign "partners."

Despite these restrictions, South Ossetian peacemakers see roles for themselves. Having once engaged in Track One and a Half diplomacy, with officials coming from South Ossetia to unofficial meetings, they now focus only on Track Two diplomacy, being clear their activities are fully unofficial.

DOI: $10.4324 / 9781003189008-7$ 
They focus on contributing in ways that do not threaten the political leadership or the security services (such as the KGB or FSB). Focusing on humanitarian issues such as food, water, healthcare, the return of remains to families for burial, and efforts to find missing persons allows peacemakers to make contributions that de-escalate tensions but do not pose security risks within their community. These peacemakers are operating in the space that is available to them. They are pushing the boundaries of that space gently. Recall the metaphor of pushing the envelope without tearing it. The peacemakers are making contributions to improve life for those affected by the 2008 war. The following account of the three phases of the process show how peacemakers operated within the limits of the possible.

\section{Stages of the Georgian-South Ossetian Peacemaking Process}

There are three basic phases of the Georgian-South Ossetian peacemaking I have worked on since 2008. First, these unofficial peacemakers participated in the Point of View Process that started in the fall of 2008, just after the August 2008 war. Over time, the process shifted to become the Cost of Conflict process, and then the Value of Dialogue process, as the process adapted to changing circumstances. As the context changed, the core team made different process choices.

\section{Point of View}

At its first meeting, the Point of View process considered whether there was anything to talk about, and then the focus turned to how to address immediate humanitarian issues. Working on humanitarian issues, in turn, catalyzed other confidence-building measures, and considerations of how the unofficial peacemaking process could address both local and global issues.

To take on specific issues, the Point of View process expanded to include people with expertise on the selected issue at each meeting. For example, when we worked on how to achieve the functions of the Incident Prevention and Response Mechanism (IPRM), we involved the delegation leader to the IPRM from the South Ossetian side. When we explored how ambulances could cross the ceasefire line more quickly during medical emergencies, we included medical personnel from each side as well as participants in the IPRM. When we considered the release of prisoners, we invited a co-Chair of the Geneva International Discussions (GID), recognizing that the parties would want GID support for a final agreement. And, when we worked on repair of the Zonkari Dam, we invited OSCE advisors and engineers with knowledge of the technical issues involved in the repair.

The repair of the Zonkari Dam took several years and much perseverance, but it was a humanitarian effort that drew support from all involved. The gates in the dam that were designed to lift and allow for a controlled flow of water from the reservoir were stuck. Water was spilling uncontrolled into 
the overflow channel. Meanwhile, people fished in the dam by throwing grenades into the reservoir water to stun the fish and thus take home a large catch as the fish floated to the top of the water. Any errant grenade might have burst the aging concrete dam that held back a reservoir overfull and that surpassed engineers' estimates of its capacity. Projections estimated that, if the dam burst, a three-meter high tsunami-like flood would race downstream, demolishing Ossetian and Georgian villages alike and dissipating as a one-meter flood close to the Baku-Tbilisi-Ceyhan (BTC) crude oil pipeline. No one wanted to see such a catastrophe.

An engineer living in Tbilisi named Konstantin Predein played a key role. When the Georgian government could not find the plans for the dam in Soviet-era archives, Predein remembered the dam from the days when he had helped to build it fifty years earlier. He drew approximate diagrams of the dam's internal mechanisms, having crawled through the dam's tunnels as a young man during the construction period. South Ossetian officials accepted Predein's help as an engineer, inviting him to cross the ceasefire line to come consult on the dam's repair.

How did South Ossetians come to trust Predein? It may have helped that his last name was Lithuanian, thanks to his father's family background, but he considered himself Georgian, and South Ossetians involved told me that they accepted his engineering expertise simply because he was clearly an engineer who was not concerned with politics. Predein came to multiple Point of View meetings, drawing on napkins and flipcharts as he envisioned approaches to coaxing the dam's gates to lift, and allowing the water to flow out in a controlled manner, bringing the water level down to a safe level, and controlling the flow of irrigation water.

In his 80 s and otherwise retired, Predein was committed to seeing the dam repair through to completion. Frequently, he would call me by Skype to give me an update on the progress, as OSCE funding purchased much-needed heavy equipment to lift the gates for the first time in many years, and GID staff negotiated arrangements for the delivery of the equipment. One day, Predein called me by Skype and exclaimed with a huge grin, "The water is flowing! They did it! The water is in the irrigation channel, and that means they've lifted the gates!" He had received a call from a friend who saw water in the irrigation channel on the Georgian side of the ceasefire line, and Predein just had to share the news. I shared his joy at both the triumph of collaborative work and an end to the threat of a potentially catastrophic flood.

The repair of the dam led to further Point of View meetings that focused on cleaning the irrigation channel, regulating the water level in the irrigation channel, and sharing the water as it flowed back and forth across the ceasefire line between Ossetian, Georgian, and then again back to Ossetian villages. As in so many conflict areas across the globe, water does not respect ceasefire lines.

The core team leading the Point of View Process, including two Georgian and two South Ossetian peacemakers, regularly reflected on the process and 
gave feedback on the initiative and its changing context, and we adjusted our plans accordingly. These team planning sessions were intensive, often happening weekly on the internet. These long discussions were structured so that Georgian and South Ossetian peacemakers took maximum leadership of the process, bringing their insights based on living in their home communities and understanding many local nuances. While the team at George Mason University, myself, and other internationals assisted the Point of View process, Georgians and South Ossetians led the process (see Chapter 6).

Periodically, the larger group of participants at Point of View meetings also engaged in reflective practice. Every meeting included some evaluation on the final day and opportunities for input on future Point of View plans. Sometimes, that reflective practice was more intensive. In 2010, for example, we spent several hours on the first day of a Point of View meeting considering goals and making sense of the process' effects. We looked at the Reflecting on Peace Practice Matrix, a four-quadrant diagram (see Table 7.1, Reflecting on Peace Practice Matrix).

I presented the four quadrants and asked participants to consider where their work fit. After much discussion, we drew a diagram of the Point of View process as a catalytic workshop, mapped onto the four quadrants. Figure 7.1 below is the diagram the group created together in that fall 2010 workshop. It illustrates that the workshop involves both key people (leadership from one side) and more people (civil society members), so the workshop sits between these strategies. The workshop's immediate outputs, noted by the largest arrows, are new ideas and confidence-building measures. By design, the workshops created new ideas for confidence-building measures and also set in motion the implementation of some of those measures. To the extent that leadership participated in the workshops, there was some influence on leaders' ideas, too. Of course, other factors beyond the workshop also influenced them.

These new ideas increased support for confidence-building measuresagain, both with more people and with key people. Leaders' actions as influenced by workshop discussions led to supportive statements about confidencebuilding measures and multiple humanitarian initiatives, such as the provision of gas for heat to a region after the war, repair of the Zonkari dam, regulation of irrigation water, resumption of the Incident Prevention and Response Mechanism, and prisoner release. Together, participants emphasized the Point

Table 7.1 Reflecting on Peace Practice Matrix ("Reflecting on Peace Practice (RPP) Basics. A Resource Manual" 2016, p. 34)

\begin{tabular}{lll}
\hline & More People Strategies & Key People Strategies \\
\hline $\begin{array}{l}\text { Individual/Personal Change } \\
\text { Socio-Political Change }\end{array}$ & $\begin{array}{l}\text { Trauma healing } \\
\text { Mobilization of citizens' } \\
\text { groups }\end{array}$ & $\begin{array}{l}\text { Leadership dialogue } \\
\text { Negotiation of a peace } \\
\text { agreement }\end{array}$ \\
\hline
\end{tabular}




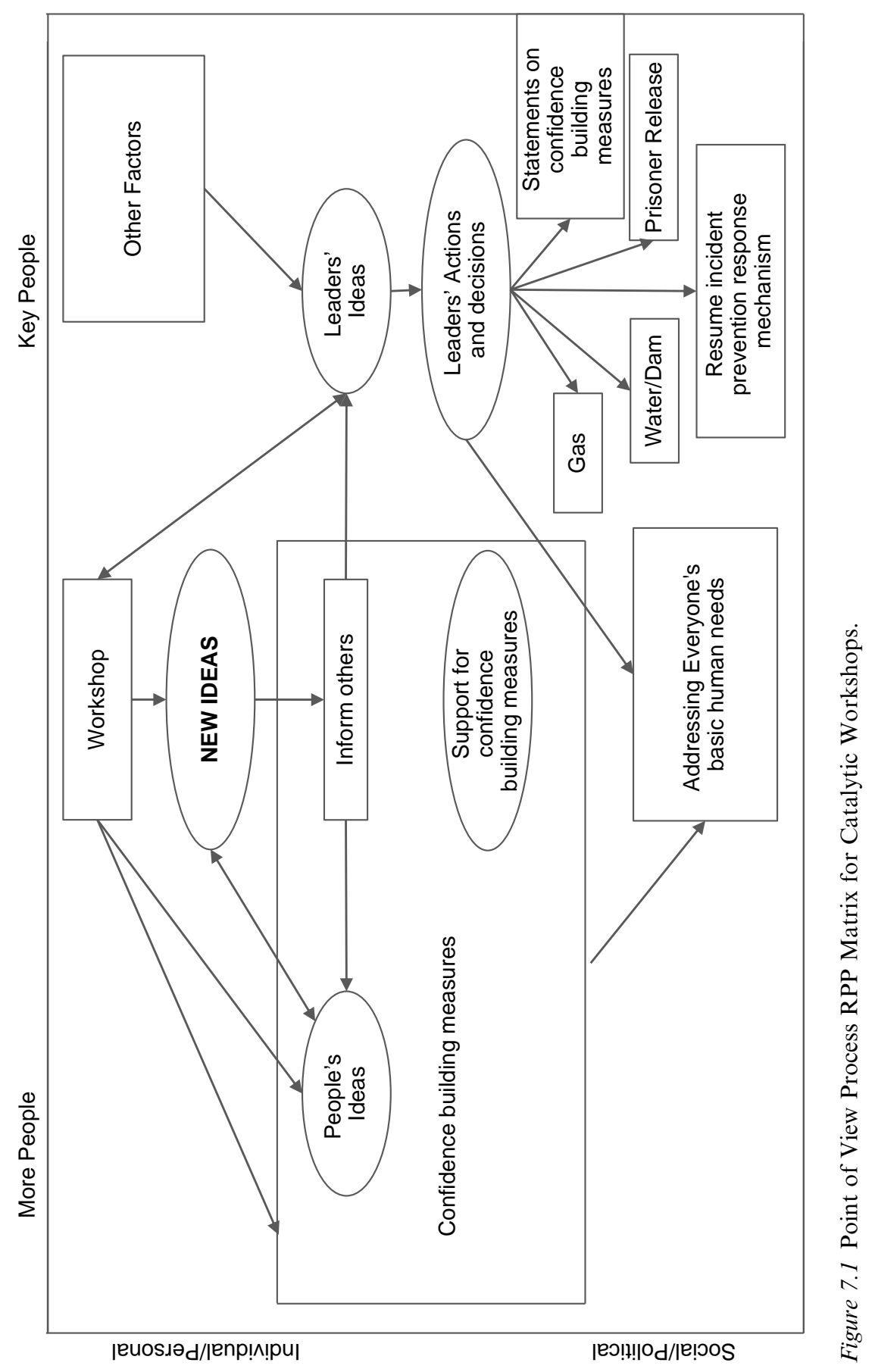


of View process' focus on humanitarian issues and addressed what they called basic human needs.

The Point of View process at the time of the 2010 reflection convened for a three-day agenda. Internationals working in the conflict area, who found it difficult to access South Ossetian views in any other format, were also invited to participate in part of the workshop. Ideas catalyzed at the Point of View dialogues could immediately be discussed with other internationals, who might support new confidence-building initiatives with mini-grants. All attendees at meetings participated in their personal capacity. We asked people to speak for themselves, and not to represent their officials. We emphasized that each of the participants would have insights from their own experience and that together we would develop a richer understanding as we listened to multiple perspectives.

By 2010, Georgians and South Ossetians were co-facilitating many of the workshop sessions. Usually, we began with updates on developments in context: Georgian-controlled areas, South Ossetian-controlled areas, and the international arena. Next, we moved to joint analysis of areas where new confidence-building measures might be possible. Finally, we turned to next steps planning - taking into account both the individual steps that participants might choose to take on their own, each working in their area of expertise, and also considering what the group would do together in the future.

Over time, the context of the POV meetings changed. One significant change was the election of the Georgian Dream coalition in 2012. Financed by billionaire Bidzina Ivanishvili, the coalition brought together six diverse political parties and successfully challenged the ruling United National Movement party led by Mikheil Saakashvili. As a result of these elections, one of the Georgian coordinators of the Point of View process, Paata Zakareishvili, became State Minister for Reintegration of Georgia. Paata quickly renamed his new office the Ministry for Reconciliation and Civic Equality (not Reintegration), and himself the State Minister for Reconciliation and Civic Equality. The name switch, significantly, indicated his emphasis on reconciliation. Rather than presuppose that reintegration (the re-absorption of Abkhazia and South Ossetia into Georgia proper) was the preferred outcome, reconciliation emphasized the development of respectful relationships.

It seemed that the POV dialogue meetings that had been attended by senior South Ossetian officials, including the Minister for Foreign Affairs, the Chair of the IPRM, and members of the South Ossetian team for the Geneva International Discussions, would suddenly now have a Georgian minister engaged. As Paata adjusted to his new position, he agreed to come for dinner and a personal visit with the POV dialogue group, but he did not stay as a full participant for the three-day meetings.

And then, suddenly, the senior South Ossetian officials explained that they would no longer be able to attend the Point of View meetings; only civil society members and academics would come from South Ossetia. The South 
Ossetians did not want to recreate a new Geneva International Discussions (GID) at Point of View - they explained their worry that having senior officials from both sides meeting in an informal environment would somehow replicate or replace the GID process.

Ironically, I could only meet with South Ossetian officials to discuss matters in Geneva. I could not travel to South Ossetia. I had once received an official invitation from the Minister of Foreign Affairs of South Ossetia and had applied for a multi-entry visa to Russia to allow me to travel through Russia to South Ossetia and then back into Russia. However, at this time, Russia had given me only a single-entry visa. This meant that I could go through Russia to South Ossetia, but then I would have no way to get out of South Ossetia, as I would not be allowed to enter Russia a second time. So, in October 2013, I flew to Geneva to meet with several people on the margins of the Geneva International Discussions. The South Ossetian officials met me warmly and expressed regret that they were no longer able to participate in the Point of View discussions. They wished me well in my continued work with civil society and academic participants.

The Point of View process continued, focusing on unofficial initiatives and catalyzing other confidence-building measures. Then, in 2015, several disinformation stories appeared, apparently written by Russian agents seeking to discredit the Point of View process. The process was framed as a well-funded US initiative to support Georgia's territorial integrity. Several other Westernfunded initiatives focused on the Georgian-Abkhaz relationship were also targeted by similar disinformation campaigns. We took this as a sign that our work was significant and worrisome enough to provoke action against us. Given our admiration for the other initiatives targeted at the same time, we decided it was, in some way, a sign of success. We even added this to our evaluation plans as an unexpected indicator of the initiative's influence. However, it was also a reason to abandon the Point of View process.

\section{Cost of Conflict}

The Cost of Conflict process grew out of the Point of View process. To mark a new approach to the Georgian-South Ossetian peacemaking process, the South Ossetians asked us to rename the process. We settled on the "Cost of Conflict," as we were working with Georgian and South Ossetian analysts to create a publication that presented Georgian, South Ossetian, and international views on the cost of the Georgian-South Ossetian conflict, encompassing institutional, economic, and human costs. Our South Ossetian partners assured us that they would not be endangered for participating as experts in their professional capacities in analytical and academic meetings and publications.

After preparing the Cost of Conflict publication (Alborova, Susan Allen, and Nino Kalandarishvili 2016a), we planned to present the articles in Vienna in April 2016. Alongside the analytical articles, we published a set of 
articles that presented personal stories of the cost of the conflict (Alborova, Susan Allen, and Nino Kalandarishvili 2016b). Partnering with the International Peace Institute in Vienna, we arranged to use a beautiful old palace in Vienna as the venue for the Cost of Conflict discussion, with translation equipment and professional interpreters in booths, to allow many diplomats and advisors associated with the OSCE to hear the presentations and discussions. The group preparing to travel from South Ossetia met with Kazbulat Tskhovrebov, the Foreign Minister, to prepare for their trip. He encouraged them to represent South Ossetia in Vienna and to raise the profile of South Ossetian perspectives internationally. However, the day before the South Ossetians were due to depart, President Leonid Tibilov called those working for the government to meet with him. Tibilov forbade government employees from traveling to the meeting. He argued that meeting with Georgians there would be against South Ossetian interests. These four of the planned group of ten stayed home. The others, who did not have government jobs, traveled to Vienna, presented their papers, and met with international diplomats who came to hear the discussion. These six South Ossetians and ten Georgians came to Vienna, due to the four last-minute cancellations caused by Tibilov. After the two-day conference that welcomed diplomats interested in the conflict and peacemaking process, we held a small dialogue meeting with only the Georgians and South Ossetians, planning for future areas of possible engagement together. A few days later, Kazbulat Tskhovrebov resigned as Foreign Minister, citing the President's refusal to allow representation of South Ossetia at the Cost of Conflict conference as one of his reasons.

The Cost of Conflict process aimed to preserve the space available for constructive conversation on problems shared by Georgians and South Ossetians. As that space diminished, with President Tibilov's further restrictions, we continued in the remaining available space. We subsequently pivoted to meeting in small groups with just the coordinators of the process - two or three Georgians and South Ossetians, each, to plan meetings that sought to evaluate what peacemaking would still be possible in this constrained space. These small meetings of civil society people did not provoke any crackdowns from South Ossetian authorities. While we made no revolutionary progress in the small meeting format, we felt that continuing the process was itself a triumph. We accomplished this continuity by working within the constraints rather than immediately trying to obliterate them. This is another example of pushing the envelope forward a tiny bit without tearing it. We continued movement towards peace, without provoking a backlash.

\section{Value of Dialogue}

We called the next stage of our meetings the Value of Dialogue. This name emerged out of several small meetings of the Georgian and South Ossetian coordinators to consider the possibilities, even within exigencies and 
restrictions. The South Ossetian partners, in particular, had emphasized that it would be safe for them to participate in expert analysis, particularly journalistic or academic initiatives. They could do qualitative but not quantitative research without raising concerns in their government. So, we began the Value of Dialogue process to focus after Cost of Conflict on the positive: what has been the value of dialogue in the Georgian-South Ossetian context?

This initiative was conceived before the Covid-19 pandemic was widely understood. The coordinators met in person in February 2020 in Yerevan, just as the first coronavirus cases were reported in Armenia. The group traveled home in masks, not knowing how long it would be before they could reconvene in person. Quickly, as lockdowns spread, it became clear that the Value of Dialogue group would not meet in summer 2020 as planned.

The work migrated online. The coordinators became editors of the planned publication. We met with authors online to discuss their drafts, and we sometimes met simply to chat, and to catch up on how we were all surviving the pandemic.

As our pace slowed down, I asked coordinators if they would like to celebrate the Old New Year together on Zoom. We had previously celebrated it together on January 13 in person, as we planned Point of View dialogue meetings to correspond to this holiday. This time, we circulated a Zoom link to old-timers - people who had been part of the Point of View Old New Year gatherings. We gathered online for an hour. We toasted to each other, future generations, past generations, peace, and love. One connected by Zoom in the midst of a party. Another joined an hour late as we were about to end the Zoom session, and we stayed online longer to visit with him. The virtual party did not touch on current conflict issues in any way. We simply celebrated that we are in each other's lives, alive, and striving to do good in this world. I felt grateful, as I joined that virtual gathering, to have developed friendships with many of the Georgian and South Ossetian core partners. While we have focused on Georgian-South Ossetian peacemaking, we have also supported each other through life changes over the year. When one participant lost her granddaughter to a sudden death, everyone rallied to support her as she reeled from her own loss and supported her daughter through the tragedy.

In the days that I was doing final revisions on this manuscript in July 2021, we lost one of the South Ossetian coordinators of the Cost of Conflict and the Value of Dialogue processes. Dina Alborova passed away after a brief battle with COVID. The full community of peacemakers in the region came together to try to make sense of the unintelligible loss and to mourn her passing. Those far away sent messages that were read at Dina's funeral in South Ossetia. Many gathered from around the world for an online memorial service for Dina that a Russian Orthodox priest in Washington DC led for Dina. Dina was so much more than a colleague to this community of peacemakers; she was a true friend. 
How do these deeply personal relationships, built through peacemaking processes over time, grow, and develop? The next chapter will consider the long-term nature of peacemaking, and the networks and communities that develop while peacemaking together.

\section{Works Cited}

Alborova, Dina, Susan Allen, and Nino Kalandarishvili, eds. 2016a. Cost of Conflict: Core Dimensions of the Georgian-South Ossetian Context. Fairfax, Virginia: George Mason University and the Alliance for Conflict Transformation.

Alborova, Dina, Susan Allen, and Nino Kalandarishvili, eds. 2016b. Cost of Conflict: Untold Stories, Georgian- South Ossetian Conflict in People's Lives. Fairfax, Virginia: George Mason University and the Alliance for Conflict Transformation.

"Reflecting on Peace Practice (RPP) Basics. A Resource Manual." 2016. CDA Collaborative Learning Projects. https://www.cdacollaborative.org/wp-content/ uploads/2017/01/Reflecting-on-Peace-Practice-RPP-Basics-A-Resource-Manual.pdf. 


\section{Both Individuals and Groups of People Make Peace}

A people-centered approach does not call for a focus only on individuals. Peacemaking requires both individuals and groups of people. Indeed, much peacemaking requires a "both... and..." approach. Both group A and group B usually have valid concerns.

Peacemaking engages the specificities of each conflict and commonalities of inter-group human relations. As the previous chapters illustrate, individuals can make a difference in peacemaking. People who individually choose to work to prevent or end the war in their home communities are essential parts of peacemaking. Peacemaking requires individual agency and brave individuals who speak out against the war. And, peacemaking is also a group effort. Peacemaking requires agreements amongst many people to end or prevent fighting. Individual peacemakers must work with others to build movements for and groups supporting peace. One of the ways people build such momentum for peace is through networks.

Recall the stages of the Point of View process described in Chapter 7. The Point of View process went through a stage of convening catalytic workshops, in which each meeting of the Point of View process served to catalyze further confidence-building and peacemaking efforts. The workshops included internationals working both within NGOs and also intergovernmental organizations and other governments, too, on parts of the peace process. Bringing all these various actors together to share analyses of the peace process and what was needed was transformational - these workshops brought together diverse perspectives on the conflict and peace process to develop updated analyses informed by insights from all sides, and then to plan actions that would be most effective, informed by the multifaceted analysis. In a sense, these meetings were network meetings. The people connected through the Point of View process became an informal network. We can make sense of these meetings and their impact and the potential for other such group processes by considering network approaches to peacemaking.

DOI: $10.4324 / 9781003189008-8$ 


\section{Building Networks for Peacemaking}

A network is a social structure which facilitates coordination, collaboration, and cooperation amongst individuals or groups. Networks allow structured communication for achieving similar goals in situations of interdependence, which is networking. Networks and networking have been the subject of much research outside the conflict resolution field, and increasing practice and research within the conflict resolution field. Conflict resolution theory and practical experience suggest benefits of cooperation amongst conflict resolution practitioners. Systems theories, too, suggest that cooperation may lead to stronger overall results. In an era of apparently more intractable conflicts and matters of life and death, such increased efficacy is imperative.

In the search for more effective peacemaking, interest in networking has grown in the conflict resolution field in recent years. In the 1990s, those of us who cofounded the Applied Conflict Resolution Organizations Network (ACRON), which later grew into today's Alliance for Peacebuilding, sought to learn how our budding network could be most effective in supporting conflict resolution. We reached out to other fields, learning from business about the chaordic age with its adaptations away from command and control businesses to ones that flexibly responded to complex systems changes (Hock 2000). How could we engage flexible responses to complex systems changes to be most effective with networking in the conflict resolution field? My early action research work focused on ways peacemakers could coordinate with each other (Nan 1999; Nan and Garb 2006). Later (Nan 2008), I studied also ten other networks in the conflict resolution field to develop more robust guidance for effective networking for peacemaking. Such approaches acknowledge the network society aspects of our current social structures and bring a network lens to understanding conflict resolution processes (Nan 2008). Looking at regional approaches to conflict resolution, Anna Ohanyan presents a theory of networked regionalism as a promising approach to addressing conflicts through the engagement of businesses and states regionally, moving beyond the singlestate approach so common in international diplomacy (Ohanyan 2015).

The broad body of networking research suggests several considerations for networks for peacemaking, each discussed below. First, the reasons to network are important factors to consider when examining conflict resolution networks. Second, specific aspects of conflict resolution networking highlight more focused reasons to network in conflict resolution. Third, the research strongly supports the conclusion that there are multiple roles and multiple actors in conflict resolution, and that these can be complementary. However, high complementarity requires coordination, and research shows that coordination can be very difficult. Networks present one effective method of coordination particularly suited for conflict resolution coordination. There are several types of networks, some more suited to conflict resolution coordination. Thus, many factors, including obstacles, must be considered when forming a conflict resolution network. 


\section{Individuals and Groups Make Peace}

\section{Reasons to Network}

The benefits of networks, in general, are well established. A network brings people into relationships with each other. These relationships can be seen as involving resource exchange (Sarason and Lorentz 1998). A network coordinator may convene meetings that facilitate such relationships, or otherwise encourage such relationships. Furthermore, working together through networks can give organizations collaborative advantages, benefits based on partnerships (Kanter 1994). Networking can strengthen organizations and individuals. Networking offers strength through numbers. Such strength can increase political impact, access to funding, and allow a greater economy of scale. Furthermore, networking allows connections in a broader region, generally increased effectiveness, opportunities to learn from others' experiences, and psychological support and encouragement.

Reasons to network can be considered from a positive or a negative perspective. International regimes may be established to address common interests, situations participants want to achieve, or they may be established to solve dilemmas of common aversions, situations that participants want to avoid (Stein 1982). Likewise, networks can be thought of as addressing common interests or seeking to avoid outcomes that are considered undesirable by members. The positive orientation of the former, and the negative orientation of the latter, bring different perspectives to the networks.

\section{Reasons to Network in Peacemaking}

Like networks in general, there are many reasons to network in peacemaking. These reasons range from the strength through numbers that networking brings organizations generally, to specificities of complementarity and the associated coordination of conflict resolution efforts. People bring complementary skill sets and perspectives together to strengthen their shared progress towards peace. Conflict resolution organizations are notoriously under-resourced, small, independent, and individualized, but they work on very big problems as they address large-scale conflicts. Thus, there are many practical reasons to work together towards common goals.

As with networking in other fields, working with larger numbers allows greater efficiency through a greater economy of scale. For example, rather than one peacemaker learning new techniques individually, a network can allow twenty conflict resolvers to learn new techniques together, thus decreasing the teaching resources required. In addition, the strength through numbers that networking offers is highly relevant to conflict resolution activities. Networks of conflict resolution organizations and individuals can help members be heard more clearly or on a larger scale together than they would be separately. Conflict resolvers today seek a stronger voice through united actions. Such tendencies to unite through networks to reach a broader audience are not new. The pacifist movement in the United States 
between World Wars I and II depended on coordinating agencies, such as the Fellowship of Reconciliation, that appeared to represent a large coalition and thus opened up more access on a national level (Chatfield 1969).

In the Point of View meetings, no one individual participant had a broad a perspective on the peace process as the group did together. When meetings opened with sharing updates on dynamics and trends on each side of the Georgian-South Ossetian divide, all participants learned through those discussions. Some people came from one side, some from the other, and some were far from the region living internationally. All learned from the first-hand accounts of people living in the conflict region. Even those living on one side or another did not have accurate understandings of the developments on the other side, as news media did not convey the full picture and there was little opportunity for person-to-person contact to discuss developments across the divide.

Other reasons to network in conflict resolution are discussed in more detail below, in separate sections. These include first the importance of multiple roles and actors in complementary conflict resolution efforts. Secondly, the importance of coordination in such work is discussed. Finally, the utility of networks for coordination is highlighted.

\section{Multiple Roles, Multiple Actors, and Complementarity}

Ethnic or intergroup conflict today is complex and calls for a multifaceted response. No one peace initiative based on a single approach can address the various strands of complex conflicts. Instead, many approaches within conflict transformation and conflict resolution can complement each other within an overall peace process.

Substantial research describes a wide variety of intermediary roles, tasks, and functions (Mitchell 1993; Kriesberg 1998; Nan 1999) and ways they interact. Many intermediaries can contribute to an overall peace process by each playing different roles. Some roles cannot be played by the same group as their approaches are mutually exclusive (Mitchell 1993, 146). Some intermediary activities support each other, making the activities more effective in combination than either would have been alone (Kriesberg 1998; Nan 1999). There are a variety of ways in which different actors (such as different NGOs in the Caucasus) can impact each other's work (for example, actions by one NGO can pave the way for actions by another NGO, one NGO can introduce another NGO to key contacts, and NGOs working from certain platforms can play different roles not open to other NGOs, etc.) such complementarity can be sequential or simultaneous (Kriesberg 1998; Nan 1999).

Much of the previous research in this area focuses on coordination and complementarity of conflict resolution efforts within separate peace processes. Conflict resolution efforts within one peace process can be complementary, but also conflict resolution efforts in different peace processes 
can be complementary to other efforts in other peace processes. Effects can reach from one conflict to another, or from one peace process to another. The literature and practice both reveal that seemingly separate peace processes for geographically close conflicts are not entirely separate. Neighboring conflicts influence each other, as do neighboring peace processes. In other words, the conflict resolution efforts in one conflict influence those in nearby conflicts. For example, in post-Soviet conflicts, parties are well aware of the initiatives in which their neighbors in other conflicts engage.

In the Point of View process, we often learned of developments in the Georgian-Abkhaz peace process. Some of the Georgian participants in Georgian-South Ossetian initiatives were also participating in GeorgianAbkhaz initiatives. These people shared successes and also worries from that neighboring peace process. For example, Georgians and Abkhaz worked on "Dealing with the Past" with support from Conciliation Resources, SwissPeace, and others, engaging in archiving and exhibitions reflecting on the war. Some Georgians appreciated this work and the increased understanding it developed in society broadly. They shared news of the work with the South Ossetians, who became interested in developing similar approaches to the Georgian-South Ossetian war. That may become a future stage of the Georgian-South Ossetian process.

The potential complementarity of conflict resolution efforts inspires hopes to increase the overall effectiveness of peacemaking through cooperation.

\section{Increasing Complementarity through Coordination}

With the potential for conflict resolution efforts to complement each other in order to together move a conflict closer to resolution than any effort individually would, complementarity takes on a strong imperative. Coordination is a method of conscious attempts to increase complementarity. Through coordination, conflict resolvers seek to make their work more effective.

Coordination of conflict resolution efforts includes a wide range of processes relevant to networking. For example, coordination can be very loose, basic information sharing, or very structured, a formal process. Coordination can be compulsory with a coordinating body that has authority to approve or disapprove of plans, or it can be purely voluntary, etc. Networking amongst conflict resolution NGOs can similarly span a variety of functions and take a variety of forms to perform those functions.

However, coordination to fulfill these roles and increase complementarity is not easy. Coordination attempts face substantial challenges. These include competition for funding, prestige, and contacts, concerns about confidentiality, differences in underlying approach, and conflict resolution theories, poor personal relations, and a lack of resources to undertake explicit coordination (Nan 1999, 54). Networks can help overcome these coordination challenges. 


\section{Network Coordinators}

A network is most effective when it is itself coordinated internally. In other words, most networks need coordinators. Such coordinators can be formal or informal, with or without power and authority, long-term, and short-term, etc. By definition, coordinators seek to increase the efficacy of the network that they support. Research illuminates effective characteristics of network coordinators (Sarason and Lorentz 1998). In the context of Sarason and Lorentz's 1998 exploration of the roles of networks in maximizing the application of resources, the roles and characteristics of network coordinators are also considered. Their conclusions on the selection of, characteristics of, and tasks of network coordinators are useful as we consider ways to effectively network for peacemaking.

The characteristics of coordinators can be considered in four areas: knowing the territory; scanning, fluidity, and imaginativeness; perceiving assets and building on strengths; and, power, influence, and selflessness (Sarason and Lorentz 1998). Coordinators should know the territory; they should be aware of the range of people and organizations involved in the same area of work, and understand their resources, purposes, needs, programs, and history (Sarason and Lorentz, 1998. p. 95). Coordinators should quickly perceive commonalities, underlying connections, and possibilities through scanning, fluidity, and imaginativeness (Sarason and Lorentz, 1998, p. 97). Likewise, coordinators should perceive assets of individuals and groups in their network, and seek to build on strengths (Sarason and Lorentz, 1998, p. 104). Finally, coordinators should undertake their coordinating roles from positions that lack formal power, but that allow personal influence based on selfless commitment to improving the work of all in the network (Sarason and Lorentz, 1998, p. 107). Thus, a coordinator emphasizes others' strengths and has no formal power. A key contributor to each of these characteristics is the ability to talk with other people, thus getting to know them, their resources, and ideas. In addition, network coordinators are more effective when working over the long term. Long-term work in an area increases a coordinator's knowledge of the territory, ability to see underlying connections, understanding of the assets of network members, and personal influence as well.

In the Point of View process, the network was coordinated by the team of two Georgians, two South Ossetians, and two internationals. This team considered agendas for the meetings, kept in touch with participants between meetings, encouraged participants to speak up during meetings, and looked for opportunities to increase peacemaking impact. This may be unusual to have a team of six people coordinating a network, but that worked in this informal flexible way that allowed participants multiple ways to access the coordinating team. 


\section{Coordinating Through Networks}

Networks can provide an effective way to coordinate peacemaking-related activities, however, some networks are more effective than others. Factors such as formality, resource and logistical constraints, flexibility, and relationships within the network affect the network's ability to successfully coordinate members' efforts.

While formal networks are more structured, official, and clear, they may not be the best ways to coordinate. In some ways, networks may be more effective when they remain informal, that is, when they lack a legal status, appointed director, boundaries, and even written or agreed-upon rules and regulations about participation and procedure (Sarason and Lorentz, 1998, p. 92). In informal networks, members participate voluntarily through genuine interest. Flexibility is also important in a network. Networks must be sufficiently flexible to adapt to the changes that network growth and development bring. Building on members' strengths through collaboration will allow new ideas to develop and may increase the number of interested participants. As a network grows, it must be sustained through member and community participation. Certainly, the Point of View process adapted over time, as described in Chapter 7.

Flexibility can allow a network to address some of the challenges to networking, but some challenges for networking will remain. The challenges networks usually face are of four types: resource (networks require financial and human resources); geographic (distance between network members); logistical (sustaining communication links, translation as required, etc.); and, organizational (developing a participatory and effective organizational structure). The Point of View process required ongoing fundraising to attract support to cover not only the direct costs of meetings such as flights and hotel costs but also to cover the time of the coordinating team to keep in touch with participants between meetings. The distance between members was not only geographic distance, but the ceasefire line separated participants who would have been a few hours' drives from each other. We met in other countries and traveled much further to see each other. During the pandemic, however, we turned to zoom and online discussions.

The importance of relationships of friendship cannot be overstressed when examining network efficacy. Friendships may be one of the most powerful factors influencing active participation in networks. Opp and Gern (1993) found that a personal network of friends is the strongest factor encouraging participation in social movements such as the East German revolution of 1989 (Opp and Gern 1993). This finding of the importance of personal relationships of friendship in encouraging participation suggests that coordinating meetings of conflict resolvers regionally should include sufficient informal time to allow friendships to develop and also to allow ongoing friendships to grow. Often in Point of View coordinating team discussions, we shared our personal news - someone's daughter got married, another's family planned to open a restaurant, etc. 


\section{Factors for Consideration in Network Establishment}

The current knowledge on networks suggests that networking amongst conflict resolution NGOs will be most effective when beginning with loose voluntary association which grows through relationship building, gradually building more structure and authority as it develops. No NGO wants to give away its authority until it trusts a networking body of people that it knows. Less threatening but very useful functions of a network of conflict resolution NGOs would be voluntary engagement in:

- Information sharing (Who is doing what, where, when, and why? What has and hasn't worked well with these activities? What resources are available to support such activities?)

- Development (How can conflict resolution NGOs access supportive resources? What kinds of structures work within conflict resolution NGOs?)

- Problem solving on issues of mutual concern (How do local NGOs work with international partners constructively? How do local NGOs maintain strength when approaching unpopular political views?)

- Network development (Who else do we want to be in contact with? What other expertise can help us make peace? How, where, when, and why will we meet again? What other functions do we want our network to serve? How do we need to structure our network to fulfill these functions?)

- Overcoming networking challenges (Consider competition for funding amongst many groups, sensitivity to confidentiality, scarcity of time, personal attention, and resources, and that different approaches to conflict resolution which may be in conflict with each other.)

These suggestions emerge both from the coordination literature and from action research observation of the practices of networking. In addition, the practice suggests further guidelines for effective networking. For example, the literature suggests that a more developed network could eventually organize conferences on themes of mutual interest, provide a clearinghouse on literature of mutual interest, engage in concrete projects through partnerships of member groups or as a network, etc. However, the Caucasus Forum, as described below, was able to undertake a project of mutual interest as a network very early in its development. Let us turn, now, to considering the practical insights that emerge from the experience of networking undertaken in the context of the Commonwealth of Independent States Conference Working Group on Conflict Management and Prevention.

\section{CIS Working Group Networks}

Networking regionally amongst conflict resolution practitioners is one form for such cooperation. In the 1990s, the United Nations High Commission on 
Refugees (UNHCR) Commonwealth of Independent States (CIS) Conference on Refugees and Migrants and the working group that the conference established, the Working Group on Conflict Management and Prevention, began peacemaking networks. In November 1998 the first Working Group meeting established a priority to organize networks of conflict prevention and management NGOs in the CIS. In 1999, the Working Group set about developing two regional networks for peacemakers. Engaging in action research with these budding networks, I sought to identify what was working well within the networking efforts, and what guidance these efforts might provide for others seeking to strengthen peacemaking through networking. Participant observation in 1999 with local NGOs attempting to network formed the center of the action research. Two regional processes were engaged in the action research, first in the Caucasus and then in Central Asia. Both processes were in post-Soviet regions and both developed with the assistance of an international and western partner, International Alert, a major conflict resolution NGO. The focus of the 1999 action research was on the establishment of the networks.

The Caucasus Forum and the Central Asia Forum presented different experiences, growing out of their different contexts. For example, the Caucasus Forum developed out of a strong need for multilateralism that local participants identified in light of the many cross-cutting conflicts in the region. In contrast, the Central Asian Forum developed with a greater interest in conflict prevention. A major difference between the networking processes is the smaller number of violent conflicts in Central Asia at present in contrast to the seven major conflicts in the Caucasus. This impacted networking dynamics additionally through the further professional development of conflict resolution-related NGOs in the Caucasus in comparison to the fewer experienced NGOs in Central Asia.

Within the UNHCR CIS Conference on Refugees and Migrants, a Working Group on Conflict Management and Prevention was established. This working group was reestablished and began activities in 1998, with the Centre for Conflict Management, Kazakhstan, acting as lead agency for the Working Group. The Working Group first met in November 1998. This meeting brought together thirty participants representing conflict management-related NGOs and international organizations based in 14 CIS countries and regions: Abkhazia, Armenia, Azerbaijan, Chechnya, Dagestan, Georgia, Ingushetia, Kazakhstan, Kyrgyzstan, North Ossetia, Russia (including the Stavropol Krai Tajikistan, and Ukraine. The meeting resulted in a Working Group commitment to organize a network of NGOs for cooperation in conflict management and prevention in the CIS, as well as the identification of a second lead agency, International Alert.

International Alert and the Centre for Conflict Management shared responsibility for implementing the Working Group mandate of establishing a network. In order to work to meet regional needs, International Alert took leadership in bringing together potential network participants from the 
Caucasus. The Centre for Conflict Management took the lead in bringing together potential network participants from Central Asia. Each of these two network establishment processes is described below.

\section{The Caucasus Forum}

The Caucasus Forum was developed based on the needs local participants expressed to have a multilateral forum of contacts and activities. International Alert was working on a trust and confidence-building program between the civil society sectors in Georgia and Abkhazia. The participants in the first April 1998 Sochi workshop developed the idea of the formation of a Caucasus Forum of NGOs for Peace. Thus, the second workshop in the series was devoted to the initiation of the Forum. This second workshop was held in July 1998 in Nalchik.

The July 1998 meeting culminated in a hike up Mount Elbrus, and the subsequent Elbrus Declaration. This declaration established the Caucasus Forum. Participants in the establishment process reported that the walk together on the mountain provided a sense of community and social activities amongst the participants that created a group atmosphere that allowed such a declaration. Thus, informal relationships built multilaterally around shared interests formed a solid foundation for the establishment of the Caucasus Forum.

The Caucasus Forum is an innovative exercise of cross-cultural, crossborder, and cross-conflict cooperation. Its success can be traced to both theoretical and practical sources. Practically, the situation and conflicts in the Caucasus provided a strong impetus to multilateral peace-building efforts.

The multilateral aspect of the Caucasus Forum was an impetus to its establishment and maybe a strong factor in its success. Until the establishment of the Caucasus Forum, external preference to the bilateral format of Georgian-Abkhaz conflict resolution work had been overwhelming, because the assumption has been that the two belligerents should meet and make peace together. This same dynamic has applied to most of the conflicts in the Caucasus. Most internationally instigated conflict resolution efforts sought to bring two primary sides to each conflict together. However, for a variety of reasons, in most of the suspended conflict situations in the Caucasus today, the sides in the conflict are reluctant to meet in a bilateral format, especially at the civil society level.

International Alert supporter of the Caucasus Forum, Gevork TerGabrielian, reflected on the multilateral aspect of the Caucasus Forum as it was forming (Ter-Gabrielyan 2012). Ter-Gabrielian suggested, and the subsequent Caucasus Forum experience confirmed, that many aspects of conflicts in the Caucasus can be tackled, and confidence built more easily, in a multilateral environment than in a bilateral one, given the divergent interests of the actors directly involved in a conflict. In a multilateral format, the interests of NGOs from different localities balance each other; they 
create coalitions to lobby their interests within the Forum, and therefore no effective unilateral pressure is possible.

The multilateral format of the Caucasus Forum also overcame isolation and disempowerment felt by the overwhelming majority of NGOs in the Caucasus. In fact, new projects for which the NGOs separately did not have leverage to implement became possible through combined efforts. For example, the Caucasus Forum meeting of Former Combatants was only possible because it was a multilateral meeting. As former combatants command high respect within their communities and from their governments, their coming together and strengthening of resolve to avoid violent resolution of conflicts in the future was a strong step in regional peacebuilding and in more focused conflict resolution work on the conflicts represented in the multilateral setting.

As Ter-Gabrielian also noted (Ter-Gabrielyan 2012), twisting and distorting facts is more difficult and less effective in a multilateral environment than in a bilateral one. Often, in a bilateral setting, two sides advance their views and become entrenched in incompatible positions concerning their interpretations of events. In a multilateral setting, these focal points of disagreement either become irrelevant and more universally salient issues are selected for discussion, or they are enriched by the interpretations of other participants who, as neighbors, do not feel in the false position of a detached international mediator and have their obvious stakes in keeping good relations with both sides of a particular conflict. There is not a single conflict in the Caucasus that lacks a third (or more) side(s) interested in keeping good relations with both sides directly involved in a conflict.

Because of all of the above, Ter-Gabrielian concluded and my experience with these networks confirms, multilateralism makes compromise easier to achieve in these contests; however, it constrains the depth of the issues discussed and agreements reached. The drawback of multilateralism is that it makes the levels of agreement 'superficial'. The point of agreement is usually formulated in very vague terms so that every party has the latitude to interpret it at least slightly differently, in a way that suits their internal political purposes. This could make the agreements detached from everyday actions, and sometimes irrelevant. As different from bilateral ones, multilateral agreements are not so much violated or broken as freely interpreted and twisted. That is why they hold usually only at those points where the interests of all the parties strongly coincide. In the best case, they represent the point of strong universal commitment; in the worst case, they are just a piece of paper. Given these strengths and weaknesses of multilateral work, it is clear that multilateral work can only complement, not take the place of, bilateral work.

\section{The Central Asian Forum}

International Alert assisted the Conflict Management Centre in Almaty, Kazakhstan with the planning and facilitation of a September 1999 meeting 
of conflict resolution NGO representatives from Central Asia. The Central Asians gathered together for one meeting only at the close of the course of my action research engagement, so I cannot describe the development of the Central Asian network over the course of time here. However, this network already differed from the Caucasus network in its beginning phase. The Central Asian network is focused more on conflict prevention and early warning, due to the nature of the conflict situations in Central Asia. In addition, the NGOs in Central Asia are not as experienced in conflict resolution as those in the Caucasus.

\section{Principles of the Caucasus Forum and the Central Asian Forum}

International Alert structured its approach to developing networks of conflict resolution groups in the Caucasus and Central Asia in accordance with the International Alert Code of Conduct ("Code of Conduct: Conflict Transformation Work" 1998). These principles guide International Alert's work in each of its programs. The principles highlight aspects of the International Alert approach that shaped these networking efforts.

- Primacy of people in transforming conflicts. The International Alert networking efforts are aimed at developing networks that strengthen local approaches to local conflict situations, thus encouraging those most affected by conflicts to participate in peace processes. (Note the relevance for our discussion of people-centered approach to interactive peacemaking: the primacy of people.)

- Humanitarian concern. A desire to alleviate human suffering due to conflict motivates participants in the Caucasus Forum and Central Asian Forum as well as International Alert staff supportive of these developing networks.

- Human rights and humanitarian law and principles. Human rights concerns are considered within the conflict resolution networks whose establishment International Alert facilitated. Indeed, human rights experts are involved in each network.

- Respect for gender and cultural diversity. The networks have been established with sensitivity to gender and cultural diversity, and efforts to include men and women of varied ethnic backgrounds in the networks. When no people of Kazakh nationality were represented at the first meeting of the Central Asian Forum, this became a cause for concern, and participants and organizers agreed to increase efforts to involve Kazakh conflict resolution partners in the network.

- Impartiality. The networks, like International Alert, have not taken sides in conflicts, but have taken stands against violence in conflicts.

- Independence. The networks have developed as independent organizations, in association with the Working Group on Conflict Management and Prevention of the UNHCR-sponsored CIS Conference. 
- Accountability. The networks, like International Alert, are responsible to those they seek to assist and to their donors.

- Confidentiality. The networks have respected the confidentiality of individual statements at their network meetings.

- Partnerships. The networks embody partnership as a core principle of their existence. The networks came into being through partnership with International Alert and the networks themselves encourage partnership amongst member organizations.

- Institutional learning. International Alert has remained committed to reflecting on the process of network development with network participants and actively seeks to share lessons learned with other interested individuals and organizations. My having found a welcoming environment for action research on networks with International Alert is a credit to the organization's commitment to learning.

\section{Other Conflict Resolution Networking Experience}

Two other conflict resolution networking experiences form a background comparison within this study. These networks are conflict resolution groups for which the author has facilitated meetings over the course of their development, though not as the main coordinator for either network. Both involve unofficial individuals based on either side of a post-Soviet sovereignty conflict and reaching across the conflict line towards peacebuilding.

\section{Networking in Moldovan-Transdniestrian Conflict Resolution}

A strong network of six Moldovan and Transdniestrian individuals worked together to organize many peacemaking initiatives in their region for several years in the late 1990s. This network emerged from a grassroots interest in peacebuilding, and gradually formed a more formal structure with assistance from an international conflict resolver and grew to engage official negotiators from both sides in peacemaking discussions. The group became known as the Joint Committee for Democratization and Conciliation (JCDC). This group worked often with the Moldovan Initiative Committee on Management (MICOM) to engage international expertize in MoldovanTransdniestrian conflict resolution work. One such initiative brought together a larger and temporary grouping of interested individuals in a loose network structure.

As a result of JCDC work, a group of 60 Moldovan and Transdniestrian people representing NGOs and local authorities gathered together in September 1999 in Albena, Bulgaria, to plan conflict resolution and peacemaking-related activities in their home regions. The participants conducted an analysis of their strengths, weaknesses, opportunities, and threats with regard to their efforts to address the conflict situation. Their strengths focused on their connections to each other: work as a team, wide contacts, 
knowing needed people in needed places, uniting people of different regions, interests, and professions, and commitment to our work. Likewise, the opportunities the participants identified focused on networking: uniting NGOs, joint use of resources, sharing an informational base, developing international links, and exchanging experience.

This Albena process was networking from the bottom-up, driven by the grassroots. Individuals came up with ideas to work on together without direction from a coordinator or organizer. However, such a bottom-up approach is not organized for follow-through on long-term work. Indeed, the Albena process later struggled with implementation of projects developed through the interactive network. More support from a stronger network structure might assist more project implementation but might also hinder the creativity and freedom through which individuals voluntarily work together to develop proposals that meet the needs they observe in their communities.

\section{Networking in Georgian-Abkhaz Conflict Resolution}

Dr. Paula Garb at the University of California at Irvine organized a long-term series of meetings between Georgians and Abkhaz interested in citizen diplomacy toward increased understanding between their societies. These meetings occurred two or three times a year for several years, focusing on one core group of interested individuals. This focused network remains very informal, built on the strength first of respect for Dr. Garb as coordinator and secondly on the respectful Georgia-Abkhaz relationships built over the course of the meetings. The long-term relationships built through a developing group identity with participants in the meetings has allowed more significant attempts to understand each other across the conflict line than short-term relationships allow. Garb and I described this coordination network's inspiration: "the locally recognized organic need for coordination drove the development of the network through an elicitive process" (Nan and Garb 2006, 7).

\section{Guidelines for Effective Networking in Conflict Transformation}

Having considered several different approaches to networking in conflict transformation, it is possible to draw out aspects of each approach that have proven effective in networking. Before turning to general guidelines, however, it is important to remember that the goals of a network relate to the shape that a network should take in order to meet those goals. The goals of a network should respond to the needs a network seeks to meet and should shape consideration of basic network formation considerations:

Network size. A smaller network will have more trust amongst members who will be able to engage in more difficult work together. A larger network will bring more external visibility to group efforts.

Network facilitation and coordination. A strong international network facilitator will help network members work through difficult issues of 
network formation, while a peer facilitator will help network members develop their own decision-making culture to address these and future issues. A team of two complementary facilitators is an effective answer to these competing interests.

Bottom-up vs. top-down establishment process. Networks that are established based on grassroots needs and with grassroots participation will have strong participant ownership of the network. Participants will be more active in such networks.

Highly structured (formal) vs. loosely structured (informal). More structured networks will allow greater network size, more focused work together across distances, and allocation of network-resources. A less structured network may be smaller, involve stronger personal relationships and personal commitment, and engage in more complex tasks.

Centralized vs. decentralized. A highly centralized network allows quick responses and unified focused leadership at the expense of participation. A decentralized network trades efficiency and unified visions for participation and widespread approval of network endeavors.

Relations with other networks. Networks that relate to others must structure themselves enough to clarify representation issues, while other networks may allow crossover of individual networks without requiring additional institutionalization of the network.

\section{Basic Principles of Networking}

Relationships matter. Networks are built around the strength of relationships amongst members and relationships of members with coordinators. Effective network coordinators have been well respected by most network members, and willing to work on relationships with others.

Long-term work builds stronger results. As with most aspects of conflict resolution work, networks cannot be magically built into strong and lasting relationships overnight. Long-term work allows network development organically related to the needs of network members. Such strong roots allow a network to develop.

Multilateralism changes dynamics. The networks amongst two sides of a conflict and the networks amongst many sides to many conflicts in one region are very different. The latter networks involve multilateral gatherings in which the saliency of identity as conflict enemies changes meaning in the context of many other identities and many other conflicts. However, multilateral relationships allow tensions between those parties with interests in the status-quo (recognized states) and those with an interest in change (unrecognized areas). Multilateral relationships within a network allow conflict resolution work focussed on different issues than bilateral work, thus the multilateral environment of a larger conflict resolution network can complement more focussed conflict resolution work. 
These principles of networking suggest steps for organizing a successful peacemaking network:

1 Identify a need; the need becomes the driving rationale for the network.

2 Identify those who share that need.

3 Get to know those who could contribute to and benefit from a network.

4 Clarify network goals

5 Establish network ground rules.

6 Establish network ownership amongst members.

7 Explore network activities. Networks will gain momentum through involvement in concrete activities with tangible results.

8 Encourage friendships amongst networks members.

9 Expand or develop network in accordance with goals and context.

10 Clarify and re-clarify network decision-making, values, principles, and boundaries.

11 Acculturate new members as appropriate, establishing shared network ownership, and returning again and again to the big picture need the network addresses.

12 Support the network logistically. Develop an institutional structure supportive of network continuity.

13 Encourage informal as well as formal communication throughout the network.

14 Create a process for accommodating changes in the network environment.

15 Allow network adaptation and evolution, revisiting the overall need the network addresses.

Networks should respond to needs of peacemakers to increase their efficacy through working together. As these needs vary from context to context, networks must vary to respond to these needs. Over time, even a welldeveloped network must remain flexible to respond to the changing context of the network. I offer this guidance with hope of contributing to the vitality and success of a variety of peacemaking networks.

Of course, in line with the book's main theme, networks are only possible because of the people who make up networks. People bring their passion for the needs the network addresses, their resourcefulness and energy, and skills to the network. Without people, the network is empty.

Next, we turn to a synthesis of the key points of this book, and the guidance these insights suggest for peacemaking.

\section{Works Cited}

Chatfield, Charles. 1969. "Pacifists and Their Publics: The Politics of a Peace Movement." Midwest Journal of Political Science 13 (2): 298-312. 10.2307/211 0180 . 
"Code of Conduct: Conflict Transformation Work." 1998. International Alert. https:// www.international-alert.org/sites/default/files/library/Code $\% 20 \mathrm{of} \% 20$ Conduct.pdf.

Hock, Dee. 2000. "Birth of the Chaordic Age." Executive Excellence 17 (6): 6.

Kanter, Rosabeth Moss. 1994. "Collaborative Advantage: The Art of Alliances." Harvard Business Review 72 (4): 96-.

Kriesberg, Louis. 1998. Constructive Conflicts: From Escalation to Resolution. Lanham, MD: Rowman and Littlefield Publishers.

Mitchell, Christopher R. 1993. "The Process and Stages of Mediation: Two Sudanese Cases." In Making War and Waging Peace: Foreign Intervention in Africa. Washington, D.C.: United States Institute of Peace Press.

Nan, Susan Allen. 1999. "Complementarity and Coordination of Conflict Resolution Efforts in the Conflicts over Abkhazia, South Ossetia, and Transdniestria." Doctoral disseration. Fairfax, Virginia: George Mason University.

Nan, Susan Allen. 2008. "Conflict Resolution in a Network Society." International Negotiation (Hague, Netherlands) 13 (1): 111-131. 10.1163/138234008X297995.

Nan, Susan Allen, and Paula Garb. 2006. "Negotiating in a Coordination Network of Citizen Peacebuilding Initiatives in the Georgian-Abkhaz Peace Process." International Negotiation (Hague, Netherlands) 11 (1): 7-35. 10.1163/1571 80606777835748.

Ohanyan, Anna. 2015. Networked Regionalism as Conflict Management. Stanford, California: Stanford University Press.

Opp, K-D, and C Gern. 1993. "Dissident Groups, Personal Networks, and Spontaneous Cooperation: The East German Revolution of 1989." American Sociological Review 58 (5): 659-680. 10.2307/2096280.

Sarason, Seymour Bernard, and Elizabeth Lorentz. 1998. Crossing Boundaries: Collaboration, Coordination, and the Redefinition of Resources. 1st ed. San Francisco, Calif: Jossey-Bass Incorporated.

Stein, Arthur A. 1982. "Coordination and Collaboration: Regimes in an Anarchic World." International Organization 36 (2): 299-324. 10.1017/S0020818300018968.

Ter-Gabrielyan, Gevorg. 2012. "The Experience of the Caucasus Forum: An Experiment in Holistic Peacebuilding." In Mediation and Dialogue in the South Caucasus: A Reflection on 15 Years of Conflict Transformation Initiatives. London: International Alert. 


\section{Peacemaking Is Personal}

This short chapter presents an analysis of the characteristics of successful peacemaking processes. It also offers practitioners a synthesis of practical guidance that emerges from considering peacemaking experience. Finally, the chapter concludes with the core arguments of the book, offering scholars a synthesis of the theoretical insights and reflecting on their significance for peacemaking.

\section{Characteristics of Successful Peacemaking Processes}

Some basic characteristics are common to many successful peacemaking processes. Among other things, these processes:

- Are possible. Participants must be willing to participate in them, and this happens when they see the processes as reasonable and when they offer a high potential reward in comparison to the risk of participation. Outsiders might design an elegant process that makes sense from the outside, but if no one is willing to participate then the process will not work.

- Are safe enough. Peacemaking processes must be safe enough to attract participants, who must weigh their own sense of how far they can reach across dividing lines without angering their home communities, where peacemakers can be seen as traitors for engaging with the enemy.

- Push the envelope without tearing it. Peacemaking should expand the space for engagement without provoking a backlash against the process. In other words, if participants are only willing to speak about humanitarian issues (as was the case when Georgians and South Ossetians first met after the August 2008 war), then start by speaking about humanitarian issues. Gradually, other topics can be engaged, once participants are ready. If a peacemaking process tries to go too far too fast, participants can be punished by their home communities, causing future peacemaking initiatives to be canceled or further constrained. In South Ossetia in 2010, Timur Tskhovrebov was beaten up after he returned from a dialogue convened by IKV Pax Christi, where he and Georgian dialogue 
participants had together signed a call for official participants in the Geneva International Discussions to focus more on the needs of the population ("South Ossetia: Activist Brutally Assaulted" 2010).

- Follow the lead of locals living the conflict. Those who live in the conflict context will have the most attuned sense of local dynamics as the space for engagement shifts over time. While they may sometimes "push the envelope" too far, as was the case with Tskhovrebov, they are less likely to do so than outsiders who lack a precise understanding of local sensitivities. Maximizing local leadership both increases the context relevance of the peacemaking and its sustainability. Internationals come and go, but locals more often stay in their home communities through the ups and downs of the peace process.

- Are sensitive to the specific context. Conflicts are context-specific, and conflict resolution processes must engage with the cultural specificities of each unique context. Peacemaking processes cannot be created as recipes that we can cut and paste from one context to another.

- Change over time. As conflict contexts change, peacemaking processes need to adapt, too.

- Include reflective practice and participatory evaluation. Reflective practice approaches such as debriefing and team reflections support shared analysis within the peacemaking team and core participants. The evaluation process can be a conflict resolution process, as individuals across deep divides engage together to consider their goals and progress.

- Offer something new. The status quo, without new input, by definition will not make peace in a place of conflict. Peacemaking processes must introduce something new in order to move toward peace. The new something could be: shifts in substance, procedure, consciousness, or relationships (Nan 2005, 2011); ideas for solving problems (Mitchell and Banks 1996); catalysts for new confidence-building measures (Nan and Greiff 2013); or other input.

- Transfer beyond the immediate process. Ronald Fisher defines "transfer" as: "the process by which individual changes (e.g., improved attitudes, new realizations) and group products (e.g., frameworks for negotiation, principles for resolution) are moved from the unofficial conflict resolution interventions to the official domain of negotiations, policymaking, and the surrounding political culture" (Fisher 2020). In other words, what happens in a peacemaking context must not stay in that (immediate) peacemaking context.

- $\quad$ Engage both those who are most open to peacemaking and, eventually, those who are more skeptical. Peacemaking processes often start with those who are the most open to engaging across divides, but they will not be successful until the main skeptics are convinced to engage. One group of Georgian and South Ossetian peacemakers described their goal as to "gradually expand the circle of those involved" while still maintaining the 
openness to constructive conversation that more experienced peacemakers had built through earlier meetings together.

- Cover essential costs. Pragmatically, there are costs involved in peacemaking. Who will cover the costs of the meeting space? Are professional translators required? Can participants cover their own travel, lodging, and meal costs during the discussions? Who will cover facilitators' time for preparation and actual facilitation? If people who would otherwise be making peace are instead working long hours to feed their families, then peace will not get made.

\section{General Guidance for Peacemakers}

While it is true that each peacemaking approach must be customized and relevant to each particular context, the experience of successful peacemakers suggests the following general guidance:

- Clarify peacemaker positionality and approach to impartiality. People entrenched in conflict want to know where the people who approach them as peacemakers stand. I clarify my positionality as a US citizen who does not always personally support the decisions of the US government, and as a person partial to nonviolent resolution of conflict and the prevention of war and impartial to the specific political arrangements that result from nonviolent settlements. As I navigate my impartiality in relation to the political arrangements under dispute in the Georgian-South Ossetian conflict, Georgians tend to criticize me for not standing up for Georgia's territorial integrity and South Ossetians tend to criticize me for not standing up for South Ossetia's independence. Peacemaking with a people-centered approach requires a focus on process more than outcomes. As a peacemaker, I am mostly impartial about outcomes (Georgia's territorial integrity or South Ossetia's independence) but I am quite partial to process. I want all people to have a say in shaping their future.

- Keep showing up. South African peacemaker Susan Collin Marks taught me the importance of having international peacemakers continuously returning to the people most intensively involved in peacemaking, to check in on how they are doing and any changes in the situation, to offer a listening ear, and to ask if they can be of any assistance (Marks 2009).

- Listen. Much more important than what peacemakers say is how they listen. Many times, individuals in conflict situations have thanked me for listening to them. And, feeling satisfied that they have been heard, people are then open to becoming listeners themselves. Listening is essential to peacemaking.

- Conduct joint analysis. Rather than having each person present their own analysis as a solid conclusion, peacemaking processes can engage participants in shared analysis, through which they learn together. Each 
brings part of the puzzle and draws on their own expertise. In the Georgian-South Ossetian discussions, we typically take time for those coming from Georgian-controlled areas and from South Ossetiancontrolled areas to share updates on developments in their respective regions. Sometimes we also have those engaged in international discussions on the conflict share developments, and then the group works together to try to make sense of the overall shifts in dynamics, as seen from these various perspectives. On other occasions Georgians and South Ossetians have engaged with a new analytical framework, working through how that framework might shed light on aspects of their respective experiences. For example, Lara Olson led Georgian and South Ossetian coordinators through a systems mapping exercise analyzing the dynamics in the conflict and how they influence each other - to look together at the shifting context of the peace process and to reflect on where our efforts might have the most impact.

Likewise, the Life and Peace Institute in Somalia convened communities for shared analysis of their conflicts that turned into a conflict resolution effort (Elder 2016). Others have walked participants through history in an exercise that has each participant illustrate their own version of a timeline of significant developments in the conflict (Arai 2015; Gamaghelyan 2017).

- Engage over the long-term. Peacemaking processes take time. Peacemakers must be ready to engage for many years. Pragmatically, long-term engagement requires sustainable practices that protect the health and basic financial stability of all involved.

- Build relationships. Peacemaking requires deep personal trust, embedded in real friendships among people who take risks to build peace in their home communities.

- Engage the strengths of local peacemakers and, where necessary, international peacemakers. Local peacemakers will generally know their own context better, but international peacemakers may bring ties to donors or connections to other peacemaking processes that provide useful examples and comparisons.

- Work with the platforms people bring to the process. Each peacemaker, both local and international, brings their own platform to the process. I am a university professor, and I bring a university platform to the process. I can host a university-based symposium as part of the peacemaking process and sometimes, South Ossetians have explained, this is preferable because at times their home community has asked them to engage only in academic discussions with Georgians. Others work in journalism and can influence public opinion. Still, others work with senior leadership in their communities and can influence the official governmental positions, and others have contacts with donors who might agree to support the costs of the peace process and its implementation. Each peacemaker brings their own set of connections, constraints, and possibilities. 
- Let go of control. Peace cannot be forced. It cannot be controlled. Peace can be made when people choose peace. So, peacemaking means a process of inviting people to choose peace, and that choice must be freely made.

- Coordinate within multifaceted peace processes. Most peacemaking involves multiple pieces and processes, with multiple intervenors who engage in different and sometimes overlapping parts of the conflict. There is no one initiative that is the one key to making peace. Coordination and complementarity can enhance overall impact (Nan 1999). In the case of the Georgian-South Ossetian and Georgian-Abkhaz engagements, the United Nations convenes a Joint Coordination Forum that encourages coordination between the various internationals that intervene in these peace processes. The delineation of separate areas of attention and emphasis can help ensure that discrete interventions do not complicate the work of others. With multiple initiatives simultaneously underway, one initiative can survive even if another one is criticized or shut down by a mishap.

- Keep learning. Each peace process has its own people and history. Keep reflecting, evaluating, and learning what works in that peace process. With the larger goals of peace in mind, consider what in this specific context will help more towards peace? And, share what you learn. Insights in one context may help peacemakers in another context.

\section{Conclusion}

Overall, this book has demonstrated that peacemaking is personal. Yes, there are states and institutions and structures and power dynamics and military actions and all sorts of other factors involved in peace and conflict. These factors and so many structural factors matter. They constrain possibilities. And, the people involved are also central to all of this. Individuals make choices outside of the limelight that shape peace processes. Both structure and agency matter.

The recognition that people do make a difference for peace provides some optimism for a world too troubled by war. The ability of individual people to make a difference, sometimes in small and local ways and sometimes in larger ways in concert with others, provides reason for hope. Still, we must ask, if people have the ability to make peace, why don't we more often do so?

One reason may be that we do not know we can make a difference. The way wars and peace agreements are discussed in the news, seems to be made only of the actions of political and military leaders. This book provides evidence to the contrary, illustrating that behind the scenes, out of the limelight, there are individuals without significant political power who do pave the way for peace. When people know they can make a difference, they will be more inclined to try to do so. 
Another reason may be that so often our attempts to make peace fail, and so we may be discouraged from trying. The stories in this book reflect people who took a chance, tried something that might have failed, and in taking those risks they made progress toward peace. Making peace requires taking chances. We make space for peace to emerge, not at all certain that it will. There are no guarantees in peacemaking. Peacemakers are willing to try where they might fail.

Still another explanation may be that we do not know how to make peace. Generally, we have not studied peace as much as we have studied war. For this concern, the book offers a small contribution to studying peacemaking. More is needed to guide those who wish to make peace in their home communities or more broadly. Some of the existing guidance for peacemakers lies behind firewalls, accessible in university libraries or with expensive subscription fees. One initiative of the Better Evidence Project at George Mason University is to provide open access to evidence-based guidance for practitioners, policymakers, donors, and scholars on what works in what contexts for peacemaking. ${ }^{1}$ As we learn from successes and failures, we can do better with future peacemaking.

This book has emphasized ways of learning from experience. By examining current peacemaking practice, we can improve future peacemaking practice. The learning from practice approach puts a burden on current practitioners, not only to make peace now but also to share the insights they gain through experience with future peacemakers. Reflective practice strengthens current practice, while also paving the way for future peace efforts. Adding learning from practice to traditional academic research strengthens our collective knowledge of how to make peace.

Further expanding our ability as a field to learn from practice will require further shifts. We need more opportunities for practitioners to reflect and share their insights, more opportunities for mentoring new peacemakers, more opportunities for scholars and practitioners to work collaboratively, and we need to teach peace practices more broadly so that more peacemakers can take a chance on making a difference for peace in their home communities. All of this requires also reinforcing a developmental mindset that we can continue to improve our peace practices by learning from experience, whether through action research, reflective practice, evaluation, or other engaged scholarship.

Peacemaking demands perseverance and teamwork. The stories include in this book of individuals making a difference were only possible because these people took a chance, kept at it, and worked with others. No one person did it all alone.

Peacemaking is necessary for human survival. Current and future generations demand we improve our peacemaking. Each reader of this book can do something for peace. Please, reflect on what you can do, and take action. 


\section{Note}

1 See bep.carterschool.gmu.edu.

\section{Works Cited}

Arai, Tatsushi. 2015. "Engaging Conflict History: Toward an Integrated Method of Conflict Resolution Dialogue and Capacity Building." Conflict Resolution Quarterly 32(3): 277-98. https://doi.org/10.1002/crq.21113.

Elder, C. 2016. "Participatory Action Research (PAR), A Tool for Transforming Conflict: A Case Study from South Central Somalia." Life and Peace Institute. http://life-peace.org/wp-content/uploads/2016/07/Somalia_PAR_WEB-1.pdf.

Fisher, Ronald J. 2020. "Transfer Effects from Problem-Solving Workshops to Negotiations: A Process and Outcome Model.” Negotiation Journal 36(4): 441-70. https://doi.org/10.1111/nejo.12336.

Gamaghelyan, Philip. 2017. "Conflict Resolution beyond the International Relations Paradigm: Evolving Designs as a Transformative Practice in Nagorno-Karabakh and Syria." Soviet and Post-Soviet Politics and Society, Vol. 171. Stuttgart: Ibidem-Verlag.

Marks, Susan Collins. Interview with the author. Washington, D.C. February 20, 2009.

Mitchell, Christopher, and Michael Banks. 1996. Handbook of Conflict Resolution: The Analytical Problem Solving Approach. New York: Pinter.

Nan, Susan Allen. 1999. Complementarity and Coordination of Conflict Resolution Efforts in the Conflicts over Abkhazia, South Ossetia, and Transdniestria. Fairfax, Virginia: George Mason University.

Nan, Susan Allen. 2005. "Track One-and-a-Half Diplomacy: Contributions to Georgian-South Ossetian Peacemaking." In Paving the Way: Contributions of Interactive Conflict Resolution in Peacemaking, 161-73. Lanham, Maryland: Lexington Books.

Nan, Susan Allen. 2011. "Consciousness in Culture-based Conflict and Conflict Resolution." Conflict Resolution Quarterly 28(3): 239-62. https://doi.org/10.1002/ crq. 20022.

Nan, Susan Allen, and Jacquie L. Greiff. 2013. "Basic Human Needs in Practice: The Georgian-South Ossetian Point of View Process." Conflict Resolution and Human Needs: Linking Theory and Practice, edited by Kevin Avruch and Christopher Mitchell, 202-15. New York: Routledge.

"South Ossetia: Activist Brutally Assaulted." 2010. Human Rights House Foundation (blog). August 3, 2010. https://humanrightshouse.org/articles/south-ossetia-activistbrutally-assaulted/. 


\section{Index}

abduction 21

Abu-Nimer, Mohammed 61

action evaluation $26,31,55$

action research 2-3, 5, 21, 27-29, 31, 33, 119-20, 123-24, 134

agency, individual agency $7,32,61,85$,

$102,112,120,133$

Alford Lake Camp 53-54

Allen, Doris 20, 37, 53

Almengor, Rochelle Arms 20-21, 29

Appalachia 61, 64

Arai, Tatsushi 24, 84

Argyris, Chris 18, 24

Aristotle 18

August 2008 war 1, 14-15, 42, 47-50, 92-93, 95, 98, 103, 129

Babbitt, Eileen 20, 61

Bartoli, Andrea 18

Bougainville 40

Burton, John 2

Camplisson, Joseph 56, 62

Carter Center 68

Carter, Jimmy 69, 77, 91

catalytic workshop 26, 105-106, 112

Caucasus Forum 98, 119-23

Center for Peacemaking Practice 15

Center for the Study of Mind and

Human Interaction (CSMHI) 70

Central Asia Forum 120, 123

Chevening Scholar 52

Chigoev, Merab Iliich 38-40, 51-52

Children's International Summer

Villages (CISV) 53

chocolates 67-68

Clements, Kevin 4, 54
Cobb, Sara 20

Code of Conduct 2, 123

complementarity $21,41,55,113-16$, 133

complexity 30, 42, 91

Conciliation Resources 20, 27, 116

consciousness, shifts in consciousness 29 , $65,83,130$

coordination 16, 21, 24-26, 41, 55, 65, $76,98,113-16,119,125$

Coppetiers, Bruno 22

Cost of Conflict 15, 22, 86, 103, 108-10

COVID 52, 96, 110

Crick, Tom 68

D'Estree, Tamra Pearson 20, 25, 61

Dartmouth Dialogue 66

Diamond, Louise 60

Docherty, Jayne 20

Dugan, Moire 15, 19, 33, 62, 64, 86

embodied engagement 65-66

environmental activists 61, 65-65

Estonia 20, 54, 61, 70, 74-77

Evaluation, formative evaluation 3, 5, 21, 25-28, 31, 105, 130, 134

Fisher, Roger 20, 52

Fisher, Ronald 2-3, 20, 61, 130

Frasure, Robert 76-77

Gali, Boutros Boutros 1-2, 12, 15

Galtung, Johan 1

Gamaghelyan, Philip 4, 20, 86

Gamsakhurdia, Zviad 13

Garb, Paula 4, 15, 20, 26, 43-45, 49, 55, $67,81,125$ 
Geneva International Discussions (GID)

$23,26,28,51,60,92,103,107-108,130$

genocide 14

Georgian language 10-11

humility $46,81-82$

hybrid peace 3

Incident Prevention and Response

Mechanism (IPRM) 16, 26, 28, 38, 60, 92, 103

incremental approach to peace 17

insider and outsider roles $86-87$

insider-partials 87

interactive conflict resolution $2-3,5$, 7, 83

interiority 65

International Alert 120-24

irrigation 16-17, 26, 50, 92-93, 104-105

Ivanishvili, Bidzina 94, 107

Joint Committee for Democratization and Conciliation (JCDC) 124

Kelman, Herbert 2, 19-20, 84

Khutsishvili, Giorgi 44, 46-50, 52

Korostelina, Karina 7

Kozaeva, Lira 41-43, 45-49, 52

Lakerbaia, Zurab 40-41

law on foreign agents, law on foreign partners 102

Lederach, John Paul 20, 31, 37

Lewin, Kurt 20, 27

Life and Peace Institute 132

local leadership, local context, local culture $6,39,81,83-89,130$

Lund, Michael 71, 75

Mampilly, Zachariah 18

Marks, Susan Collin 131

Mebuke, Manana 47-48, 52

Medvedev, Dmitry 14

Mitchell, Christopher R. 3, 20, 61

Moldova 55-56, 62, 124

Moldovan Initiative Committee on

Management (MICOM) 124

multi-track diplomacy 60-61, 102

Nagorno Karabakh 6, 93, 97

Narts 12

Naumkin, Vitaly 66-67

nested model of conflict 15, 19, 81, 86, 92 nested model of peacemaking 62-64

networked regionalism 113

networks, network society 116-20,

123-24, 126-27

Neu, Joyce 68

Ohanyan, Anna 113

Olson, Lara 4, 15, 26-27, 44, 89, 132

olympics $6,27,93,95$

opening dialogue 67-68

Organization for Security and

Cooperation in Europe (OSCE) 23, 38,76

Ossetian language 10-13, 51

peacemaking $1-8,10-11,15-23,28-29$, 32-33, 37-43, 51-57, 60-65, 73, 75-77, 81-99, 102-103, 108-10, 112-14, 117-20, 124, 127, 129-34

Phronesis, 18

Point of View 15, 28, 38, 40-41, 44, 48-51, 102-108, 110, 112, 115-18 post-liberal peace 3

Predein, Konstantin 52, 104

preventive diplomacy 71,75

problem-solving workshops, analytical problem-solving workshops $2-3,7$, 61,75

psychodynamic approach 2, 7, 70-71

Reflecting on Peace Practice (RPP) Matrix 105

reflective practice $5,21,24-25,29,31$, $84,105,130,134$

reflective praxis 18

Rice, R. Eugene 20

Richmond, Oliver 3, 85

Romano, Arthur 20, 64

Romanova, Ekaterina 4, 15, 44, 89

Rothbart, Daniel 18, 32-33

Rubenstein, Richard E. 18

Rugaragu, Innocent 40

Russian language 10-11, 87

Saakashvili, Mikhail 14, 50, 93-94, 107

Sanakoeva, Anna 48, 52

Sarkozy, Nicholas 14

Saunders, Harold 3, 38, 61, 66

scholar-practitioner 5, 19-20, 22, 29, $53,84-85$

scholarship of engagement, engaged scholarship 3, 5, 20-21, 22, 24, 31, 33,134 


\section{Index}

Schon, Donald 18, 24

Shevardnadze, Eduard 13, 54

Smith, Samantha 53, 75, 77

Susskind, Laurence 20

sustained dialogue 3,53

Tadevosyan, Margarita 4, 37, 53

Tagliavini, Heidi 14, 49

Tamada, 51

Tbilisi 4, 10, 32, 41, 45-46, 49, 54-55, 96, 104

Ter-Gabrielian, Gevork 121-122

theory and practice gap 5, 19

third party consultation 3

Tkhovrebov, Kazbulat 108

track one diplomacy 51, 60-61, 71, 75,102

track one-and-a-half diplomacy 51, 61 , $71,75,102$

track two diplomacy 60-61, 71, 75, 87,102

Transdniestria 4, 55-56, 62, 124 transitional space $65-66$

Tskhinvali 10, 41, 52, 90

Ury, William 68

US Agency for International

Development (USAID) 26-27, 40, 44,47

validity 31

Value of Dialogue 15, 53, 96, 103, 109-10

van der Stoel, Max 76

Volkan, Vamik 2, 70-74

Warfield, Wallace 20, 83

Wark, McKenzie 7

Zakareishvili, Paata 41, 44-45, 48-49, 54, 94, 107

Zonkari Dam 11, 16, 26, 52, 103, 105 